\title{
THE UREWERA NOTEBOOK: SCHOLARLY EDITION
}

By

ROSE ANNA O'RORKE PLUMRIDGE

\author{
A thesis \\ submitted to the Victoria University of Wellington \\ in fulfilment of the requirements for the degree of \\ Master of Arts in English Literature
}

Victoria University of Wellington

2014 
For Peter Whiteford

and

Elizabeth Plumridge 


\section{Contents}

$\begin{array}{ll}\text { Abstract } & 5\end{array}$

$\begin{array}{ll}\text { List of photographs } & 7\end{array}$

$\begin{array}{lr}\text { Acknowledgments } & 9\end{array}$

$\begin{array}{ll}\text { General Introduction } & 11\end{array}$

1. The role of the Urewera Notebook in Mansfield biography $\mathbf{1 1}$

2. Context to the 1907 camping trip $\quad \mathbf{1 5}$

i. $\quad$ Mansfield's personal background $\quad \mathbf{1 5}$

ii. Hawke's Bay and Kaingaroa $\quad 17$

iii. The Urewera $\quad \mathbf{1 8}$

iv. Rotorua and the geothermal district $\quad \mathbf{2 0}$

3. Rereading the Urewera Notebook 21

i. Mansfield's attitude to colonials $\quad 21$

ii. Mansfield's attitude to Maori $\quad \mathbf{2 5}$

iii. Mansfield's attitude to the landscape $\quad 29$

4. Conclusion 32

$\begin{array}{ll}\text { Textual Introduction } & 34\end{array}$

1. The Urewera Notebook: Physical description 34

2. Editorial history $\mathbf{3 5}$

3. John Middleton Murry: The Life of Katherine Mansfield (1933) and the 36 Journal of Katherine Mansfield 1904-1922: Definitive Edition (1954)

i. John Middleton Murry: Context 36

ii. John Middleton Murry: Editorial methods $\quad 37$

iii. John Middleton Murry: Contextual aids $\quad \mathbf{4 2}$

iv. John Middleton Murry: Critical reception $\mathbf{4 3}$

4. Ian A. Gordon: The Urewera Notebook (1978) 45

i. Ian A. Gordon: Context $\mathbf{4 5}$

ii. Ian A. Gordon: Editorial methods $\mathbf{4 6}$

iii. Ian A. Gordon: Contextual aids 47

iv. Ian A. Gordon: Critical reception 49 
5. Margaret Scott: The Katherine Mansfield Notebooks (1997) 50

i. Margaret Scott: Context

ii. Margaret Scott: Editorial methods $\quad \mathbf{5 2}$

iii. Margaret Scott: Contextual aids $\mathbf{5 3}$

iv. Margaret Scott: Critical reception $\mathbf{5 4}$

6. Conclusion $\quad \mathbf{5 4}$

Editorial Procedures $\quad 56$

Biographical Register of the Camping Party 59

$\begin{array}{ll}\text { Itinerary } & 62\end{array}$

1. Length of the camping trip

2. Description of events

$\begin{array}{ll}\text { Abbreviations in this Edition } & 77\end{array}$

The Urewera Notebook $\quad 82$

$\begin{array}{ll}\text { Bibliography } & 113\end{array}$ 


\section{$\underline{\text { Abstract }}$}

This thesis is a scholarly edition of Katherine Mansfield's Urewera Notebook. The General Introduction summarises the purpose to which the notebook has been put by previous editors and biographers, as evidence for Mansfield's happiness or unhappiness in New Zealand throughout 1906-8. It then offers an overview of the historical context in which the notebook was written, in order to demonstrate the social complexity and geographical diversity of the terrain that Mansfield covered during her 1907 camping holiday. This is followed by an analysis of Mansfield's attitudes towards colonials, Maori and the New Zealand landscape. Mansfield's notebook is permeated by a sense of disdain for colonials, especially when encountered as tourists, but also a fascination with 'back-block' settlers and a sense of camaraderie with her travelling companions. Mansfield repeatedly romanticised Maori as a noble 'dying race' with a mythic past, but was also insightfully observant of the predicament of Maori in contemporary colonial society. Her persistent references to European flora, fauna and 'high culture', and her delight in conventionally picturesque English gardens, reveal a certain disconnect from the New Zealand landscape, yet occasional vivid depictions of the country hint at a developing facility for evoking New Zealand through literature.

In the Textual Introduction I discuss the approaches of the three prior editors of the notebook: John Middleton Murry polished, and selectively reproduced, the Urewera Notebook, to depict Mansfield as an eloquent diarist; Ian A. Gordon rearranged his transcription and couched it within an historical commentary which was interspersed with subjective observation, to argue that Mansfield was an innate short story writer invigorated by her homeland. Margaret Scott was a technically faithful transcriber who provided accuracy at the level of sentence structure but whose minimal scholarly apparatus has made her edition of the notebook difficult to navigate, and has obscured what Mansfield wrote.

I have re-transcribed the notebook, deciphering many words and phrases differently from prior editors. The Editorial Procedures are intended as an improvement on the editorial methods of prior editors. The transcription itself is supported by a collation of all significant variant readings of prior editions. A running commentary describes the notebook's physical composition, identifies colonial and Maori people mentioned in the text, and explains ambiguous historical and literary allusions, native flora and fauna, and expressions in Te Reo Maori. The Itinerary uses historical documents to provide a factually accurate description of 
the route that Mansfield followed, and revises the itinerary suggested by Gordon in 1978. A biographical register explains the social background of the camping party.

This thesis is based on fresh archival research of primary history material in the Alexander Turnbull Library, legal land ownership documents at Archives New Zealand, historical newspapers and information from discussions with Warbrick and Bird family descendants.

A map sourced from the Turnbull Cartography Collection shows contemporary features and settlements, with the route of the camping party superimposed. Facsimiles of pages from the notebook are included to illustrate Mansfield's handwriting and idiosyncratic entries.

Photographs have been selected from Beauchamp family photograph albums at the Turnbull, from the Ebbett Papers at the Hawke's Bay Museum Theatre Gallery, and from private records. 


\section{List of photographs}

\section{Image 1: The Urewera Notebook}

Photographed by Elizabeth Plumridge, qMS-1244, John Middleton Murry Collection, Alexander Turnbull

Library, Wellington, N.Z.

Image 2: Internal pages of the Urewera Notebook, with torn stubs along the binding and folios hanging loose

Photographed by Elizabeth Plumridge, qMS-1244, John Middleton Murry Collection, Alexander Turnbull Library, Wellington, N.Z.

\section{Image 3: Folio 20 of the Urewera Notebook}

qMS-1244_020.tif, John Middleton Murry Collection, Alexander Turnbull Library, Wellington, N.Z.

\section{Image 4: Folio 81v of the Urewera Notebook}

qMS-1244_081a.tif, John Middleton Murry Collection, Alexander Turnbull Library, Wellington, N.Z.

Image 5: Katherine Mansfield in the garden of 47 Fitzherbert Terrace, 1907

PA1-o-789-11-2, Norwood Collection, Alexander Turnbull Library, Wellington, N.Z.

Image 6: Harold, Annie and Jeanne Beauchamp at 47 Fitzherbert Terrace, 1907

PA1-o-790-87-3, Norwood Collection, Alexander Turnbull Library, Wellington, N.Z.

Image 7: Annie and Charlotte 'Chaddie' Beauchamp at 47 Fitzherbert Terrace, 1907

Photographed by Elizabeth Plumridge, John Middleton Murry Collection, Alexander Turnbull Library,

Wellington, N.Z.

Image 8: The camping party at Eskdale

Photographed by Elizabeth Plumridge, John Middleton Murry Collection, Alexander Turnbull Library,

Wellington, N.Z.

Image 9: Te Pohue, or 'Bodleytown', with evidence of bush burnings in the background PA1-o-1006-24-1, John Middleton Murry Collection, Alexander Turnbull Library, Wellington, N.Z.

Image 10: Allowing the horses to graze along the Napier-Taupo Road

PA1-o-1006-23-1, John Middleton Murry Collection, Alexander Turnbull Library, Wellington, N.Z.

Image 11: The Waipunga Falls, along the Napier-Taupo Road

PA1-o-1006-26-2, John Middleton Murry Collection, Alexander Turnbull Library, Wellington, N.Z.

\section{Image 12: The Rangitaiki store and accommodation house, 1907}

Photographed by Elizabeth Plumridge, reproduced with permission of Marion Klaus, Rangitaiki Tavern, State Highway 5, Taupo

Image 13: The campers on the Kaingaroa Plains

PA1-o-1006-26-1, John Middleton Murry Collection, Alexander Turnbull Library, Wellington, N.Z.

Image 14: William Henry Bird and his wife Kiekie Hopaia

Photographed by Elizabeth Plumridge, reproduced with permission of Rita Teddy, Murupara 


\section{Image 15: The campers at the Galatea Station}

Photographed by Elizabeth Plumridge, John Middleton Murry Collection, Alexander Turnbull Library, Wellington, N.Z.

\section{Image 16: The camping party with local residents at Te Whaiti}

Photographed by Elizabeth Plumridge, John Middleton Murry Collection, Alexander Turnbull Library, Wellington, N.Z.

\section{Image 17: Unidentified man at Te Whaiti, 1907}

PA1-o-1006-31, John Middleton Murry Collection, Alexander Turnbull Library, Wellington, N.Z.

Image 18: The camping party returning from Ruatahuna to Te Whaiti

Photographed by Elizabeth Plumridge, John Middleton Murry Collection, Alexander Turnbull Library, Wellington, N.Z.

Image 19: The camping party stopping for lunch, possibly in the Urewera

PA1-o-1006-25-1, John Middleton Murry Collection, Alexander Turnbull Library, Wellington, N.Z.

Image 20: A photograph belonging to George Ebbett, taken at the Hamurana Spring near Rotorua, during the 'Round Trip'

Hamurana Spring, Rotorua, Frederick George Radcliffe (b.1863, d.1923), collection of Hawke's Bay Museums Trust, Ruawharo Tā-ū-rangi, 12579

Image 21: The mountain Pohaturoa, on the banks of the Waikato River

PA1-o-1006-27-1, John Middleton Murry Collection, Alexander Turnbull Library, Wellington, N.Z.

\section{Image 22: The camping party at the Aratiatia Rapids}

Photographed by Elizabeth Plumridge, John Middleton Murry Collection, Alexander Turnbull Library, Wellington, N.Z.

\section{Image 23: The Huka Falls}

PA1-o-1006-29-1, John Middleton Murry Collection, Alexander Turnbull Library, Wellington, N.Z.

Image 24: Runanga, the site that Mansfield later adopted as the scene of 'The Woman at the Store'

Photographed by Elizabeth Plumridge, John Middleton Murry Collection, Alexander Turnbull Library,

Wellington, N.Z.

Image 25: Map showing the campers' route

MapColl 830a/[1914?]/Acc.7379, Land Information New Zealand, Alexander Turnbull

Library, Wellington, N.Z. 


\section{Acknowledgments}

I owe a real debt of thanks to Vincent O'Sullivan, who encouraged me to undertake this research and took an ongoing interest in its development. I am also indebted to Sir Kenneth Keith and John Ross, donors of the D.F. McKenzie Award, for endorsing the importance of my work.

I am grateful to a number of people who responded to research queries, among them Kyle Bland, of GNS Science; Chris Johnson, of the Hastings District Council; Madelon Van Zijll De Jong, of the Hastings War Memorial Library; Noti Belshaw, of Te Runanga o Ngati Awa, and Te Waiti Rangiwai, of Te Runanga o Ngati Whare; Rawinia Higgins, of Victoria University; Te Haumihiata Mason, of the Maori Language Commission; Awhina Tamarapa, of Te Papa Tongarewa; Materoa Dodd, of the Maori Women's Welfare League; and John Webber and Jane Hayward, the grandchildren of Mansfield's camping companions, Herbert James and Elsie Webber.

A number of archivists and curators at museums throughout the country assisted my efforts to locate archival material, particularly Rohi Kaimarama, of the Whakatane Museum and Gallery, Ann Milton-Tee and Christine Page, of the Tairawhiti Museum, Gail Pope and Sarah Powell of the Hawke's Bay Museum Theatre Gallery, and the Alexander Turnbull Library staff.

Tina Ngaroimata-Fraser, of the University of Northern British Columbia, put me in touch with her family at Waiohau, and it was there that I had the pleasure of meeting Mate Tihema, Maudy Tupe and the others at Te Tapenakara o te Iwi, whose hospitality was most gracious.

I am immensely grateful to Paerau Warbrick, of the University of Otago, for responding so graciously to queries about his whakapapa, and for identifying Albert Warbrick, Heeni Poraka and Joanna Hill Kaua.

Another group of people deserve special mention. Pem Bird, the principal of Te Kura Kaupapa Motuhake o Tawhiuau, made field work in Murupara possible, introduced me to local kaumatua, and together with Wai Murphy, extended the warmest hospitality. It was an honour to meet Rita Teddy, Henry (Boy) Nuku, Queenie Nuku and Bert Messent, the kaumatua of Ngati Manawa who gave up a great deal of time to discuss family and regional 
history, and to show me the route that Katherine Mansfield took as she travelled through Ngati Manawa lands.

To my supervisor, Peter Whiteford, I offer my esteem and gratitude. 


\section{General Introduction}

\section{The role of the Urewera Notebook in Mansfield biography}

The year before her death, Katherine Mansfield made a will in which she declared, 'I desire to leave as few traces of my camping ground as possible'. ${ }^{1}$ This strikingly lyrical metaphor, in an otherwise prosaic legal document, resonates of real events in Mansfield's youth. In 1907 she joined a party of campers on a tour of the North Island of New Zealand. It was a holiday planned by a Hastings solicitor, George Ebbett, and the party comprised predominantly his colonial, middle-class acquaintances: his wife Maud, a Hastings chemist Herbert Webber and his wife Elsie, and Annie Leithead, whose father ran a large Hawke's Bay station. Mr Hill, a Hastings famer, had been contracted to help drive the horse-drawn luggage waggon, and an invitation had also been extended to Ebbett's cousin in Wellington, Millie Parker. ${ }^{2}$ Millie knew Mansfield through musical networks, and helped to secure for her friend a place in the camping party. The two young women travelled by train to Hastings, where they joined the others, and began a circuit that led them along the Napier-Taupo Road, took them briefly into the Urewera, and passed through the thermal district around Rotorua and Taupo. ${ }^{3}$ That the experience was one of life-long significance is suggested by the expressive phrase in Mansfield's last will and testament.

At the outset of the camping trip, Mansfield began filling a journal now commonly referred to as the Urewera Notebook. ${ }^{4}$ If this notebook is known to the world at all, it is probably as the personal diary from which Mansfield sourced material for her more well-known story 'The Woman at the Store' (1912). However this small, shabby, inconspicuous-looking document holds considerable significance in its own right, as the only extant manuscript in which Mansfield explores and records her country of birth beyond the boundaries of provincial Wellington. At the time of the camping holiday Mansfield was in a state of limbo: in December 1906 she had returned to Wellington after three years' schooling in London but throughout 1907 she yearned to return to England, and before the end of 1908 she had succeeded: this departure was to be final, for although she returned to the colony repeatedly in her fiction, she never again returned in person. The Urewera Notebook has therefore

\footnotetext{
${ }^{1}$ Wellington, Alexander Turnbull Library, MS-Papers-7224-06, Will of Katherine Mansfield Murry.

${ }^{2}$ See Biographical Register p. 59.

${ }^{3}$ See Itinerary p. 62.

${ }^{4}$ This name was given to the notebook by Ian A. Gordon in 1978.
} 
additional value as evidence of Mansfield's attitudes to New Zealand, not in adulthood when memory is tempered by time, or in fiction where memory is reworked through the act of writing, but as a nineteen year old living in the colony.

Numerous popular biographies of Mansfield have examined the camping notes, and several editors have published them in print editions. Yet the fact remains that for most of its life the Urewera Notebook has been undervalued, under-examined and poorly understood. When collaborating on the biography The Life of Katherine Mansfield (1933), American scholar, Ruth Mantz, and Mansfield's husband, John Middleton Murry, set the tone of the discussion of the notebook for the following forty years. Mantz and Murry depicted the camping holiday as a journey into 'another epoch' (pp. 306-7) of New Zealand history, where Maori were 'primitive' and unspoiled, and the bush pristine: ${ }^{5}$ while traversing a land of 'strange magic' (p. 303) Mansfield witnessed 'Maoris in their native pahs - living much the life they must have lived when The True Original Pa Man pioneered in New Zealand' (p. 289) and gazed on 'wild beauty ... so little spoiled ... by white settlers' (p. 302). ${ }^{6}$ While Mansfield enjoyed temporary 'peace' (p. 303) in this almost mythic landscape, the experience they said made her 'even more restless in Wellington, even more at odds with her immediate surroundings' (p. 308). The 'Mantz portrait', as it has come to be called, ${ }^{7}$ harnessed the Urewera Notebook to the argument that Mansfield's relationship with New Zealand during 1906-1908 was generally 'bitter' (p. 301) and characterised by fervent 'resentment' (p. 314).

This interpretation of the notebook proved persuasive, and in the following four decades biographies repeated it. In 1951 Sylvia Berkman reiterated that the camping trip showed Mansfield how 'Maori natives lived in their pahs scarcely touched by civilization' amid 'the wild luxuriance of nature', and that although the experience 'provided [a] momentary peace', inevitably 'the return to Wellington brought reaction'. ${ }^{8}$ In 1954 Antony Alpers echoed the same theme: the camping trip revealed to Mansfield 'the Maori in his natural dignity' and the 'wild, untamed beauty of her country', but it 'only made Kathleen more certain than ever of her need to get away'. ${ }^{9}$ In 1978 Jeffrey Meyers again rehearsed the familiar line that the 'trip

\footnotetext{
${ }^{5}$ Ruth Elvish Mantz and John Middleton Murry, The Life of Katherine Mansfield (London: Constable, 1993), pp. 306-7.

${ }^{6}$ For an explanation of 'Pa-man',see MS-Papers-4026, 1.9.

${ }^{7}$ Katherine Mansfield, The Urewera Notebook, ed. by Ian A. Gordon (Christchurch: Oxford University Press, 1978).

${ }^{8}$ Sylvia Berkman, Katherine Mansfield: A Critical Study (New Haven, CN: Yale University Press, 1951), pp. 30-1.

${ }^{9}$ Antony Alpers, Katherine Mansfield: A Biography (London: Cape, 1954), p. 94.
} 
to the Ureweras introduced Katherine to the gentle ways of the primitive Maori ... to the wild natural beauty of North Island, and to the conditions her grandfather and father had found when they came to New Zealand in the 1860s'. But although 'Katherine had enjoyed her trip, she was still eager to return to London' ${ }^{\prime 10}$ to escape the 'tyranny' and 'inferiority' of her Wellington circle. ${ }^{11}$

The 'Mantz portrait' was contested for the first time by Victoria University Professor Ian A. Gordon. In a new edition of the Urewera Notebook in 1978, Gordon argued for an alternative point of view, claiming Mansfield was no 'unhappy young woman ... on her return to New Zealand'. He maintained instead that the Urewera Notebook revealed a young woman 'vigorously enjoying herself' (p. 19). Gordon's evidence was based less on an analysis of Mansfield's attitudes to the terrain she covered or the people she met, than on intermittent allusions in the notebook to herself as 'happy - blissfully happy' (1. 657-8). He argued that Mansfield led an active social and intellectual life upon her return to Wellington: after 'bouncing back from the Urewera adventure' (p. 20) she 'swam ... went walking ... went to the theatre ... holidayed with her sister Chaddie at Day's Bay ... engaged in summertime tennis parties at the family home' (p. 23). In the 'Gordon portrait' the Urewera Notebook served as evidence that Mansfield led a happy life in New Zealand of 'quite orthodox normality’ (p. 24).

Biographies in the wake of Gordon's scholarship only partly accepted his argument. In 1987 Claire Tomalin described the camping holiday as 'too interesting and arduous for Katherine to do anything but enjoy herself', ${ }^{12}$ but also asserted that 'fluctuation between cold hostility to the family and warm enjoyment of some aspects of its luxurious way of life was part of Katherine's experience in 1907'. ${ }^{13}$ In 1997 librarian Margaret Scott undertook to transcribe the notebook afresh. She accepted that Gordon's reading had been valid: 'Professor Ian Gordon' she wrote in her autobiography, 'was the first to point out that the picture of the wretchedly unhappy adolescent was false. In the manuscript she says things like 'we laugh with joy all day' and 'we are blissfully happy'. ${ }^{14}$ However, in her 2013 biography, Kathleen Jones said of Mansfield's experience: 'though the wildness and savagery of the landscape strike a chord in her own passionate nature, Katherine is always aware of her longing to be

\footnotetext{
${ }^{10}$ Jeffrey Meyers, Katherine Mansfield: A Biography (London: Hamish Hamilton, 1978), p. 35.

${ }^{11}$ Meyers, p. 21.

${ }^{12}$ Claire Tomalin, Katherine Mansfield: A Secret Life (London: Viking, 1987), pp. 41-2.

${ }^{13}$ Tomalin, p. 32.

${ }^{14}$ Margaret Scott, Recollecting Mansfield (Auckland: Godwit, 2001), pp. 155-6.
} 
somewhere else', ${ }^{15}$ and throughout the trip, '[h]er emotions swing wildly between ecstasy and despair". ${ }^{16}$

This pendulum of popular debate has swung back and forth, but always within its narrow ambit: Mansfield's biographers and editors have successively cast the Urewera Notebook as evidence of Mansfield's contentment or discontentment in New Zealand, in a polemic which, although not uninteresting, has constrained readers' appreciation of the complexity of Mansfield's character. In recent decades scholars have begun to broaden the scope of academic debate around the Urewera Notebook: Mark Williams and Jane Stafford have considered it within the context of the 'Maoriland literature' of late nineteenth and early twentieth century New Zealand in Maoriland: New Zealand Literature 1872-1914. ${ }^{17}$ Paul Moon has used it to consider how white colonials situated Maori as 'the unfamiliar Other' in his history of New Zealand's changing national identity, Encounters: The Creation of New Zealand, A History. ${ }^{18}$ Non-New Zealand commentators have used the notebook in postcolonial studies and travel writing: in Prose of the World: Modernism and the Banality of Empire, Saikat Majumdar has included the notebook in his examination of modernist writers who explore the concept of 'banality' in the colonial periphery. ${ }^{19}$ Anne Maxwell has read the notebook as an example of a particular kind of travel writing of the modernist period 'associated with the cultivation of aesthetic taste and with the preservation of high culture'. ${ }^{20}$ But re-readings have had to rely on editions of the notebook which have been geared, not to expand debate, but to prove a particular point of view about Mansfield's cheerless or contented mental state in 1907.

This edition aims to follow Janet Wilson's precedent of an 'historicised' and an 'empirical approach' to Mansfield studies, ${ }^{21}$ by reconsidering the Urewera Notebook within its historical and social context, to focus anew on how Mansfield can be understood through her camping notes. The country that Mansfield traversed in 1907 was one of significant regional variation

\footnotetext{
${ }^{15}$ Kathleen Jones, Katherine Mansfield: The Story-teller (Auckland: Viking, 2010), p. 77.

${ }^{16}$ Jones, pp. 66-67.

${ }^{17}$ Jane Stafford and Mark Williams, Maoriland: New Zealand Literature 1872-1914 (Wellington: Victoria University Press, 2006).

${ }^{18}$ Paul Moon, Encounters: The Creation of New Zealand: A History (Auckland: Penguin, 2013) pp. 219-20.

${ }^{19}$ Saikat Majumdar, Prose of the World: Modernism and the Banality of Empire (New York: Columbia University Press, 2013), p. 92.

${ }^{20}$ Anne Maxwell 'A Young Writer's Journey into the New Zealand Interior: Katherine Mansfield's The Urewera Notebook', in Travel Writing in the Nineteenth Century: Filling the Blank Spaces, ed. by Tim Youngs (Singapore: Anthem Press, 2006), pp. 219-236.

${ }^{21}$ Janet Wilson, and others, eds, Katherine Mansfield and Literary Modernism (London: Continuum, 2011), p. vii.
} 
with highly localised histories of Maori-Pakeha relations and environmental change. The attitudes that Mansfield expresses over the course of her journey towards colonial New Zealanders, indigenous Maori, and to the landscape itself, show her at times sympathetic to her colonial upbringing and at other times at odds with it. Reconsidering the Urewera Notebook in this light suggests that Mansfield was inhabiting different mental, as well as physical, worlds as she journeyed across the North Island, and proves remarkably apposite the metaphor of 'camping' to describe her brief, peripatetic existence.

\section{Context to the 1907 camping trip}

\section{i. Mansfield's personal background}

To obtain a more complete understanding of the Urewera Notebook, it is necessary to consider the attitudes and presumptions that Mansfield took with her as she left Wellington for the central North Island. Vincent O'Sullivan has described Mansfield as born into 'a family, and a country, constantly checking themselves in a mirror: so much of their reality had to do with how 'Britain' was reflected in their values and assumptions'. ${ }^{22}$ Mansfield occupied the higher rungs of a colonial society which saw itself as playing a loyal role in the 'vast enterprise of Empire', ${ }^{23}$ but boasted of its local achievements, and showed signs of an independent sense of history. ${ }^{24}$ When considering Mansfield's response to colonials in the Urewera Notebook, it is important to acknowledge that her own family afforded her access to a British education and elite colonial networks: Harold Beauchamp counted Richard Seddon, New Zealand's Premier, as one of his 'close friends', ${ }^{25}$ while Seddon's children formed part of the Beauchamp girls' social scene. It is important to realise that Mansfield was primed to respect European 'high culture', while also taking an interest in Maori society. Margaret Werry has said of Mansfield's society that it 'paired progressive liberalism with Maori culture at the forefront of diplomatic pageantry, nationalist historiography, and artistic production as the coin of national distinction' ${ }^{26}$ It is perhaps not surprising therefore that Mansfield's own family regarded Maori society with interest. Marion Ruddick, a childhood friend of Mansfield, remembered Beauchamp's partly ethnographic interest in Maori culture:

\footnotetext{
${ }^{22}$ Katherine Mansfield, New Zealand Stories, ed. by Vincent O’Sullivan (Auckland: Oxford University Press, 1997), p. 1.

${ }^{23}$ Ibid.

${ }^{24}$ Michael King, The Penguin History of New Zealand (Auckland: Penguin, 2003), pp. 281-2.

${ }^{25}$ Harold Beauchamp, Reminiscences and Recollections (New Plymouth, NZ: T. Avery, 1937), pp. 72.

${ }^{26}$ Margaret Werry, The Tourist State: Performing Leisure, Liberalism, and Race in New Zealand (Minneapolis: Quadrant, 2001), pp. xi-xii.
} 
he 'said the maoris were so chivalrous that, before attacking enemy whites, they would send them food and ammunition, then fight them with weapons made of bone, stone and the hard greenstone'. ${ }^{27}$ Ruddick also recalled that Beauchamp 'liked to talk about the Maoris and knew many of their words and phrases'. ${ }^{28}$

Not only was Mansfield was brought up to have some admiration for ancient Maori, but she was also accustomed to a Maori presence in her own privileged social world. The same social column in in the Free Lance that reported Lady Ward's 'farewell' for Mansfield on the eve of her departure for England in 1908, also described Mrs (later Lady) Pomare's participation in the 'Hutt Cinderella' dances; ${ }^{29}$ the Beauchamp girls attended the same Racing Club Balls as the Pomares ${ }^{30}$ the movements of Harold Beauchamp and Dr Maui Pomare were tracked in the same social columns. ${ }^{31}$ Mansfield also knew some Maori personally: her relationship with the wealthy Maata Mahupuku has been well-documented. It is important to acknowledge that these were a particular type of Maori, well integrated into colonial European society and arguably distanced from their Maori roots. Eric Ramsden, who had a close rapport with Waikato Maori leaders, and whose home became a 'base for a large number of tribal and national Maori leaders ... when government business brought them to the capital', 32 said of Maata, for instance:

Maori people never had much time for her. [She] was educated above their standard, always had expensive and cultured tastes, and could have little in common with them. If she had any knowledge of Maori it can only be fragmentary. The other Maoris always considered her a Pakeha in outlook and ways. I do not thin[k] she did anything to help her people or in any way benefit them ... [She] seems to have led a useless, selfish existence, and in no sense do the Maoris consider her one of them. ${ }^{33}$

\footnotetext{
${ }^{27}$ Wellington, Alexander Turnbull Library, MS-Papers-1339, Marion C. Ruddick 'Incidents in the Childhood of Katherine Mansfield', p. 65.

${ }^{28}$ MS-Papers-1339, p. 66.

${ }^{29}$ Free Lance, 4 July 1908 , p. 8.

${ }^{30}$ Evening Post, 24 July 1908, p. 2.

${ }^{31}$ Dominion, 24 June 1908, p. 6.

${ }^{32}$ Michael King. 'Ramsden, George Eric Oakes', in Te Ara, The Encyclopedia of New Zealand <http://www.TeAra.govt.nz/en/biographies/4r1/ramsden-george-eric-oakes> [accessed 14 January 2014].

${ }^{33}$ Wellington, Alexander Turnbull Library, MS-Papers-6498, Eric Ramsden to Pat Lawlor, 1949.
} 
But if Mansfield's Wellington world has been given significant scholarly attention, the places she traversed on the camping trip have received almost no analysis. Although in 1907 she covered a relatively confined area, it was one of complex variation, regional 'contact zones' as Pratt has termed them, in which Maori iwi and hapu had sought different ways of responding to a European presence, 'within radically asymmetrical relations of power' ${ }^{34}$ Tracing Mansfield's nuanced responses to and awareness of regional variations, of which the Urewera was but one part, indicates the kind of woman, colonial and writer-in-training that Mansfield then was.

\section{ii. Hawke's Bay and Kaingaroa}

The resistance of Pai Marire to government forces and 'loyalist' Maori at Petane and Omaunui in 1866 resulted in government confiscation of 295,000 acres of Maori land in the Hawke's Bay. Most of the area that Mansfield travelled along the Napier-Taupo Road was within the boundaries of this 1867 confiscation and while some land had been returned to Maori (not necessarily to the original owners), much was retained by the Crown and leased out as vast pastoral stations. ${ }^{35} \mathrm{In}$ and around the confiscation district were areas of original bush around which a large milling industry had built up, starting at Te Pohue in 1900. In the Hawke's Bay, Maori were involved in the region's pastoral economy or in milling, working seasonally as 'general labourers and shearers', or 'in bush work for settlers, cutting timber for buildings, fencing, and firewood, and in clearing bush for farming, ${ }^{36}$

The Kaingaroa section of the Napier-Taupo Road was a sharp contrast to this. Vast areas of this dusty pumice tract had been in Crown ownership since 1877, and although the government had purchased the plain intending it for settlement, the area was still deserted in 1907: settlers avoided pumice country which 'had a bad reputation for farming' and even the 'Department of Agriculture warned against ... the pumice country ... as a useless wasteland'. ${ }^{37}$ The camping party did not even have a road to guide their traverse. Elsie Webber recalled many years later that '[a]fter leaving Pohui, we met very few people'. ${ }^{38}$ The few Pakeha people that they did encounter were employed on maintaining the roads (the

\footnotetext{
${ }^{34}$ Mary Louise Pratt, Imperial Eyes: Travel Writing and Transculturation (London and New York: Routledge, 2008), p. 7-8).

35 Waitangi Tribunal, The Mohaka ki Ahuriri Report (Wai 201, 2004) 2, pp. 639-682.

36 Ibid.

${ }^{37}$ Joan Boyd, Pumice and Pines: The Story of the Kaingaroa Forest (Wellington: GP Publications, 1992), pp. 910.

${ }^{38}$ Wellington, Alexander Turnbull Library, MS-Papers-4010, Elsie Webber to Henry Graydon Cook, 20 February 1956.
} 
Himing family, for instance), or servicing the needs of travellers through the region ( $\mathrm{Mr}$ Bodley at Te Pohue).

\section{iii. The Urewera}

Due to its rugged impenetrability, the Urewera had been one of the last areas of colonial encroachment. Its inhabitants, 'distinct but connected' hapu generally known as Tuhoe, ${ }^{39}$ had had little to do with Pakeha until the 1860s, and then contact proved disastrous for the iwi. After suffering 'starvation, deprivation and atrocities', 'scorched-earth' raids by government forces and crippling land confiscations ${ }^{40}$ the people of the Urewera did their best to maintain a 'voluntary sequestration'. Urewera leaders banned 'roads, surveys, land sales, leases and mineral prospecting', and for a time at least, government officials 'formally recognised' the area's regional autonomy. ${ }^{41}$ This history meant Tuhoe were frequently typecast by Europeans in the late nineteenth century as a fierce, untamed race. As Binney has said, 'the colonialist myth of Empire - an assumed right to authoritative control by Europeans - turned Te Urewera into New Zealand's 'Heart of Darkness'. The land was primordial and menacing, not able to be easily ordered by an axe, and its people 'primitive'" ${ }^{42}$

But by the time Mansfield visited the Urewera, matters had changed. The Urewera District Native Reserve Act 1896 had launched a process of individualisation of land title so that by the early twentieth century the government had begun surveying the area. ${ }^{43}$ Boast has suggested that Tuhoe did want

roads and schools. They hoped to benefit from tourism, and asked for introduced birds and fish to supplant their own diet and as a means of inducing tourists to visit the area. The leaders of Te Urewera were looking to the future and hoped to enter into a partnership with the Government to protect their region but also to develop and modernise it. $^{44}$

\footnotetext{
${ }^{39}$ Richard Boast, Buying the Land, Selling the Land: Governments and Maori Land in the North Island 1865 1921 (Wellington: Victoria University Press and Victoria University of Wellington Law Review, 2008), p. 202.

${ }^{40}$ Rangi McGarvey, 'Ngai Tuhoe', in Te Ara, The Encyclopedia of New Zealand $<$ http//www.TeAra.govt.nz/en.ngai-tuhoe.> [accessed on 16 April 2014].

${ }^{41}$ Boast, p. 202. Subsequent governments left Te Urewera alone simply because 'there was no pressure on the Government to open up the region at the time', See Boast p. 203.

${ }^{42}$ Judith Binney, Encircled Lands: Te Urewera, 1820-1921 (Wellington: Bridget Williams Books, 2009), p. 30.

${ }^{43}$ Boast, p. 207.

${ }^{44}$ Ibid.
} 
There is evidence this was so: a large 'model fighting pa' with a 'stockade with great posts carved in the semblance of human figures', ${ }^{45}$ had been erected at Mataatua in 1906 to encourage tourists to the region, although the poor quality roads meant that few came. ${ }^{46}$ It seems that by the early twentieth century, Pakeha penetration into the Urewera was not unusual: in 1904 Lord Ranfurly had come on a formal state visit as Governor. ${ }^{47}$ Mansfield's future brother-in-law, James Mackintosh Bell, made a trip through the Urewera and recorded his experience in a memoir, The Wilds of Maoriland (1914). Guide books were describing the region for tourists' benefit, and contemporary newspapers fairly frequently ran columns from private parties giving accounts of their holidays in the 'erstwhile terra incognita'. 48

Nevertheless, in 1907 race relations remained fractious. The same year that Mansfield toured the area, Rua Kenana established a religious community at Maungapohato. He was viewed by the government as a subversive threat and legislation had been passed with the "express intention of checking Rua's activities and imprisoning him'. ${ }^{49}$ The slow influx of Europeans did not benefit Tuhoe. Binney says this was a time of 'growing social and demographic disaster' for Tuhoe. ${ }^{50}$ The people were wretchedly poor and had experienced heavy crop losses. Food shortages and measles epidemics had introduced famine and 'excessive morbidity' into the Urewera. Government records for 1906 register the abysmal state of affairs:

...the people live practically upon potatoes, very often without any addition thereto save a little puwha, or the undeveloped fronds of Asplenium bidbijerum. These inland people are also addicted to ... rotten corn and 'turned' meat also ... And skin diseases are ever present. $^{51}$

The schoolchildren peering into the camera alongside the smiling camping party at Te Whaiti were probably living 'solely on potatoes and cress, with only two meals a day'. ${ }^{52}$ The Te Whaiti School Attendance Register for 1907 leaves a sorry record, not only of the children's

\footnotetext{
45 James Cowan, New Zealand or Ao-tea-roa: Wealth and Resources, Scenery, Travel-Routes, Spas, and Sport (Wellington: John Mackay, Government Printer, 1908) p. 178.

46 Binney, p. 508.

${ }^{47}$ Binney, pp. 402-3.

48 'Through Tuhoeland', Auckland Star, 25 February 1899, p. 1.

${ }^{49}$ Binney, p. 517.

${ }^{50}$ Binney, p. 433.

${ }^{51}$ Appendices to the Journals of the House of Representatives, 1906, I H-31, pp. 1-94 (p. 76 ).

52 Binney, p. 629.
} 
hardship, but community disasters. The school had closed during the whole month of August as measles swept through the population, and even in 'healthy' periods, and around the time Mansfield visited the register notes falling attendances for distressing reasons: 'no food' and 'school closed only four children came wet through'.53

\section{iv. Rotorua and the geothermal district}

By 1907, Rotorua had long been the site of a thriving tourist industry. Tourists were attracted to the region because of its 'alarming nearness to the underworld' (a plethora of exotic boiling springs and unpredictable geysers), and also because of the "charm of Maori domestic life' on show: women cooking in the steam and children bathing in the hot lakes. ${ }^{54}$ Up until the 1880 s, the tourist trade was run largely by local Arawa, some of whom were made 'very wealthy, at least by Maori standards', ${ }^{55}$ In 1884, for instance, it was reported that 1250 visitors had travelled to the Rotorua region, spending an estimated $£ 15,400$ on coach fares, guides and hotels. ${ }^{56}$ Unwilling to allow this commerce to stay under Maori control, in the early 1880s the Crown moved decisively to secure land titles at Rotorua: by 1900 the Government was the principal landowner in the region and had brought the tourist industry largely under its authority. Maori still benefited from the industry by working as guides, performers and as guardians of a few remaining thermal wonders. But on the whole they no longer controlled tourism.

By the time Mansfield visited it, Seddon's Government had commenced the programme to construct a world-class spa at Rotorua on the model of Cheltenham or Bad Worishofen. By 1907, Rotorua had a Government Sanatorium and a massive mock-Tudor bathhouse was under construction within the ground of the Government Gardens. The Crown had also acquired much the Maori village of Whakarewarewa, although the central area with its geysers and mud holes, still remained in Maori hands and there were a 'myriad petty disputes over tolls, rights of access, and using the pools for cooking and washing clothes' $:^{57}$ the inhabitants naturally wanted to retain some benefits of tourism while also carrying out their traditional lifestyle, while the Government sought to develop the Maori village as a state-run

\footnotetext{
${ }^{53}$ Department of Education, Northern Regional Office (BAAA), Maori Schools - Register of Daily Attendance Te Whaiti, Series 1006, Archives New Zealand, (ANZ).

${ }^{54}$ Margaret McClure, The Wonder Country: Making New Zealand Tourism (Auckland: Auckland University

Press, 2004), pp. 10-12.

55 Boast, p. 265.

56 See Vincent O’Malley and David Anderson Armstrong, The Beating Heart: A Political and Socio-economic History of Te Arawa (Wellington: Huia, 2008), p. 186.

57 Boast, p. 268.
} 
tourist 'showcase'. By 1907 the Tourist Department had begun building a highly sanitised 'model pa' at Whakarewarewa, with government employee Alfred Warbrick overseeing operations. ${ }^{58}$ In the process they had levelled a real pa, 'Tutanekai's ancient fortress at Te Rotowhio'.59

In response to the tourist potential of Rotorua, a body of travel writing literature arose with a set of thematic trends: as Wevers has pointed out, many visitors to New Zealand 'did not travel further south than Rotorua', ${ }^{60}$ and travel writing of the period continually recycled stereotypes of Rotorua Maori as degenerate and 'extortionate'. ${ }^{61}$ One of the key themes of New Zealand travel literature of this period was disappointment that Rotorua Maori were not the 'noble savage', that Rotorua Maori were acclimatised to the European presence and expected tourists to pay for the privilege of gazing upon them. As one visitor lamented, Maori in Rotorua 'cannot help being spoiled a little ... by Europeans'. ${ }^{62}$ James Cowan wrote in a government tourist book, 'most Maori villages have lost much of their picturesqueness under the touch of civilisation'. ${ }^{63}$ Mansfield's brother-in-law, James MacKintosh Bell, was disdainful: 'the Maoris ... have degenerated ... One sees him at his worst around the tourist resorts of the Hot Lakes District. ${ }^{64}$ Always, however, tourists wanted tours, hotels and up-todate amenities, but complained that Maori in the government town were debased from some earlier 'uncorrupted real state' ${ }^{65}$ This then was the diverse country where Mansfield encountered colonials, Maori and landscapes that were unprecedented in her experience, and were to provoke a complex set of reactions.

\section{Re-reading the Urewera Notebook}

\section{i. Mansfield's attitude to Colonials}

The Urewera Notebook is permeated by an undercurrent of disdain for things 'colonial'. It contains evidence even of flagrant prejudice: after encountering the English clergyman Charles Prodgers midway through her trip, Mansfield distinguished, and elevated, the genuine Englishman from the commonplace colonial in her notebook, 'it is splendid to see

\footnotetext{
${ }^{58}$ See 1. 195.

${ }^{59}$ Boast, p. 268.

${ }^{60}$ Lydia Wevers, Country of Writing: Travel Writing and New Zealand 1809-1900 (Auckland: Auckland University Press, 2002), p. 187.

${ }^{61}$ Wevers, p. 199.

${ }^{62}$ E. Way Elkington, Adrift in New Zealand (London: John Murray, 1906), p. 98.

${ }^{63}$ Cowan, p. 126.

${ }^{64}$ James Mackintosh Bell, The Wilds of Maoriland (London: Macmillan, 1914), pp. 109-10.

${ }^{65}$ Wevers, p. 200.
} 
once again - real English people - I am so tired \& sick of the third rate article' (11. 278-9). But Mansfield's disdain is also shown as a subtle superciliousness: she declined to eat 'morning lunch' on the train ride from Wellington, finding distasteful, or at least banal, the 'inevitable tea of the New Zealander' (11. 33-4). There is evidence that Mansfield's travelling companions sometimes detected an air of condescension about her. Elsie Webber later wrote: 'I recall on one occasion after K.B. had made a witty remark, my husband capping it with a quotation from Goethe.' Elsie recognised that Mansfield was 'a little surprised' to learn that Herbert Webber had any knowledge of Goethe and 'high culture'; it caused her 'a moment's hesitation' and provoked the slightly stunned response, "I see - a man of parts". ${ }^{6}$

But to conclude as some biographers have done that Mansfield was uniformly dismissive of colonial society, seeing in the 'rough, unpolished, materialistic, equalitarian colonial ... nothing but a threat to her ambition', is to overlook the fact that colonial society had its complexity, and that Mansfield's attitudes to it were complex. ${ }^{67}$ Mansfield's fellow campers unanimously found her likeable, convivial, and graced with an appropriate degree of humility. Elsie Webber thought that Mansfield was 'bright and vivacious and proved to be very good company'. ${ }^{68}$ She also said,

I do not think that Ruth Mantz in her biography of K.M. was quite correct in saying that K.B. disliked the people she was associated with in the camping party. It is now common knowledge that K.B. was going through an unhappy period when she took the trip. But to me, she gave no sign of being unhappy ... I was one of the youngest members of the camping party, and her confidences to me, her general demeanour ... do not suggest that she disliked me ... My husband and I liked her very much. ${ }^{69}$

Elsie Webber also recalled that when the younger members of the party failed to help with the dinner preparations on the first night of the trip, Mansfield revealed her privileged upbringing by admitting that she had 'never even made a pot of tea', but 'looked contrite' and thereafter always 'did [her] share' of the tasks. ${ }^{70}$ George Ebbett also thought 'Miss

\footnotetext{
${ }^{66}$ MS-Papers-4010.

${ }^{67}$ Alpers, p. 94.

${ }^{68}$ MS-Papers-4010.

${ }^{69}$ MS-Papers-4010.

${ }^{70}$ Ibid.
} 
Beauchamp was a very agreeable girl, we all liked her \& being town bred and never having slept in a tent before and never having seen Maoris living as they did then she was intensely interested and I think enjoyed herself immensely'. ${ }^{71}$ Gordon pointed out that Mansfield often commented on the campers' shared pleasure in the trip and each other's company: observations such as 'We laugh with joy all day' (1. 113) and 'hot - happy - blissfully happy - We sleep - in the tent' (11. 657-8) certainly suggest a sense of comradeship and camaraderie.

Yet Mansfield encountered 'the colonial' not only by way of the other campers: she also encountered 'colonial' New Zealand as manifest in the 'government town' of Rotorua. It is important also to consider why Mansfield so hated Rotorua. Many have attributed her misery and physical discomfort to the 'rotten egg smell' that haunts the town, ${ }^{72}$ and Mansfield noted, writing of herself in the third person, 'the nearer they get to the town the more she hates it perhaps it is smell' (11. 358-9). Certainly Mansfield did feel physically sick in Rotorua ('so ill - so tired - her headache is most violent' (11. 377-8)), but her most insistent complaint in the town was not the smell, but its tourist atmosphere. Her objection to Whakarewarewa was the ugliness: 'ugly suburban houses - ugly streets old shaking buses' (1.360). She resented the 'crowds of the veiled tourists' (11. 361) and disliked the infrastructure built up by the government to cater to tourists: the government sanatorium gardens she found 'horrid' (1. $365)$ and the government organised tourist trip she considered 'loathsome' (1.365). The sightseers themselves she found abhorrent: 'I confess, frankly that I hate going trips with a party of tourists - they spoil half my pleasure' (11. 405-6).

Yet in her disdain for the vulgarity of the tourist hordes, Mansfield was not alone; by 1907 many published travel writers were condemning them. James Buzard has noted that 'scores of passages in nineteenth-century travel-writing comment disdainfully on tourists' conspicuous failures of taste', ${ }^{73}$ and Wevers has discussed how 'most travel writers [had] a low opinion of other tourists' ${ }^{74}$ Away from Rotorua, Mansfield's party seem to have conceived of themselves as 'travellers' in contradistinction to 'tourists'. Millie in later years remembered her camping companions described themselves as 'travelling gypsies' rather than tourists. ${ }^{75}$

\footnotetext{
${ }^{71}$ Wellington, Alexander Turnbull Library, MS-Papers-7293-12, George Ebbett to P A Lawlor, 3 March 1957.

${ }^{72}$ Mansfield, The Urewera Notebook, ed. by Ian A. Gordon, p. 20.

73 James Buzard, 'The Grand Tour and After, 1660-1840', in The Cambridge Companion to Travel Writing, ed. by Peter Hulme and Tim Youngs (Cambridge UK; New York: Cambridge University Press, 2002), p. 60.

${ }^{74}$ Wevers, p. 165.

${ }^{75}$ Margaret A. Parker, 'A Summer Day in 1907', New Zealand Herald, 4 April 1931 p.6.
} 
Mansfield's regard for the Reverend Prodgers in the Urewera may owe something to this preference for travellers over tourists. Buzard has written of how 'travellers' saw themselves as experiencing "the authentic "culture" of places ... lurking in the secret precincts "off the beaten track" where it could be discovered only by the sensitive traveller, not the vulgar tourist' ${ }^{76}$ It is possible that Prodgers was 'splendid' in Mansfield's opinion, not only because he was English, but because he had eschewed Rotorua for the Urewera, which was at the very edges of European colonial expansion.

Mansfield and her travelling companions also encountered 'backblock' settlers, particularly along the Napier-Taupo Road. In the notebook Mansfield generally captured their essence to her in a few words: 'Mr Bodley - a great pa-man' (Appendix, 11. 8-9) at Te Pohue; the 'old man' (1. 116) a real 'cure' (Appendix, 1. 49) at the Tarawera hot spring; the 'Woman and daughter - the man' (1. 123) at the Rangitaiki Hotel, and the 'farm child' (1. 677) and her mother at Runanga. These fleeting descriptions often bear an undercurrent of condescension: Mrs Himing at Runanga, the wife of a manual worker, amused Mansfield because she was 'garrulous' (1.679) and because of her welcome with its pretensions to gentility. Elsie Webber recalled how the mother's welcome of "Come in and sit down. I'll make a cup of tea. I haven't got me drorin' room boots on!” was a pretension that 'tickled K.B. immensely". ${ }^{77}$ But the Himings' child intrigued Mansfield: 'the child's thoughtful fascination' (11. 679-80). Gordon has argued the Himings so intrigued Mansfield that she later transmuted them into the characters of 'The Woman at the Store': the Himings' house became 'a whare roofed in with corrugated iron'; Mrs Himing became the woman whose 'front teeth were knocked out', had 'red pulpy hands, and ... on her feet a pair of dirty 'Bluchers"'; and the child became 'the kid' who drew 'the picture of the woman shooting at a man with a rook rifle' ${ }^{78}$ However much Mansfield may have condescended to, and railed against, the 'third-rate' colonial, backblock settlers continued to intrigue her throughout the camping trip.

It is noteworthy that Mansfield's condescension towards 'the colonial' is frequently manifested in writing directed to her mother. In one letter to Annie Beauchamp she separated herself subtly from her travelling companions by saying: 'I'm quite fond of all the people -

\footnotetext{
76 Buzard, p 59.

77 MS-Papers-4010.

${ }^{78}$ Mansfield, Katherine, The Collected Fiction of Katherine Mansfield, ed. by Gerri Kimber and Vincent O’Sullivan, 2 vols (Edinburgh: Edinburgh University Press, 2012), 1, p. 270.
} 
they are ultra-Colonial but thoroughly kind \& good hearted \& generous - and always more than good to me' (Appendix, 11. 88-90). Two clear assumptions lie behind the statement: firstly, to be 'ultra-Colonial' is to be inferior and, secondly, 'ultra-Colonial' is not a description applicable to either to Mansfield or her mother. Similarly, at Rotorua Mansfield wrote to Annie of her abhorrence for the colonials with whom she took the 'Round Trip' on Lake Rotorua, and with rhetorical confidence expects corroboration from her mother: 'they spoil half my pleasure - don't they yours?' (1. 406). Again, in writing to her mother Mansfield deplores the women tourists in the public baths with the comment 'Women are so apt to become communicate on these occasions that I carefully avoid them' (11. 413-5). Such writing is 'recipient designed" ${ }^{79}$, in the sense that it is intended for a recipient whose views are known and can be taken for granted as common ground. The Urewera Notebook reveals that in 1907 Mansfield's attitude to colonials was contradictory and changeable, and also condescending in ways that were subtly endorsed by her mother.

\section{ii. Mansfield's attitude to Maori}

That Mansfield accords Maori culture importance is evident from the very title page of the Urewera Notebook. Mansfield gave a Maori whakatauki, 'He huruhuru te manu ka rere', pride of place alongside a quotation from her personal and literary hero Oscar Wilde, an Aesthetic adage, and her own nom-de-plume as a writer. Throughout the notebook, there are suggestions that the appearance of Maori captured Mansfield's attention. At Te Pohue she writes, 'saw the sheep sheds - smell \& sound - 12 Maoris - their hoarse crying - dinner cooking in the homestead the roses - the Maori cook - Post letters there - see Maoris' (11. 106-9). At Waiotapu she wrote '[b]ye \& bye we go to see the mud volcano - meet Maoris oh, so different' (11. 350-1). Her translation lists demonstrate an interest in communicating with Maori and an awareness of at least some Maori politico-religious movements of the nineteenth century: 'Hau-Hau paimarere = peace \& goodwill' (11. 741). Mansfield also had some understanding of the twentieth century Maori political movements. At Te Whaiti she described a man simply as 'a follower of Rua' (1.212): clearly she was abreast of the political coverage of Rua in the colonial press.

One strain of the Urewera Notebook was Mansfield's impulse to 'romanticise' Maori culture. At Eskdale in the twilight Mansfield writes of how 'Visions of long dead Maoris - of

\footnotetext{
${ }^{79}$ Alessandro Duranti, Linguistic Anthropology (New York: Cambridge University Press, 1997), p. 299.
} 
forgotten battles and vanished feuds - stirred in me' (11. 66-8). So too, she writes of the mountain Pohaturoa as not only 'an ancient fighting pah' but also 'grim, forbidden silent towering against the sky - an everlasting monument' (11. 450-3). Her descriptions of Maori houses and pa-sites are at times imbued with a mystique almost supernatural: 'we pass several little whares - deserted and grey - they look very old and desolate - almost haunted' (1. 245-8). All such descriptions reveal something about what Mansfield wanted and expected of Maori. Stafford and Williams have shown there is evidence in the notebook that Mansfield shared the common presumption that Maori, as 'noble savage', belonged to a dying 'conquered race' ${ }^{80} \mathrm{~A}$ sense of pathos for their inevitable decline is seen in a vignette where Mansfield describes her Maori protagonist as 'passionate' and 'violent' but also 'tragic' (11. 635-6).

There is also some evidence in the notebook to suggest that when Mansfield's expectations of Maori were not met, her interest turned to disappointment. The Urewera Notebook demonstrates what John Frow has called the 'structural role of disappointment' inevitable in travel writing when expectations and preconceptions of an 'ideal type' are not met. ${ }^{81}$ After vising Te Umuroa in the Urewera, Mansfield registered her dissatisfaction at finding the next settlement they visited distastefully westernised:

this place proved utterly disappointing after Umuroa, which was fascinating in the extreme - the Maoris here know - some English and some Maori - not like the other natives - Also these people dress in almost English clothes compared with the natives here - and they wear a great deal of ornament in Umuroa \& strange hair fashions - I found nothing of interest here (11. 280-6).

In such opinions Mansfield was like the "hundreds of Europeans who desire[d] nativism and 'authenticity"' when observing Maori. This was evident from the earliest guide book writers like Thorpe Talbot, who in The New Guide to the Lakes and Hot Springs (1882) wished that Maori would not 'affect European attire ... for the few that I have seen bareheaded, barelegged, and enveloped in the korowai looked so much more imposing', 82

\footnotetext{
${ }^{80}$ Stafford and Williams, p. 159.

${ }^{81}$ John Frow, Time and Commodity Culture: Essays in Cultural Theory and Postmodernity

(Oxford: Clarendon Press, 1997), p 67. For evidence of the influence of Frow's ideas see Wevers, p. 172.

${ }^{82}$ Wevers, p. 199.
} 
However, it is notable that Mansfield disliked Maori performing themselves as 'authentic' in order to benefit from the tourist economy. Rotorua prided itself on being home to 'a mixture of Maori and European civilisation' ${ }^{83}$ and by performing dances for sightseers and making model villages, Rotorua Maori attempted to salvage some financial gain. But for Mansfield, the 'little naked boys and girls' (1. 368-9) at Whakarewarewa who dived for money in the thermal waters, were a tourist ploy. Cooed over by many other tourists, these children elicited from Mansfield only displeasure; she recorded their 'coy airs bah!' (1. 369). Mansfield's sense of finding no 'authentic' Maori in Rotorua is emphasised when, leaving the town, she writes in her notebook: 'meet a Maori again - walking along - barefooted and strong' (11. 380-1). The man puts on no false display, or as Mansfield puts it, showed no 'maudlin affectation' (1. 382). Thrilled to find a 'real' Maori, she describes her heart as finally 'warm again' (1. 390), and is prompted to interact with him: 'she shouted Te nakoto' (1. 381-2). ${ }^{84}$

What has not been noted before but is evident from the notebook is the fact that Mansfield gained intimate access to, and respectfully engaged with, people who could not have met her expectations of the 'pure' Maori, either in habit, custom or appearance. Murupara, which Mansfield describes as 'the 'city' ... a store - an Accomodation House - and a G.P.O.' (11. 166-7) was in 1907 essentially a collection of buildings in the ownership of Irishman immigrant William Henry Bird and his Ngati Manawa wife, Kiekie. William Bird's previous wife had also been Maori, and he is remembered by his descendants as being actively engaged in Maori society and working as an interpreter on behalf of the local Ngati Manawa population. At the same time, his accommodation house was a fishing lodge tailored specifically to European guests (such as ‘Mrs Prodgers ... and other Englishmen' (11. 167-8) whom Mansfield met there). ${ }^{85}$ Upon encountering the mixture of European and Maori culture at Murupara, Mansfield registered not disappointment but fascination for the fusion of cultures: 'the Maori women are rather special - the Post-boy - the children - an accident to the horses - very great - the Maori room - the cushions.' (11. 168-70).

\footnotetext{
${ }^{83}$ The Cyclopedia of New Zealand: Industrial, Descriptive, Historical, Biographical Facts, Figures, Illustrations, 6 vols (Wellington: Cyclopedia Co., 1902), 2, p. 799.

${ }^{84}$ This scene could not be understood in these terms previously due to the misreadings of previous editors, and to the fact that no prior edition marshalled the physically separated pieces of writing that collectively form this single entry. Ironically, Mansfield used the wrong greeting, see 1. 381n.

${ }^{85}$ Personal communication with Pem Bird, Henry and Queenie Nuku, Rita Teddy and Bert Messent of Ngati Manawa.
} 
Even within the Urewera, Mansfield demonstrated an interest in and respect for people who were, to use the nineteenth century term, 'half-caste'. This is most evident in her descriptions of the Warbrick family: Albert Warbrick was of European and Ngati Rangitihi descent, his wife was of European and Ngati Porou descent, and their niece, Joanna Kaua, was born to parents who were part European and part Maori. ${ }^{86}$ Albert Warbrick's family, particularly his brother Alfred, were active participants in Pakeha society, ${ }^{87}$ and Mansfield's description of the Warbrick family home, displays what Pratt terms transculturation ${ }^{88}$, in this case as the Warbricks adopt elements of both Maori and Western culture: 'the clean place - the pictures - the beds - Byron \& the candle - the flowers in a glass - sweet - the paper \& pens - photos of Maoris \& whites - too - Johanna stays by the door we see her jewellery, her Mothers' (11. 316-9). In spite of this, Mansfield's interest in and empathy for Joanna results in some of the most insightful and sophisticated writing in the notebook. Mansfield appears to realise that Joanna, who is 'so lovely' (1.323) and 'reads Byron \& Shakespeare \& wants to go back to school' (11. 322), is trapped by her historical circumstances: her life consists of an unending cycle of chores about the house, milking the cow and 'watering her garden' (11. 309-10). Mansfield responds to Joanna with insight into the shy orphan who straddles two cultures, and whose intelligence and aspirations to European 'high culture' surpass her socio-economic means: 'there is something sad about it' (1. 322), Mansfield concludes.

It is important to acknowledge that such empathy and respect pose a stark contrast to the attitudes of many of Mansfield's contemporaries. The ethnographer Elsdon Best, acting as Government Sanitary Inspector in 1906, echoed numerous government officials when he described Te Whaiti as one of 'the most deplorable and backward places' where Maori are lethargic: 'they seem more and more inclined to appeal to the government for grants of food ... The European must take the matter in hand and insist upon a change being made. ${ }^{89}$ Mansfield, in the same place and the same time as Best, registered poverty ('the Mother \& the poor baby - white \& naked' (1. 209)), yet her instinct was to praise the innate nobility of the inhabitants and to note down the elements of refinement with which they had sought to grace their homes. For Mansfield, the impoverished mother of many offspring has 'a splendid face \& regal bearing' (1. 210), Warbrick had a 'regal figure' (1. 216) and the houses were

\footnotetext{
${ }^{86}$ Personal communication with Dr Paerau Warbrick.

${ }^{87}$ See $1.195 n$.

${ }^{88}$ Pratt, p. 7-8.

${ }^{89}$ Appendices to the Journals of the House of Representatives, 1906, I H-31, pp. 1-94 (p. 76 ).
} 
'charming' with their 'roses $\&$ pinks in the garden ... the kettle \& fire $-\&$ bright tins ... photos - a chiming clock - mats - kits - red table cloth - horse hair sofa' (11. 202-8).

Even within the camping party, Mansfield's facility for empathy and respect was unusual. When trudging over the Kaingaroa Plains and searching for water, Mansfield's camping party happened suddenly upon two Maori men. Mansfield noted their poverty, and her fascination for these 'dark people' and their language, which she tries to capture:

By and by through the track we met two men Maoris in dirty blue ducks - one can hardly speak English - They are surveyors - We stop - boil the billy \& have tea \& herrings Oh! how good - Ahead the purple mountains - the thin wretched dogs - we talk to them - $\underline{\text { thin. }}$ We drive the horses off but there is no water - the dark people the conversation - E ta - Haeremai te kai - it is cold (1l. 146-152).

Mansfield's approach and language are in direct contrast to Millie Parker's description of the same events:

At that very moment two Maoris on horseback suddenly appeared over a ridge ahead of us, and you can imagine with what excitement we hailed them. Our first question was "Where is water?" And the answer came, "Water? Aw, prenty all de way." It seems that we had quite often been near the river had we known just where to step aside from the track to find it. ${ }^{90}$

Significantly, Mansfield quotes the men's Maori; Millie mocks their English.

\section{iii. Mansfield's attitude to the landscape}

During her camping holiday Mansfield described New Zealand's landscape at much greater length than she described its people; the camping notes consist chiefly of long depictions of passing scenery. But for all the attention that Mansfield paid to the landscape, much of her description is conventional and sometimes even disengaged. As she travelled through the North Island, Mansfield was frequently confronted by the after-effects of the large-scale burn-off of native forest: leaving Murupara she described the 'great stretch of burnt manuka'

\footnotetext{
${ }^{90}$ M.A.P., 'No Water', New Zealand Herald, 21 March 1931, p. 4.
} 
(1. 337) and at the Waikato she noted 'a clearing of burnt manuka' (1. 474) and 'all the stretch of burnt manuka ... around them' (11. 482-3). Yet Mansfield seemed less concerned than some of her contemporaries that the bush was vanishing. On the train out of Wellington, she encountered the evidence of burnings first-hand:

Everywhere on the hills - great masses of charred logs - looking for all the world like strange fantastic beasts a yawning crocodile, a headless horse - a gigantic gosling - a watchdog - to be smiled at and scorned in the daylight - but a veritable nightmare in the darkness and now $\&$ again the silver tree trunks - like a skeleton army, invade the hills (11. 28-33).

Mansfield registered the ugliness of the landscape, but her imagery was concerned with the power of the human imagination rather than the loss of the vanishing bush. Yet some contemporaries were becoming aware of the irretrievable loss of New Zealand's native bush, and colonials' impact on the countryside. Blanche Baughan's 1908 poem 'Burnt Bush', for instance, uses the image of a skeletal army to critique the irreparable destruction rather than dismiss it:

Gaunt tree-skeletons,

Tall blacken'd splinters,

Limbless, and leafless, and lifeless for ever,

In piteous distinctness

Starkly appear ${ }^{91}$

Wevers has pointed out that most tourists to New Zealand at the end of the nineteenth century developed 'standard descriptive modes through constant reiteration and aestheticisation', ${ }^{92}$ and by relentlessly comparing features of the New Zealand landscape with similar scenery in other parts of the Western world, locked into place 'a set of associations that help[ed] to define New Zealand as a country pleasing to European taste'. ${ }^{93}$ Much of Mansfield's writing about landscape demonstrated this same insistent comparison with the landscape of Europe.

\footnotetext{
${ }^{91}$ Blanche Baughan, Single-short and other verses (Christchurch: Witcombe and Tombs, 1908), p. 20.

92 Wevers, p. 190.

${ }^{93}$ Wevers, p. 6.
} 
In the notebook her descriptions are frequently through reference to iconic European models of literature, music and art. Standing in the Urewera heartland early one morning, she compared the dew on the bracken to the 'dream flowers' (1. 266) described in H.G. Wells' The Time Machine (1898); the Hamurana Spring resembled a painting by John Everett Millais with its 'tangle of willow \& rose \& thorn (11. 445-6); the 'fern grotto' (1. 583) behind the Huka Falls reminded her of the setting for the Opera Tannhauser; a 'great black rock' (1. 486) on the banks of the Waikato was reminiscent of another Wagnerian opera, Der Ring des Nibelungen. In these passages Mansfield's descriptions of landscapes owe something to the 'romantic gaze' as defined by Urry: rendering description as a rather 'elitist - and solitary appreciation' of natural magnificence, and in utilising her own considerable cultural capital to do so, with particular reference to European 'high culture'.94

More commonly Mansfield fell back on simple descriptions of the country anglicised. Instead of native plants and indigenous wildlife, Mansfield alluded to 'larks in the sun' (1. 127), 'a creek ... the sides all smothered in daisies' (Appendix, 1. 16), 'clematis \& orchids' (1. 118), 'blue forget-me-nots' (1. 522) and a 'golden poppy' (1.493). Very often the New Zealand of the Urewera Notebook that Mansfield most delights in is one thoroughly Europeanised. Mansfield described herself as 'blissfully happy' (11. 658) at Taupo, but it ought to be noted that the campsite at Lake Taupo was not in New Zealand bush, but in the miniature England of the Terraces Hotel grounds. Here, mounting in the coach 'through great avenues of pines $\&$ acacias - to the Terraces Hotel' (11. 646-7), she found 'lawns and cut trees - little corners long hidden walks - shady paths' (11. 647-8). Her 'bliss' arose not from the native New Zealand bush, but finding a corner of New Zealand where 'honeysuckle - roses pink \& white - periwinkles syringas - red hot pokers ... Fruit trees with promise of harvest' (1. 660-2) grew as prolifically as in the Northern Hemisphere.

But as with her attitudes to colonials and Maori, in her descriptions of the landscape Mansfield was at times unconventional. A contrast can once again be made with Mansfield's fellow campers. In particular, Mansfield generally described the Urewera bush without the hackneyed connotations of her friend, Millie Parker, who described the party's ascent into the Urewera mountains through highly romanticised imagery:

\footnotetext{
${ }^{94}$ Urry and Larsen, p. 100.
} 
the winding road leads you on into the land of ancient witchery.

Ghostly and grim above you stretch the lichen-covered arms of hoary

forest giants as you pass through the silent shade. Verdigris of the

ages clings to their knotted limbs like clots of sailed sea foam. ${ }^{95}$

Mansfield's description of the same bush displays her difference. She strived for concrete description to evoke strangeness and splendour, writing of 'the birds calling through the night' (1. 223), the 'mile upon mile of green bush then brown russet colour' (1. 231-2), 'the green hill in vivid sunlight $\&$ then a vault of green bush the sunlight slanting in to the tree an island in the river decked with tree fern' (11.242-4) and 'the trees smothered in cream blossom' (1. 253-4). There is evidence of this in her hasty 'reportage' descriptions of the scenery throughout the rest of the country: the 'scrub covered valleys' (1. 141), 'fluff in the manuka - snow berries', (11. 127-8) 'bush ravines' (11. 102), feathery plumed 'toi-toi' (1. 518), 'the dew on the grass \& manuka' (1. 684-5), 'the bush birds' cries' (1. 186) and 'a valley of broom' (1. 671) crisply evoke New Zealand. In this evocative description of the landscape, Mansfield was practising a technique that she carried forward from 'The Woman at the Store', and so prefigured the writing that marked her mature oeuvre. ${ }^{96}$

\section{Conclusion}

Angela Smith has described Mansfield's early personal writing as permeated by 'the impression of living in-between, with home being neither here nor there' ${ }^{97}$ This sense that she had a firm foot in neither colonial New Zealand nor the metropolitan London, may be the reason that has enabled successive editors and biographers to call upon the Urewera Notebook as evidence both for and against her unhappiness in New Zealand. This edition, with a detailed consideration of the context in which the notebook was written, shows that in 1907 Mansfield in fact discovered different worlds within New Zealand. As the camping party traversed a relatively small part of the North Island, they encountered a number of radically different societies, economies, histories and landscapes. Mansfield's responses in the notebook entries show her to have been more sensitive to these than were her

\footnotetext{
${ }^{95}$ Margaret A. Parker, 'A Summer Day in 1907', New Zealand Herald, 4 April 1931, p. 6.

${ }^{96}$ For a comparison of the language of the Urewera Notebook with 'The Woman at the Store', see Mansfield, The Urewera Notebook, ed. by Ian A. Gordon, pp.27-8.

${ }^{97}$ Katherine Mansfield, Selected Stories, ed. by Angela Smith (Oxford; New York: Oxford University Press, 2002), p. ix.
} 
companions. She was still a complex mixture of conventional and insightful thinking: disdainful of the 'ultra-Colonial' but intrigued by backblocks settlers; disappointed when Maori were not the noble native of stereotype but empathetic when she encountered the real predicament of Europeanised Maori; blissfully happy in English gardens at Taupo, yet everywhere ready to capture the strangeness of New Zealand. So if in general Mansfield's early personal writings were infused with a sense of 'living in-between, with home being neither here nor there', the Urewera Notebook shows her steadily developing a literary facility for capturing the here and now. 


\section{$\underline{\text { Textual Introduction }}$}

\section{The Urewera Notebook: Physical description}

At 180 millimetres high, 110 millimetres wide and 15 millimetres thick, Mansfield's original notebook is small, slender and unremarkable in appearance. It is bound in black leather cloth, has lined, ivory coloured pages and endpapers patterned with a lattice of red fleurs-de-lis. Now considerably dilapidated, its front cover is cracked, its spine is partially disintegrated and the decorative endpapers have faded to muted tones. Numerous torn stubs along the binding indicate where pages were detached before the notebook's acquisition by the Alexander Turnbull Library, and many of the remaining pages literally hang by a thread. The notebook contains 170 folios in total: during the camping holiday Mansfield filled the first half of these, as well as seven folios at the very end of the notebook. ${ }^{98}$ She continued to fill the remaining pages in England in 1908 and concluded her entries in Belgium in April 1909. The notes made during the camping holiday, although physically dispersed, constitute a 'detached and self-contained episode'. 99

The notebook's inconspicuous appearance belies the complexity of its contents. Mansfield's notes are anything but a conventional diary: rather than chronicling quotidian events she used her notebook as a compendium for unrevised, fragmentary prose, interspersed with translations, uncompleted letters, expenditure and laundry lists, and occasional drawings. Very occasionally she made revisions of earlier entries but, on the whole, the notes consist of draft depictions of incidents and sensations, and descriptions of locations which are not always identifiable to the uninformed reader. Mansfield's manner of filling the notebook was similarly eccentric: she seldom indicated the beginning of new entries, seamlessly abutted entries written on separate occasions and jumped back and forth between pages to fill empty spaces. Her fluid use of the past and present tense within single entries ('Monday night we slept outside Warbrick's whare ... in the distance I see the niece Johanna' (11. 305-9)) makes

\footnotetext{
${ }^{98}$ Specifically, 85 folios bear inscriptions relating to the 1907 camping holiday. Upon its acquisition by the Turnbull, the manuscript's pages were numbered in the upper right hand corner. Archivists used a foliated numbering system, and did not include the pages between folios 77v and 79, as Mansfield had left these entirely blank. When digitising the notebook, the Turnbull preserved this same foliation. For consistency, my foliation concurs with that of the Turnbull, however in total the notebook contains two folios more than this numbering system would seem to suggest.

${ }_{99}$ Mansfield, The Urewera Notebook, ed. by Ian A. Gordon, p. 19.
} 
it difficult to know whether much of the notebook was written in hindsight, or contemporaneously with the events described. Mansfield's heavy reliance on a dash as her principal form of punctuation, and her faintly pencilled and exceptionally untidy handwriting, render large sections of the notebook agonisingly difficult to decipher. It is scarcely surprising that the Urewera Notebook is regarded by Mansfield scholars as posing 'extreme difficulties'. 100

\section{Editorial history}

Three editors have already grappled in diverse ways with the task of rendering comprehensible an innately disorientating manuscript. Three dissimilar editions of the notebook have been produced as a result: driven by different emotional commitments, each editor has presented the text in a different sequence, offered different spelling and punctuation and supplied a different level of annotation. These various editorial strategies have carried profound implications, enabling editors to construct subtly different portraits of Mansfield over time. The Urewera Notebook has been reproduced selectively, editorially 'polished' and couched within factually inaccurate or inappropriate annotation by Murry to cast its author as an exotic, eloquent diarist. Gordon adhered much more closely to Mansfield's text, producing almost all of the original material, together with a wellresearched historical commentary. Yet by rearranging and annotating the text to create a linear narrative, and intermingling his commentary with subjective interpretation, Gordon transformed Mansfield into a short story writer whose birthplace was a stimulating physical and intellectual foothold. Scott has offered a technically accurate transcription, but by presenting the text in the order in which entries occur in the manuscript without the support of a scholarly apparatus, she left her readers to pick their way through a bewildering text whose author is at times unintelligible. The following summary of the editorial history of the Urewera Notebook proves a significant point: our perceptions of Mansfield owe much to her writing, but almost as much to the preoccupations of her editors.

\footnotetext{
${ }^{100}$ C.K. Stead, 'Meetings with 'the Great Ghost', in Celebrating Katherine Mansfield: A Centenary Volume of Essays, ed. by Gerri Kimber and Janet Wilson (Basingstoke: Palgrave Macmillan, 2011), pp. 214-28 (p. 219).
} 


\section{John Middleton Murry: The Life of Katherine Mansfield (1933) and the Journal of Katherine Mansfield 1904-1922: Definitive Edition (1954)}

\section{i. John Middleton Murry: Context}

Following Mansfield's death in 1923, Murry gained complete authority over her literary estate. He acquired legal jurisdiction over her published work for the following 50 years, while her unpublished work - including the Urewera Notebook - became his absolute property 'in perpetuity'. ${ }^{101}$ Murry immediately set about publishing Mansfield's work at a prolific rate. While editor of The Adelphi, he included a contribution by Mansfield in every issue of the magazine between June 1923 and July 1924, and over the following three decades collaborated on one biography and edited no fewer than 12 separate editions of her poems, letters, prose, and literary criticism. ${ }^{102}$ While Murry was editing his late wife's material, he was also producing a body of criticism, poetry and novels about Mansfield and her literary achievements, insistently emphasising her ethereal fragility, her 'genius', ${ }^{103}$ her 'purity of soul', ${ }^{104}$ and 'exquisite individuality', ${ }^{105}$ at the expense of other characteristics. Murry's treatment of Mansfield's literary estate drew immediate criticism from contemporaries, who saw his glorification of Mansfield, and his saturation of the market with her material, as an exercise in hagiography that distorted her literary qualities while bolstering his own wealth and reputation. Lytton Strachey famously proclaimed, 'why that foul-mouthed, virulent, brazen-faced broomstick of a creature should have got herself up as a pad of rose-scented cotton wool is beyond me', ${ }^{106}$ while D.H. Lawrence made the snide, but significant, observation of Murry's editing: 'I hear he inserts the most poignant passages himself'. ${ }^{107}$

\footnotetext{
101 Jones, p. 39.

102 Harry Ricketts, 'John Middleton Murry: Keeper of the Flame' in Katherine Mansfield's Men ed. by Charles Ferrall and Jane Stafford (Wellington: Katherine Mansfield Birthplace Society and Steele Roberts, 2004), pp. 106-23 (p. 117).

${ }^{103}$ Mantz and Murry, p. 2.

${ }^{104}$ John Middleton Murry, 'The Weariness of Ivan Bunin', Dial, 76 (1924), 194-7 (p. 195).

105 Katherine Mansfield, The Dove's Nest, and Other Stories, ed. by John Middleton Murry (London: Constable, 1923), p. 10.

106 Michael Holroyd, Lytton Strachey: The New Biography (New York: Norton, 1994), p. 573.

${ }^{107}$ D.H. Lawrence, The Cambridge Edition of the Letters of D.H. Lawrence, ed. Keith Sagar and James T.

Boulton, 7 vols (Cambridge: Cambridge University Press, 1979), VII, p 55.
} 
All this is well-rehearsed, and indeed rather notorious within Mansfield scholarship, but worth repeating as it forms the background to Murry's treatment of the Urewera Notebook. Murry made use of the Urewera Notebook twice in his dissemination campaign. He quarried Mansfield's notebooks for The Journal of Katherine Mansfield (1927), but not until 1933, when he co-authored The Life of Katherine Mansfield, did he bring the Urewera Notebook to light. A young American scholar, Ruth Mantz, wrote much of this biography, which devoted a chapter to discussion of Mansfield's 1907 camping holiday, but Murry presided over the notebook material (Mantz' tasks were confined to 'collating and assessing the facts then available' but simply observing Murry's method of 'selecting, arranging and editing' his transcriptions). ${ }^{108}$ Murry made further use of some notebooks in The Scrapbook of Katherine Mansfield (1937) but did not again use the Urewera Notebook until 1954, when he published it for a second time in the Journal of Katherine Mansfield 1904-1922: Definitive Edition. Murry explained that the Definitive Journal 'restored' passages 'which for various reasons were suppressed' in the 1927 Journal and included 'innumerable minor corrections' as a result of 'more careful study of manuscripts'. 109

\section{ii. John Middleton Murry: Editorial methods}

A comparison of Life and the Definitive Journal with the original notebooks explains and justifies Murry's sullied reputation as an editor: his editorial intrusion into the Urewera Notebook was immense. Murry undoubtedly assumed a formidable task in transcribing the manuscript, which was written by a teenage Mansfield with whom he was unfamiliar, and described a country and society of which he was ignorant. Some of his misreadings were almost certainly ingenuous, as for example his frequent misspelling of Maori words (which Mansfield herself had sometimes misspelt): where Mansfield wrote 'E ta - Haeremai te kai' (1. 151), Murry read 'Eta hoeremai te kai' in Life (p. 292) but corrected his reading to 'E ta, haeremai te kai' in the Definitive Journal (p. 25). Despite this, it is also tempting to conclude that if Murry had difficulties with Mansfield's handwriting, he also made astoundingly little effort to be accurate. Mansfield described leaving Taupo and passing through 'Opipi' (1. 667) before reaching Rangitaiki: Opipi, more often spelt Opepe, was a well-known historical site

\footnotetext{
108 Ruth Elvish Mantz, 'Katherine Mansfield: Tormentor and Tormented', in The Critical Response to Katherine Mansfield, ed. by Jan Pilditch (Westport, CT: Greenwood Press, 1996), pp. 127-9 (p. 129).

${ }^{109}$ Katherine Mansfield, Journal of Katherine Mansfield 1904-1922: Definitive Edition, ed. by John Middleton Murry (London: Hutchinson, 1954), p. ix.
} 
identified in numerous guide-books and maps of the period. ${ }^{110}$ Yet in Life Murry transcribed Mansfield's 'Opipi' as 'Waihi' (p. 306). ${ }^{111}$ Since Waihi is a town on the Coromandel Peninsula some considerable distance from Taupo, and clearly no stopping-point on the route to Rangitaiki, the reader is led to doubt whether Murry ever consulted a map, and indeed to suspect that such mistakes are evidence of the 'general and extreme carelessness' that previous scholars have detected in his editorial work. ${ }^{112}$

Regardless of whether such individual misreadings were innocent or inept, it is clear that ingenuous errors were far outweighed in Murry's transcriptions by evidence of deliberate editorial tweaking. Significantly, Murry's two transcriptions of the notebook provide different coverage. Of the 85 folios that Mansfield filled during the camping trip, Life reproduced 34 in entirety, 31 incompletely, and omitted 18 altogether. The selections reproduced were drawn intermittently from across the whole span of the notebook and include various kinds of text - descriptions, fictional vignettes, translations and draft letters but the text that was omitted contained some of the notebook's most prescient and sophisticated writing. For instance, Life omitted Mansfield's description of 'the niece Johanna', a sketch in which Mansfield's psychological insight into a young girl's 'liminal state' prefigures so much of her mature fiction. ${ }^{113}$ The exclusion of such a key passage from Life limited readers' appreciation of Mansfield's progress as an author 'in training'.

Two decades later, in the Definitive Journal, Murry reproduced an even smaller section of the notebook: 30 folios were transcribed in full, 14 transcribed partially and 39 omitted. As justification for this partial coverage, Murry claimed in a headnote 'a great deal of Katherine's pencil diary' was 'illegible' (p. 22). This was a curiously feeble excuse: as Murry had transcribed much of the notebook for Life in 1933, it would have been plain to anyone who compared the works that he truncated his transcription deliberately in 1954. The Definitive Journal omitted all draft letters, marginal notes and translations, giving the impression that Mansfield's notebook was a conventional diary rather than a compendium for translations, lists and notes of diverse kinds. Moreover, in the Definitive Journal Murry provided patchy coverage of folio 2 through to folio 24 of the original manuscript, and more

\footnotetext{
${ }^{110}$ See, for instance, the route-map in this edition. See also $1.667 \mathrm{n}$.

${ }^{111}$ Murry omitted this word from the Definitive Journal.

112 Philip Waldron, 'Katherine Mansfield's Journal', Twentieth Century Literature, 20 (1974), 11-18 (p. 12).

113 Angela Smith, Katherine Mansfield and Virginia Woolf: A Public of Two (New York: Clarendon Press, 1999), p. 119.
} 
or less omitted the second half of the camping notes. This meant he excluded Mansfield's self-titled 'Vignette' (1. 604), a creative sketch in which Mansfield demonstrated her early habit of reworking into fictional form, people and episodes from real life. Bella, whom she had met at Troutbeck Station and described as 'the very dusk incarnate' (1. 188-9), reappears in the vignette as the 'young Maori girl' (1.626) portrayed as 'the ${ }^{\wedge}$ very $^{\wedge}$ incarnation of evening' (1. 643). As in Life, the omissions from the Definitive Journal constrain the reader to a view of Mansfield as a conventional diary-writer, when in fact she was a practising literary experimenter and a habitual interweaver of fact and fiction.

In both of his transcriptions Murry made surreptitious use of elision, omitting words, phrases or even paragraphs, to present text as seamless, uninterrupted passages. In some instances he provided an ellipsis to indicate an omission, but the reader was inevitably prevented from judging the nature and importance of the excluded text. To take a key example, in Life Murry transcribed Mansfield's entry for Saturday 7 December as:

\section{"SATURDAY. \\ "Letters ... The quiet afternoon- (p. 298).}

In the Definitive Journal he made similar use of elision: 'Saturday Letters ... The quiet afternoon-' (p. 31). A complete transcription of the entry reads: 'Saturday letters - far more - \& lunch with Tom, \& the quiet afternoon' (1.370). Omitting the reference to 'lunch with Tom' may have seemed inconsequential to Murry, but for anyone seeking to understand Mansfield's social milieu in New Zealand its exclusion is significant: Tom was T. E. Y. Seddon, son of the late Premier Richard Seddon, and his appearance in Mansfield's notebook offers a clue to her privileged social colonial networks. ${ }^{114}$ There is also evidence that Murry was strategic, rather than simply careless, in his use of ellipses. In Life he transcribed Mansfield's description of the mountain Pohaturoa as follows: 'at the top of this pah a spring bubbled ... Then rounding the corner, they saw the Wairakei [sic] River' (p. 298). In the Definitive Journal he offered an expanded reading: 'at the top of this peak a spring bubbled. In the blue evening it was grim, forbidding, silent, towering against the sky - an everlasting monument. Then rounding the corner, they saw the Waikato river' (p. 31). That Murry subtly altered his ellipses when reworking his transcriptions from Life for inclusion in the Definitive

${ }^{114}$ See 1. 370n. 
Journal, suggests he applied them not only because the text was illegible, but for the more strategic purpose of crafting Mansfield's text.

Both of Murry's transcriptions were stylistically 'airbrushed': spelling and punctuation were 'corrected', so that where Mansfield wrote 'a cheque rug' (11. 80-1), Murry transcribed 'a check rug' in both Life (p. 288) and the Definitive Journal (p. 24). Where Mansfield wrote 'Accomodation' (1. 167) Murry transcribed 'Accommodation' (Life p. 292; Definitive Journal p. 27). Mansfield relied on the dash as almost her sole form of punctuation but Murry 'interpreted' these dashes as colons, semi-colons and commas, to neatly divide and tidy sentence structure. So where Mansfield wrote 'In the distance these hills to the right, almost violet, to the left grey with rain' (11. 336-7), Murry polished the text through the imposition of standard punctuation: Life reads 'In the distance these hills; to the right, almost violet; to the left, grey with rain' (p. 297) and, similarly, the Definitive Journal reads 'In the distance the hills; to the right, almost violent; to the left grey with rain' (p. 30). As with ellipses, Murry modified his insertion of punctuation between editing Life and the Definitive Journal. Where Life read: 'A grey day and I drive long dusty thick road and then before us Tarawera, with the great white clefts_-' (p. 294), the Definitive Journal read: 'A grey day and I drive. Long dust-thick road; and then before us, Tarawera, with the great white cleft—' (p. 29). Examples such as this suggest that Murry was very deliberately transforming draft notes into a technically elegant work of literature.

Finally, Murry placed the Urewera Notebook within the recognised 'genre' of diary writing. He decided where one 'diary entry' ended and another began, italicised words signalling the beginning of new entries (e.g. 'Tuesday morning') and indented all internal paragraphs. Mansfield filled the first four lines of folio 2 with text immediately abutting the right hand margin; 'Urewera - Kaingaroa Plains' (1. 12n) is scrawled in large, bold lettering across the header. By slotting in a date that Mansfield had written on folio $1 \mathrm{v}$ and capitalising, rearranging and indenting the text, Murry gave to this scruffy entry the appearance of a deliberately styled diary in Life:

\section{KAINGAROA (URIWERA) PLAIN.}

"November, 1907.

"On the journey, the sea was most beautiful, a silver point etching and a pale sun breaking through pearl clouds. 
"There is something inexpressibly charming to me in railway travelling. (pp. 285-6)

The Definitive Journal shows evidence of further reformatting, perhaps with the objective of presenting a yet more elegant diary opening:

Kaingaroa Plain. On the journey the sea was most beautiful, a silver-point etching, and pale sun breaking through pearl clouds.

There is something inexpressibly charming to me in railway travelling. (p. 22)

The consequence of Murry's cosmetic editing, his selection and rearrangement of the text, was to repackage the Urewera Notebook into a technically elegant example of a popularly recognised 'diary' genre.

This catalogue of Murry's editorial intrusions into the Urewera Notebook should not mask the fact that editorial intrusion may have seemed to him, not devious or deceptive, but entirely appropriate. A letter left by Mansfield's nephew, Andrew Bell, offers further corroboration for this point. Bell, writing in 1975, recalled: 'My family took a most dim view of Middleton Murry' but '[b]eing of a different generation, I ventured to look him up in England'. Having challenged Murry about his decision to publish Mansfield's work which was not 'worthy to be published', Bell was mollified when Murry 'claimed that he had had to do a great deal of editing because he alleged the spelling of my Aunt was very poor and the punctuation was hopeless'. Indeed, upon learning that Murry had polished Mansfield's text for these reasons, Bell's attitude 'softened' and he concluded that Murry was actually 'extremely kind'. ${ }^{115}$ Murry's candid avowal of his editorial intervention suggests that he did not see himself in the business of providing a diplomatic transcription, and possibly felt his role as editor entailed a degree of textual 'sculpting' which the public should appreciate. Nevertheless, for anyone wishing to obtain an accurate sense of the original manuscript, Murry's transcriptions of the Urewera Notebook were patently inadequate.

${ }^{115}$ Wellington, Alexander Turnbull Library, MS-Papers-6984-27, Andrew B. M. Bell to Ian A. Gordon, 18 November 1975 . 


\section{iii. John Middleton Murry: Contextual aids}

The problems caused by Murry's editorial intrusions were compounded by the kind of commentary he supplied. In Life, Murry and Mantz couched notebook transcriptions within an authorial commentary that relentlessly emphasised Mansfield's aesthetic sensibilities and spiritual connection to the 'wild and beautiful primitive country' (p. 307) and to 'Maoris in their native pahs' (p. 289) at the expense of factual accuracy. The commentary described a wildly inaccurate itinerary, and presented extracts from the notebook to coincide with this unfeasible timetable. One egregious error was their introductory assertion that 'the caravan started through the Petane Valley, east, through the King Country- the Kaingaroa Plain - to Rotorua' (p. 285). The Kaingaroa Plains and the King Country are not one and the same location as this extract seems to suggest, and the camping party certainly never entered the King Country in the eastern North Island. Extracts from the notebook were also embedded in observations about Mansfield's sensitivity, with comments like 'she was a barometer to elusive and usually unperceived differences' (p. 296) and 'All of the outer layers, hardend by conflict, by friction, were peeled away, leaving the mind so sensitive to beauty reflecting from innumerable facts any loveliness to which it might be exposed' (p. 305). The authors also stressed the 'uncultivated' (p. 284) and wild 'beauty and colour and strange magic' (p. 303) of the New Zealand 'wilderness' (p. 290). In short, the commentary in Life stressed Mansfield's ethereal sensitivity, and almost mystical connection to a wild, otherworldly country, at the expense of factual accuracy.

In the Definitive Journal Murry adopted the opposite strategy to achieve a similar outcome. Instead of an extensive commentary, he supplied only one brief paragraph to introduce the text, in which he stated the dates of the journey's commencement and conclusion, and conjectured on Harold Beauchamp's reasons for sanctioning the trip:

Whether to fill up time before her proposed departure, or to be freed from her embarrassing presence ... or - it is conceivable - to make her acquainted with an aspect of New Zealand she ignored in her passionate repudiation of its urban civilisation (p. 22).

Except for two concise footnotes, the reader was offered no further explanation of the location or nature of events described. Undoubtedly Murry could have elucidated the text with a fair degree of accuracy had he seen fit: Wevers points out that by the time of 
Mansfield's 1907 camping trip, an 'ever-increasing flood' of travel literature and guidebooks describing the region had been pouring out of British (and New Zealand) publishing houses. ${ }^{116}$ More such material continued to emerge between 1907 and 1954. Murry's decision not to annotate the Definitive Journal with any of this information prevented the reader from acquiring an even basic understanding of the route and the participants of the trip. In the absence of any annotation, Mansfield was revealed to the reader through a mysterious sequence of encounters in a strange and amorphous landscape. Whether intentional or inadvertent, Murry used the Urewera Notebook in different ways to portray Mansfield as an articulate diarist developing a spiritual connection to her exotic homeland.

\section{iv. John Middleton Murry: Critical reception}

On the whole, the appearance of the Urewera Notebook in Life was given minimal critical attention. ${ }^{117}$ Reviewers found fault with the biography as a whole on numerous counts, such as its emphasis on Mansfield's early life at the cost of her adult years, and its premature timing. Yet all reviewers accepted the image of Mansfield as a rare and sensitive genius in New Zealand. Thus, The Times criticised Life as 'half the story, and the less important half', ${ }^{118}$ and the Auckland Star noted that Mansfield was 'too new and raw a topic ... this book has come too soon'. ${ }^{119}$ Yet the Sydney Morning Herald described Life as the biography of a 'rare spirit' who found 'crude colonial life uncongenial', ${ }^{120}$ and a review in the Times Literary Supplement held that 'if England was to teach her how to write, New Zealand Wellington, the Sounds, Karori - had given her what she was to write about ... [h]er sufferings were evidently those of a sensitive spirit in an uncongenial rather than an antagonistic environment'. ${ }^{121}$ One New Zealand reviewer even criticised Murry for using the biography to destroy Mansfield's 'elusiveness' and 'subtlety', which he had brought to the fore in previous works: 'Better to swing anonymously on the gallows than to be neatly

\footnotetext{
116 Wevers, p. 4. Thomas Bracken's The New Zealand Tourist (1879) and C.N. Bayaertz' Guide to New Zealand: The Most Scenic Country in the World (1906) were but two of the most famous guide books available to Murry.

117 This edition does not pretend to offer a comprehensive overview of the critical reception to Life and the Definitive Journal, a task that would require a full analysis of newspapers and journals from around the world. Instead, this section summarises briefly the main themes discernible in the reviews in the G.N. Morris Collection at the Alexander Turnbull Library (MS-Papers-3981-004). Morris, a collector of Mansfieldania, kept a large and meticulous record of English and New Zealand periodical reviews of Life and Journal in several bound volumes and sundry folders.

118 'Katherine Mansfield', The Times, 13 October 1933, p. 20.

${ }^{119}$ M.E.S, 'Katherine Mansfield: Genius and Tragedy', Auckland Star, 16 December 1933, p. 1.

${ }^{120}$ T.I.M., 'Katherine Mansfield and her Genius', Sydney Morning Herald, 30 December 1933, p. 7.

${ }^{121}$ Geoffrey West, 'Katherine Mansfield', Times Literary Supplement, 12 October 1933, p. 686.
} 
docketed and ticketed by the meticulous Middleton Murry'. ${ }^{22}$ Significant is the fact that none of these reviews made the slightest mention of the Urewera Notebook transcriptions, and any consideration of New Zealand generally was bound up in Murry's construction of Mansfield as a 'lonely but exquisite intellect' in her country of birth.

In 1954, when repackaged for the Definitive Journal, the Urewera Notebook material again met with little critical attention, and the few reviews that appeared followed the same themes. Reviewers felt Mansfield's 'sensibility' and 'subtlety' were palpable in the Definitive Journal as a whole, and her New Zealand upbringing at times 'turbulent' and 'discontented', but of the Urewera Notebook these reviews were generally silent. ${ }^{123}$ When in 1958, along with the rest of Murry's material, the Urewera Notebook was acquired by the Alexander Turnbull Library, criticism of Murry's treatment of the camping notes became both strident and specific. As scholars began comparing the original manuscript with the Definitive Journal, they came to the conclusion that Murry's transcription was 'literary synthesis and editorial patchwork' on a massive scale. ${ }^{124}$ Australian scholar Philip Waldron examined the notebook in some detail, and said of it 'a great deal has not found its way into print. Errors must have been obvious to New Zealand readers in the passages that have been accessible to them, even without recourse to the MSS. ${ }^{125} \mathrm{He}$ drew attention to the 'meaningless entry' transcribed in Murry's edition as " Nango (?) whare, in distance Picton". There are no words ending -ngo in Maori in the MS it looks like "Raupo". ${ }^{126} \mathrm{He}$ also pointed out the absurdity that,

Picton is in the South Island of New Zealand whereas Katherine Mansfield is at this stage well up the North Island ... Murry's version is nonsense, and is typical of what happens when he comes across Maori words or place names in the text dealing with the Urewera trip. No one will be able to follow the trip through the eyes of Katherine Mansfield until her account of it is edited accurately and in full. ${ }^{127}$

\footnotetext{
${ }^{122}$ Muriel May, 'The necessity for Suttee', Evening Star, 30 December 1933, p. 6.

${ }^{123}$ Elizabeth Jennings, 'Moments of Feeling', Spectator, 19 November 1954, p. 51.

${ }^{124}$ Ian A. Gordon, 'The Editing of Katherine Mansfield's Journal and Scrapbook', in The Critical Response to Katherine Mansfield, ed. by Jan Pilditch (Westport, CT: Greenwood Press, 1996), pp. 77-82 (p. 78).

${ }^{125}$ Waldron, p. 14.

126 There are in fact Maori words ending in -ngo, for example 'whakarongo' meaning 'to listen, hear or obey'.

${ }^{127}$ Waldron, p. 15.
} 
It was this realisation, together with a suspicion that Murry's portrait of Mansfield had been 'disastrously wrong', which prompted Ian Gordon to reedit and republish the Urewera Notebook. ${ }^{128}$

\section{Ian A. Gordon: The Urewera Notebook (1978)}

\section{i. Ian A. Gordon: Context}

When Murry died in 1954, instructions in his will stipulated that Mansfield's letters and notebooks be offered to the British Museum for $£ 1000$, or for the same price to the Alexander Turnbull Library in Wellington, should the offer to the British Museum be declined. The British auction house, Sotheby's, coincidentally put up for sale a vast quantity of Mansfield's papers, including her notebooks, that same year. A committee of the 'Friends of the Turnbull Library' assembled to negotiate, with the government's financial backing and a public appeal for funds, the purchase of both collections. The Turnbull thus acquired the bulk of Mansfield's papers, including the Urewera Notebook, in one place as a single collection for the first time. ${ }^{129}$ Chairing the Turnbull Committee responsible for the purchase of the manuscripts was Ian Gordon. As committee Chair, Gordon had the privilege of surveying before anyone else the newly acquired papers, unsorted and uncatalogued, and of comparing Murry's transcriptions with original manuscripts. After taking his own copy of the Definitive Journal to the Turnbull and spending 'months comparing it sheet by sheet and page by page with the papers that Middleton Murry had transcribed', Gordon discovered that Murry's Definitive Journal was editorially 'a botched job' and 'no more definitive than Apocrypha'. ${ }^{130}$

Gordon also formed the conviction that Murry's handling of Mansfield's 'Wellington years' had been misleading. Throughout his career, Gordon argued that Murry had been wrong to paint Mansfield as a 'wilful and disgruntled adolescent' in New Zealand. He maintained instead that Mansfield's had been 'altogether a happy childhood', ${ }^{131}$ a fact that was reflected in her fiction where New Zealand was evoked not with 'hatred ... but warmth' ${ }^{132} \mathrm{He}$ had also

\footnotetext{
${ }^{128}$ Ian A. Gordon, 'Katherine Mansfield in the Late Twentieth Century', in The Fine Instrument: Essays on Katherine Mansfield, ed. by Paulette Michel and Michel Dupuis (Sydney: Dangaroo Press, 1989), p. 15-27. ${ }^{129}$ Gordon 1989, p.20.

${ }^{130}$ Gordon 1989, p. 24.

${ }^{131}$ Katherine Mansfield, Undiscovered Country: The New Zealand Stories of Katherine Mansfield, ed. by Ian A. Gordon (London: Longman, 1974), p. ix.

132 Ian A. Gordon, 'Warmth and Hydrangeas: Katherine Mansfield's Wellington Years, 1907-1908', New Zealand Listener, 8 May 1976, p. 23.
} 
concluded of the Urewera Notebook that 'biographers were mistaken when they saw it as yet another gloomy episode, reinforcing "her need to get away". They had been led astray by Murry's shortening of her narrative of the journey, which virtually concludes ... with the anguished entry "this loathsome trip". Her full journal, much of which had never appeared in print, told a different story'. ${ }^{133}$ Gordon's sympathy for the Beauchamp family may have fuelled his view of her early life. Harold Beauchamp was appalled to find himself represented by Murry as the philistine, penny-pinching impediment to Mansfield's talent, and he declared, after her death, 'one man for whom I have the greatest contempt is Katherine's late husband, Middleton Murray, whom I can only describe as a perfect rotter'. ${ }^{134}$ In contrast, the family's relationship with Gordon was one of mutual good will: speaking on the National Radio in 1962, Vera felt she could 'do no better' than refer listeners to Gordon's works, ${ }^{135}$ while Jeanne established a steady correspondence with Gordon, supplying memories, resources and advice to assist his work, and showering him with praise: 'I can only say how grateful I am to you for understanding my Father and Mother'136 ... 'In answer to prayer, you have been sent to tell the truth'. ${ }^{137}$ Thus it was with the conviction that Mansfield had had a supportive and stimulating upbringing that Gordon set about transcribing the notebook afresh, publishing it in 1978 as a stand-alone text entitled The Urewera Notebook.

\section{ii. Ian A. Gordon: Editorial methods}

Gordon reinstated the text that Murry had omitted from Life and the Definitive Journal: The Urewera Notebook reproduces almost every entry that Mansfield made during the camping trip, as well as draft letters (generally unfinished and sometimes scored out), marginalia (usually Maori-English translations) and miscellanea (accounts of expenses, a recipe and a laundry list). It even included the letter (MS-Papers-4026) that Mansfield had torn from the notebook, which Gordon had fortuitously found amongst the mass of loose papers acquired by the Turnbull. Rather than formatting the text to resemble a formal diary, Gordon reproduced it in the unbroken blocks or fragmentary passages according to its appearance in the notebook. He adhered far more closely to the spelling and punctuation of the notebook

\footnotetext{
${ }^{133}$ Gordon 1976, p. 23.

${ }^{134}$ Wellington, Alexander Turnbull Library, MS-Papers-3981-007, Harold Beauchamp to G.N. Morris, 6 December 1937.

${ }^{135}$ Wellington, Oral History Centre at the Alexander Turnbull Library, OHC003422, Interview with Three Sisters of Katherine Mansfield, 1962.

${ }^{136}$ Wellington, Alexander Turnbull Library, MS-Papers-6984-27, Jeanne Renshaw to Ian A. Gordon, 21 August 1977.

${ }^{137}$ MS-Papers-6984-27, Jeanne Renshaw to Ian A. Gordon, 19 January 1978.
} 
than Murry had done, faithfully reproducing Mansfield's grammatical idiosyncrasies. Significantly, he preserved Mansfield's dashes and so captured the sense of swift immediacy of the original notebook entries in passages like 'the Post boy - the children - an accident to the horses - very great - the Maori room - the cushions' (p. 49).

Gordon's version of the notebook was nevertheless manipulated editorially. He removed from the body of entries any material that he felt 'did not form part of the central 'narrative' and relegated it to an appendix of 'Casual Jottings' (p. 91). This 'extraneous' material consisted of annotations that Mansfield had crammed into gaps in the text, usually translations, names and reminders. Gordon arranged this material in lists under 'convenient headings' like 'Place-names', 'Quotations' and 'Maori words and phrases' (pp. 91-2). Gordon's reshuffling of the text carried consequences. It is only through notes like 'In this part of the island 'wh' is ' $\mathrm{f}$ ' ( $\mathrm{p} .93$ ) that Mansfield's attention to the pronunciation of Maori language can be fully appreciated: what Gordon downplayed as 'casual jottings' contained information crucial to understanding Mansfield's attitude to Maori culture. So on the one hand Gordon acknowledged the importance of precisely and comprehensively preserving the true nature of the original through punctuation and coverage, but on the other hand presumed that he could judge subsidiary material dispensable from a real 'narrative' (p. 91). Where Murry strategized to refashion the camping notes into a diary, Gordon's editorial manoeuvring, perhaps unconsciously, accentuated the notebook's self-contained story.

\section{iii. Ian A. Gordon: Contextual aids}

Gordon made unprecedented advances by sourcing historical evidence about the camping trip, which enabled him to contextualise and elucidate his transcription. He unearthed timetables, itineraries, descriptions of the trip as recorded by fellow travellers and housed in various private and public collections throughout the country. These, together with almanacs of the period, tourist handbooks and early survey maps, enabled him to include annotations explaining specific ambiguities in the text, as well as a map locating where the party pitched the tent each night and the route they travelled each day. He also interspersed his transcription with a lengthy commentary 'to supply narrative continuity and offer the necessary background information' (p. 31). His understanding of the itinerary also enabled him to judge with fair accuracy the events and places that Mansfield's entries described, and so reunite dispersed entries and rearrange the text into an intelligible sequence. Gordon's sequence of entries was arbitrary: he arranged the text into what he suggested was its order of 
composition, which fitted neatly with his itinerary. He did not indicate to readers how his sequence of entries differed from that of the original manuscript. Nor did he explain how he had been able to deduce its order of composition with such confidence. Indeed, an assessment of the original manuscript shows that there was little evidence for assertions like ' $[t]$ hat evening she wrote ... a draft letter' (p. 61), as it was impossible for Gordon, or anyone else, to know precisely when individual entries were made. Nevertheless, Gordon's has been the only previous edition of the notebook in which Mansfield's entries could be understood with a degree of narrative coherence.

As noted, Gordon's motive in publishing the Urewera Notebook extended beyond editorial authenticity or narrative consistency. He sought to discredit notions that Mansfield was a 'moody and disgruntled adolescent' (p. 12) on her return to New Zealand and in the introduction to his edition set down his argument baldly: Mansfield, so he said, 'saw in the travelling and camping adventure an opportunity to expand her experience and explore a technique of observation and reportage' and spent the trip 'vigorously enjoying herself' ( $p$. 20). Yet even a superficial reading of the notebook casts doubt on this argument. Mansfield did her fair share of moaning, as when she found herself being 'eaten with mosquitos' (p. 51) or 'tired to death with a headache and thoroughly weary feeling' (p. 69). Gordon systematically minimised evidence of Mansfield's wretchedness by way of dismissive sidecomments: the most flagrant example occurs when Mansfield describes herself in Rotorua as 'so ill' (1. 385), 'depressed' (1. 564) and 'fearfully low' (1. 394), yet Gordon insists Mansfield was energetic and enthusiastic throughout the trip 'apart from a few days of sickness' (p. 20) at Rotorua. Gordon reinforced this interpretation through his commentary, which slid subtly from factual explanation to subjective interpretation. When describing the terrain between $\mathrm{Te}$ Pohue and Tarawera, Gordon noted the day's itinerary, the distance travelled and the safety measures taken in steep sections of the track, but added a positive coda by way of conclusion:

$\mathrm{KM}$ at nineteen was a fit young woman - there must have been at least a dozen miles of walking called for and a total upwards climb on foot of between 2,000 and 3,000 feet. Her enjoyment of the whole day, with its concluding bathe in a hot mineral bath in the evening, is manifest (p. 40).

In this manner Gordon, perhaps no less than Murry, manipulated the reader's interpretation of Mansfield's notebook, by couching her text within his own interpretative observations. 
Indeed, Gordon's attention to technical and circumstantial authenticity obscured the manner in which even his editorial judgments were determined by his agenda. In his determination to cast Mansfield's camping trip in a positive light, Gordon took issue with what he cited as one of Murry's 'key misreadings', ${ }^{138}$ the passage from the Definitive Journal that read: 'Rotarua [sic] - that little hell' (p. 25). He argued that the final word should have been transcribed as 'hill', and claimed that the single word 'hell' constituted one of Murry's greatest blunders as it 'firmly established the conception of KM as an unhappy young woman on her return to New Zealand' (p. 19). Yet to view the original manuscript is to recognise that the word's internal letters are indistinguishable: Gordon could no more offer a definitive reading than Murry. ${ }^{139}$ Even the point at which Gordon ended his transcription also suggests an intention to end Mansfield's 'story' on a high note. Gordon concluded his transcription with Mansfield's entry describing her return train journey to Wellington, and specifically with the words 'I look perfectly charming' (p. 90). In fact this entry continues with Mansfield describing a book she was reading: 'And I read a little book called The Book of Tea - it is wholly adorable' (11. 726-7). Presumably Gordon felt the gush over the book detracted from his picture of Mansfield as 'a very poised and secure young woman' (p. 90) by the end of the camping holiday.

\section{iv. Ian A. Gordon: Critical reception}

Soon after its publication, a perceptive review of The Urewera Notebook appeared in the Listener. Vincent O'Sullivan, the reviewer, questioned the accuracy of Gordon's transcription: 'I compared only half a dozen pages directly with the original, but even in that space misreadings were frequent ... "I bought presents in Whaka" for "afternoon in Whaka"'. ${ }^{140}$ O'Sullivan also questioned 'the curious liberty Gordon has taken in dividing the text at times quite arbitrarily', feeling that Gordon's tacit rearrangement of text and insertion of a running commentary 'reads very well, but it does not quite read as Mansfield wrote it' ${ }^{141}$ O'Sullivan's most strident criticism related to the 'revisionist' reading of Mansfield's Wellington life that Gordon championed in his introduction:

I am also in doubt about the kind of young woman who emerges from the prefatory "reassessment" of Mansfield's Wellington years. What

\footnotetext{
138 Gordon 1989, p. 25.

${ }^{139}$ See 1. 373n.

${ }^{140}$ Vincent O’Sullivan, 'Glimpses Through the Smoke-screen', New Zealand Listener, 19 May 1979, pp. 64-5.

${ }^{141}$ O’Sullivan 1979, pp. 64-5.
} 
the editor very much wants is a normal girl, hard-working, even fairly contented. But Mansfield simply will not scrub up into a dutiful daughter who was occasionally a little fractious but who was by and large very sensible about important things ... The evidence is amply there, in both published and unpublished notes and letters, that Mansfield was difficult, discontented and frequently angry during this period in Wellington. Her father much later agreed that "she was in rebellion" ... That she enjoyed the camping holiday is not enough to reduce her to a "normal" teenager. Even in this notebook, which is mostly about her own feelings at various places she visited, the gimlet-eyed girl we expect flares out. ${ }^{142}$

O'Sullivan's was something of a lone voice, however, as The Urewera Notebook received little critical attention. In fact, Gordon's editorial methods have never been systematically challenged until now, and the notebook's next transcriber, Margaret Scott, approached the task substantially in agreement with Gordon's interpretation of the text: 'Professor Gordon was' she later wrote, 'the first to point out that the picture of the wretchedly unhappy adolescent was false'. ${ }^{143}$

\section{Margaret Scott: The Katherine Mansfield Notebooks (1997)}

\section{i. Margaret Scott: Context}

A decade after Gordon had overseen the Turnbull's acquisition of the Urewera Notebook, the position of Manuscripts Librarian at the Turnbull was filled by Margaret Scott. Like Murry's, Scott's life was shaped by Mansfield's literary legacy. In her biography Scott described the parallels she saw between Mansfield's life and her own: 'catastrophe' struck both women at a similar age as Mansfield died of tuberculosis at 35 while Scott became a widow at $32 .{ }^{144}$ In moments of trouble, Scott felt that she and Mansfield shared an almost preternatural empathy: reading Mansfield's diary entries in an hour of despair, Scott felt they were 'mysteriously meant for me'. ${ }^{145}$ Scott credited Mansfield with being the 'raft ... that carried me to dry

\footnotetext{
142 Ibid.

${ }^{143}$ Scott 2001, p. 153.

${ }^{144}$ Scott 2001, p. 7.

145 Scott 2001, p. 67.
} 
land' ${ }^{146}$ because Mansfield's literary legacy afforded her a career in transcription, and salvation from depression and destitution. Scott surrounded herself with the characters of Mansfield's life: she lived briefly with Ida Baker, visited Murry's fourth wife, Mary, and Mansfield's sisters, Jeanne and Vera. She also surrounded herself with Mansfield's belongings: she received Mansfield's copy of Milton poems from biographer Antony Alpers; Ida Baker gave her Mansfield's shawl, pearl broach and typewriter. Scott's preoccupation with Mansfield even determined the naming of her youngest daughter, whom she called Katherine in memory of 'the guiding angel' of her life. ${ }^{147}$

Scott made three successive forays into Mansfield's manuscripts. Firstly, over nine years she transcribed sections of a journal that Mansfield had filled during 1906 and 1907 which the Turnbull published between 1970 and 1979 in consecutive issues of The Turnbull Library Record. Secondly, she was awarded the Menton Fellowship in 1970, enabling her to assemble and transcribe Mansfield's collected letters. In collaboration with Vincent O'Sullivan, she then published The Collected Letters of Katherine Mansfield, in five volumes, from 1984. Thirdly, Scott returned to the notebooks, being

aware that critics, commentators, students and others were attempting to read these manuscripts and relying too much on guess-work, while at the same time Murry's misreadings were being quoted and perpetuated in other people's books. I developed a wish to do the whole thing again from the beginning, leaving out nothing (Notebooks, xiv).

Scott therefore successfully applied for a New Zealand National Library Research Fellowship in 1988, which enabled her to transcribe the 46 notebooks in the Turnbull's collection. Thus in 1997 the Urewera Notebook was transcribed and published for a third time, as part of a two-volume transcription of all journals and unbound papers held at the Alexander Turnbull Library entitled The Katherine Mansfield Notebooks: Complete Edition.

\footnotetext{
${ }^{146}$ Scott 2001, p. 7.
}

${ }^{147}$ Scott 2001, p. 172. 


\section{ii. Margaret Scott: Editorial methods}

Scott felt she was capable of 'building on and improving' the work of previous editors by delivering a more sensitive and precise transcription. ${ }^{148}$ She considered that previous editions had been 'flawed ... seriously so' since 'reading Mansfield's script took years of practice as well as a bit of flair' ${ }^{149}$ In her autobiography Scott proclaimed her ability to correct the mistakes of Murry and of Gordon, citing the example of a particularly indistinct sentence which Gordon had read as 'a wave of cold air strikes her - lays cold fingers about her heart it is the shadow from Pohataroa' (p. 75). Murry had simply omitted the phrase from the Definitive Journal, and Scott was convinced that Gordon's reading was incorrect. She 'photocopied that page with the copier set at its maximum contrast level to try to bring up the pencil marks', and went home, 'telling myself that I was not permitted to read at mealtimes until I had solved the puzzle of that word, even if it meant I could not read another book in my life'. As a result of such intense scrutiny, in a flash of insight Scott recognised that the 'wave of cold air' was not 'the shadow from Pohataroa' but 'the wizard London'. 150

Such dedication paid off, as Scott's transcription of the Urewera Notebook was as complete as Gordon's, yet more technically accurate at the level of individual words and sentence structure than either Murry or Gordon's editions. She deciphered numerous previously unidentified phrases, and followed even more strictly than Gordon the precedent of remaining faithful to the eccentricities of the original document. ${ }^{151}$ When Mansfield's spelling was obviously incorrect, as in 'Accomodation House' (1. 167), Scott faithfully reproduced the mistake. Unlike Murry and Gordon, Scott retained Mansfield's ampersands because she believed that would 'convey the breathlessly shorthand nature of early jottings' (p. xvi). Gordon, who in other respects had staunchly retained original punctuation, destroyed all sense of hasty reportage in phrases such as 'ham sandwiches and cups and saucers' (p. 34), which Scott recaptured by retaining the symbol in lieu of the word: 'ham sandwiches \& cups \& saucers' (p. 136).

\footnotetext{
${ }^{148}$ Katherine Mansfield, The Katherine Mansfield Notebooks, ed. by Margaret Scott (Lincoln; Wellington: Lincoln University Press and Daphne Brasell Associates, 1997), p. 134.

${ }^{149}$ Scott 2001, p. 141.

${ }^{150}$ Scott 2001, pp. 157-158.

${ }^{151}$ Although Scott 's transcription is more accurate than those of Murry or Gordon's in its attention to Mansfield's spelling, I nevertheless disagree with several of her readings. See for instance my reading of 'lovely' (1.323) where Scott reads 'lonely' and my reading of 'lake' (1. 347) where Scott reads 'rape'.
} 
Despite the advantage that Scott's transcription was in many respects more technically accurate than Murry or Gordon's, it should be approached with a similar caution as its predecessors. In her introduction to The Katherine Mansfield Notebooks Scott stated that 'while, unlike Murry' she had been strict about not supplying exclamation marks, question marks, colons and semi-colons and had 'left the text, on the whole, under-punctuated' she had used her own judgements about the 'real' nature of Mansfield's dashes:

In her early notebooks she was scribbling so fast that the only form of punctuation she used was a dash. A dash was quicker and easier to make than a backward-turning comma or a stationary full stop ... Since many of these dashes function as commas or full stops I have rendered them so, but where they function as dashes I have of course kept them (p. xvi).

Scott's confidence about her ability to 'interpret' Mansfield's dashes as commas and full stops led her paradoxically to tidy but taint her transcription. Where Mansfield wrote 'Mrs Warbrick is such a picture in her pink dressing gown her wide elastic hat her black fringe the hands are like carving' (11. 306-8) Scott transformed a passage which Mansfield had not bothered to punctuate at all into more conventional, elegant prose: 'Mrs Warbrick is such a picture in her pink dressing gown, her wide elastic hat, her black fringe. Her hands are like carving' (p. 141). Despite her exalted intentions, Scott's editorial methods inevitably led her to act as a subjective 'filter' of Mansfield's voice.

\section{iii. Margaret Scott: Contextual aids}

Scott claimed to face discrimination in her professional career because she was not an academic and had to battle the presumption that 'academics know more than nonacademics'. ${ }^{152}$ However, her transcription of the notebook did suffer from the absence of the scholarly apparatus and the contextual referencing necessary to produce a useful edition. She presented her transcription with a mere 25 footnotes, providing cursory explanations of people mentioned, Maori words and editorial ambiguities. Moreover, Scott presented her transcription in page order - that is, in the same chaotic, disrupted sequence in which the text is arranged on the pages of the original manuscript. Rather than follow Gordon's precedent of reuniting dispersed entries and arranging entries into a meaningful sequence, her transcription

${ }^{152}$ Scott 2001, p. 159 
reads as a perplexing jumble to the uninformed reader. Scott's decision to reproduce the text in page order without elucidating her transcription through annotations ironically led her to reintroduce into her edition some of the key flaws of Murry's Definitive Journal: in Scott's hands, Mansfield was once again a mysterious character describing an enigmatic series of incidents, but this time interrupting her entries at random to insert translations, lists, and other unrelated entries.

\section{iv. Margaret Scott: Critical reception}

Scott herself admitted that 'post-publication attention [to The Katherine Mansfield Notebooks] in New Zealand was disappointing', but that 'extensive and prominent reviews' appeared in the London Review of Books and the Times Literary Supplement. ${ }^{153}$ These reviews praised Scott for allowing Mansfield to be viewed 'off her guard and unexpurged, for the first time', ${ }^{154}$ while not overlooking the fact that 'her line on punctuation is distinctly interventionist'. ${ }^{155}$ More recent scholarly criticism has extended doubts around Scott's claims to offer absolute editorial authenticity. Anna Jackson has pointed out that The Katherine Mansfield Notebooks 'by its very presentation, promotes a reading of it as if it were the diary Mansfield never really kept'. ${ }^{156}$ Items that Mansfield squashed into margins or inserted in empty spaces at later dates are given equal weight in Scott's transcription as the 'main' entries, so for all Scott's desire to be literal, her transcription loses the 'spatiality' of the original. Jackson has questioned whether the portrayal of Mansfield that emerges from Scott's transcriptions, a 'KM who moves from the poetic mode to the mundane, almost in the same breath ... a KM who scribbles flights of fancy in amongst her shopping lists' is 'necessarily more valid than the portrayal of the Journal, even if it is more complete'. ${ }^{157}$

\section{Conclusion}

Jackson's observation that Murry's and Scott's transcriptions both "present very different ... portraits of the Mansfield 'self"" points to the inevitable fact that whether striving to produce the near-diplomatic transcription of Scott at one extreme, or the carefully doctored version of Murry at the other, an editor cannot expect to avoid introducing a degree of interpretation into

\footnotetext{
${ }^{153}$ Scott 2001, p. 164.

${ }^{154}$ Elizabeth Lowry, 'Pull up Now Yourself: Two Parts Tragedy and Two Parts Comedy', Times Literary Supplement, 19 March 1999, pp. 3-4.

${ }^{155}$ Lorna Sage, 'I, Too, Write a Little', London Review of Books, 18 June 1998, pp. 9-10.

${ }^{156}$ Anna Jackson, 'The Notebooks, Journal and Papers of Katherine Mansfield: Is Any of this her Diary?', Journal of New Zealand Literature, 18-19 (2001), 83-99 (p. 93).

157 Jackson, p. 96.
} 
the text. ${ }^{158}$ Following the publication of Scott's edition, the Turnbull has digitised the notebook. ${ }^{159}$ While this would seem to amount to 'objective' reproduction, the difficulties of understanding the manuscript - its chaotic sequence and Mansfield's almost illegible writing - render the notebook scarcely more intelligible in manuscript form. It is inevitable that our understanding of Mansfield will be influenced by vagaries and constraints of those who edit and publish her writing; to acknowledge this does not diminish the worth of new editions of her work, but ought to fuel debate about the girl who speaks to us from the pages of her camping notebook.

158 Jackson, p. 84.

159 <http://tapuhi.natlib.govt.nz/cgi-bin/spydus/FULL/ARCHIVESNR/OPHDR/14/15152,1> [accessed 22 April 2014]. 


\section{$\underline{\text { Editorial Procedures }}$}

This edition is based on my own transcription of the Urewera Notebook. I have endeavoured to preserve for readers the appearance and spirit of Mansfield's notebook as faithfully as the medium of print will allow. To this end, Mansfield's misspellings and idiosyncratic capitalisation have been retained. Similarly, her ampersands, numerals and underlining have been reproduced as she wrote them, as well as her occasional false starts and the omission or repetition of words. Mansfield's unconventional and incessant use of dashes poses one of the greater challenges to transcription. These dashes appear where one would expect to find commas or full stops, and they assume various shapes, lengths and positions above and below the printed line. I have represented all such marks as spaced en-dashes, without presuming to translate them into other forms of punctuation. I have ignored dashes only when they are so small and faint as to appear inadvertent, on the assumption that they are marks formed as Mansfield abstractedly rested her pencil on the paper.

I have emended my transcription as lightly as possible. I have silently regularised occasionally mismatched quotation marks, although Mansfield's choice of single or double quotation marks is unpredictable and I have not presumed to alter these. As a parenthesis, Mansfield used a unique symbol, something between a square bracket and a capital letter ' $\mathrm{J}$ '; to differentiate these from editorial comments, Mansfield's parentheses have been represented as round brackets. Where I have found a word impossible to decipher, 'illegible' appears in italics within square brackets thus: [illegible]. Doubtful readings are enclosed in square brackets and preceded by a question mark: [?house]. Mansfield's deletions are represented by means of a strike-through: Fuesday. Deleted text that I have been unable to decipher appears thus: [deleted words illegible]. Phrases introduced by Mansfield above or below the line have been inserted into the sentence where appropriate and are indicated by enclosing caret marks: the $\left({ }^{\wedge}\right) \operatorname{very}\left({ }^{\wedge}\right)$ incarnation of evening.

The presentation of Mansfield's muddled entries presents particular challenges. The narrative incoherence that results in presenting the text according to original page layout (as was Scott's approach), would be difficult to remedy even with the aid of an extensive scholarly apparatus. Presenting the text in order of its composition is impossible, given that many of Mansfield's notes are undated and even those entries that are in some way linked to a 
particular place or day of the week were possibly written in hindsight. I have instead reunited entries and arranged them so as to offer readers maximum narrative continuity: Irrespective of whether entries were written in hindsight, or contemporaneously with the events described, they are positioned so as to form a sequence that matches, as far as possible, the itinerary. This is roughly the approach that Gordon adopted, but as my itinerary differs in some respects from his, so too the sequence of entries in this edition differs from that of The Urewera Notebook (1978). Where marginalia or stray lists interrupt a longer entry, I have reproduced them in the commentary, where their placement in relation to the main entry is explained. I have also introduced paragraph breaks between entries written on different days, but have otherwise attempted to reproduce Mansfield's own unbroken blocks of text, and imitated the format of her 'title page', lists and letters.

The collation is situated immediately after the transcription on every page. This lists variant readings from previously published transcriptions of the notebook and is linked to the text by numbers and key words. The keyword is quoted, followed by a closing square bracket, and to the right of the bracket all variant readings are listed in publication order with their sources. Thus, the following example indicates that my reading of 'huia' at 1.191 concurs with the transcriptions of Gordon and Scott, but that Mantz and Murry read the same word as 'tui' in Life, while Murry read it as 'blue' in the Definitive Journal:

191 huia] G, S, tui MM, blue M;

In the next example, both Gordon and Scott read 'marvellous', but 'meet Maoris' is my own reading of the same phrase:

351 meet Maoris] marvellous G, S;

A record of every variant reading, whether accidental or substantive, significant or slight, would be colossal and of questionable use. Accidental variations tend to arise as a result of each editor's general policy of transcription rather than his or her exacting attention to Mansfield's punctuation, and there are also a myriad of minor variant readings between Murry's transcriptions and subsequent editions. Therefore this edition lists key substantive variants. 
I have adopted two different methods of registering text omitted from previous editions. Both Life and the Definitive Journal omit large sections of text, so where variant readings are not listed from these transcriptions, the reader can assume that Murry did not include the word(s) in his transcriptions. So in the following example, Murry omitted the words 'strong blue' in from both Life and the Definitive Journal:

228 strong blue] G, stone colour $\mathrm{S}$;

In another example, Murry included the words 'mile upon mile' in the Definitive Journal, but not in Life, thus:

231 mile upon mile] $\mathrm{M}, \mathrm{S}$, river upon river $\mathrm{G}$;

On the far fewer occasions when Gordon or Scott omitted text from their transcription, this has been indicated, to avoid giving the impression that a variant reading has been excluded accidentally:

287 Rangateiki] Rangitaiki G, om. S;

The commentary sits beneath the collation. In addition to marginalia, these notes offer a condensed survey of significant attempts to elucidate and interpret words, phrases or whole passages of the 'Urewera Notebook', together with the fruits of my own research. This too is linked to the text by line number and key word(s). Owing to my heavy reliance on historical resources which describe distances in terms of feet and miles, imperial units have been adopted in the commentary, as in this edition as a whole. The spelling of place-names also warrants explanation: Maori place-names were spelt in a variety of ways in 1907 in newspapers, official documents and private records: for instance, Te Pohue was formally known as either 'Pohui'or 'Pohue' until 1910, when its name was officially altered to Te Pohue. ${ }^{160}$ For consistency I have adopted modern standard place-names as classified by the New Zealand Gazetteer of Official Geographic Names.

\footnotetext{
${ }^{160}$ Patrick Parsons, In the Shadow of Te Waka: The History of the Te Pohue District (Napier: Te Pohue History Committee, 1997), p. 6.
} 


\section{Biographical Register
Camping Party}

GEORGE EBBETT (1872-1954), the eldest child of Irish immigrants, had studied law by correspondence and been admitted to the bar in 1896. ${ }^{161}$ By 1907 he was a figure of rising provincial importance: he combined legal work in central Hastings with sheep farming, served as a Borough Councillor and People's Churchwarden, ${ }^{162}$ owned race horses, played champion tennis and was secretary of the Hawke's Bay County Football Club. ${ }^{163}$ He had also purchased 'valuable town and suburban properties' in Hastings and had amassed a number of rural sections throughout Hawke's Bay. ${ }^{164}$ In the decades following the camping trip, Ebbett gained prominence in local politics, eventually serving as Mayor of Hastings between 1919 and 1921. In this course of his legal practice and land purchases, Ebbett developed relationships with a number of local Maori. By 1907 he was considered 'well-versed in Maori lore' and had accumulated a large library of Maori history and ethnography. ${ }^{165} \mathrm{He}$ had also begun collecting Maori ‘curios', a ‘consuming passion' which by 1907 had already led him on a number of camping expeditions throughout the North Island. ${ }^{166}$

ELIZA MAUD EBBETT (1879-1934) was the daughter of a Napier grocery merchant, and had married George Ebbett in 1900. By 1907 she had three children, the youngest of whom was barely a year old.

(?) HILL (N.D.), a Hastings farmer, was probably known to George Ebbett through mutual agricultural interests. He had been 'hired to drive the horses' but 'preferring to be a member of the party, he accepted no payment'. ${ }^{167}$

\footnotetext{
${ }^{161}$ M. B. Boyd, City of the Plains: A History of Hastings (Wellington: Victoria University Press for the Hastings City Council, 1984), p. 287.

162 Special Correspondent, 'Provincial Centres', Dominion, 6 December 1910, p. 2.

163 Untitled, Hawke's Bay Herald, 17 April 1895, p. 2.

164 Boyd, 287.

165 Boyd, 287.

${ }^{166}$ Hawke's Bay, Hawke's Bay Cultural Trust/Ruawharo Ta-u-Rangi, Ebbett Collection Display Panel.

${ }^{167}$ MS-Papers-4010.
} 
ANNIE BLAIR PURDIE LEITHEAD (1880-1966) was born in Scotland. Her father, a Selkirkshire farmer, had come to New Zealand in 1886 and by 1904 was manager of the Oruawharo Station in the central Hawke's Bay. ${ }^{168}$ Annie, whom Elsie Webber described as a 'very sweet woman', was unmarried at the time of the camping trip. ${ }^{169}$

MARGARET (MILLIE) AMEILA PARKER (1882-1958), had secured KM a place in the 1907 camping party. ${ }^{170}$ She had met the Ebbetts through her cousin Harry Parker, a national tennis champion who competed regularly with Ebbett in regional sporting events. ${ }^{171}$ Millie was the daughter of William Parker, a Wellington pharmacist, and the niece of Robert Parker, a 'respected and revered' conductor and musician. ${ }^{172} \mathrm{KM}$ and Millie had met through their mutual acquaintanceship with the Trowell family: in early 1907 Arnold Trowell, then studying in Brussels, sent a trio composition to his father, who invited KM and Millie to join him in performing the piece. ${ }^{173}$ Two years after the camping trip, Millie studied music in London. ${ }^{174}$ She returned to New Zealand several years after this to establish herself as a music teacher Wellington and Auckland. ${ }^{175}$ Millie's success in a 1928 national short story competition with 'The Sphinx', a tale of two girls' encounter with mythic creatures in the heart of the Urewera bush, is evidence that Millie recalled KM, and their camping trip, all her life. ${ }^{176}$

HERBERT JAMES WEBBER (1877-1949) was a well-established pharmacist by 1907, occupying a two storey wooden building in central Hastings known as 'Webber's Corner'. ${ }^{177}$ He met George Ebbett through their mutual involvement in the Hawke's Bay Tennis Club and presumably through the proximity of their central city premises. ${ }^{178}$

ELSIE SARAH WEBBER (1885-1956), née MacDonald, had married Herbert Webber in January 1907. The youngest member of the camping party aside from KM herself, she

\footnotetext{
168 'Personal Items', Dominion, 12 February 1915, p. 5.

${ }^{169}$ MS-Papers-4010.

${ }^{170}$ MS-Papers-4010.

171 'All Sorts of People', Free Lance, 2 December 1905, p. 3.

172 'Obituary', Evening Post, 20 February 1937, p. 11.

${ }^{173}$ Millie A. Parker, 'Broken Strings', New Zealand Herald, 3 February 1923, p. 1.

174 ‘About People: Notes from London, New Zealanders' Successes', Evening Post, 12 January 1909, p. 3.

175 ‘Advertisements', Auckland Star, 27 January 1934, p. 6.

${ }^{176}$ Margaret A. Parker, 'The Sphynx', Auckland Star, 12 May 1928, supp. p. 7.

177 Press Association, 'Fire at Hastings', Poverty Bay Herald, 4 April 1910, p. 5.

178 ‘Tennis', Bush Advocate, 17 April 1906, p. 8.
} 
recalled spending much of the trip in KM's company. She professed to liking KM 'very much' and being treated 'kindly' by her. ${ }^{179}$

${ }^{179}$ MS-Papers-4010. 


\section{$\underline{\text { Itinerary }}$}

\section{Length of the camping trip}

There can be no certainty about the route and timetable adopted by Mansfield's camping party. In addition to the notebook itself, the Turnbull houses letters and newspaper articles pertaining to the camping trip, written by various members of the party between 1931 and 1956. These records contain a multitude of contradictions and omissions. Millie Parker, for instance, writing in 1931, recalled that the campers headed north from Rangitaiki and after 'a very strenuous time crossing the Kaingaroa Plains ... arrived at last at Te Whaiti, on the edge of the Urewera Country'. ${ }^{180}$ Yet in 1956 Elsie Webber remembered reaching the Urewera from a different direction: 'After Rotorua, we went to Te Whaiti' ${ }^{181}$ It is vexing that neither of these women (nor any of the other campers) left an account of what occurred when the party reached the Urewera heartland. Even the duration of the trip the campers later disputed: when Elsie Webber was asked how long the trip lasted, she replied: 'Miss Leithead thinks it was more than three. I thought it about three'. ${ }^{182}$

In the publications produced since Mansfield's death, there has come to be a general consensus that the journey lasted one month. In Life, Mantz and Murry described the journey as lasting 'six weeks' (p. 307). In the Definitive Journal Murry amended this to one month: the trip, he said, lasted 'from November 15 to December 17' (p. 22). Murry never gave evidence for his dates, yet his schedule appears to have become authoritative: Gordon adopted Murry's dates, although he conceded that doing so was 'problematic' and he was forced to conclude that the party 'must have spent a full week at Taupo' (p. 81) in order to make those dates fit, a conclusion for which he had little justification. None of the archival material mentions a prolonged stay in Taupo. Subsequent editors and biographers have nevertheless adopted the itinerary estimated by Murry and accepted by Gordon, agreeing that it was a 'four-week camping trip', ${ }^{183}$ beginning about ' 18 November'. ${ }^{184}$

\footnotetext{
${ }^{180}$ Margaret A. Parker, 'A Summer Day in 1907', New Zealand Herald, 4 April 1931 p.6.

${ }^{181}$ MS-Papers-4010.

182 Ibid.

${ }^{183}$ Scott 2001, 157.

184 Jones, 75.
} 
In fact, my research when considered in tandem with the Turnbull's records, leaves sections of the route uncertain but does provide compelling evidence that the trip took less than one month. Elsie Webber recalled that she had been invited 'on a camping trip ... to take three weeks', ${ }^{185}$ and George Ebbett asserted that it had been 'a three weeks' camping trip'. ${ }^{186}$ On 23 November 1907 the Dominion reported: 'Miss Kathleen Beauchamp leaves this morning for a camping excursion to the Hot Lakes District'. ${ }^{187}$ Although she expected 'to be away about five weeks' ${ }^{\text {'18 }}$ on 18 December the newspaper announced 'Miss Kathleen Beauchamp returned last night'. ${ }^{189}$ Allowing for one overnight stay in Hastings one the outward journey, and two nights in Hastings after the return, this allows a three-week trip. Moreover Gordon admitted that the notebook was 'the only account which was kept day by day' and stated that its dating was 'demonstrably accurate and precise' (p. 81) and so it is significant that Mansfield's entries account for only 21 days' travel. It is safe to assume that the camping holiday, which was to leave such a lasting imprint in the minds of all those concerned, lasted little more than three weeks.

\section{Description of events}

\section{Saturday, 23 November (Wellington to Hastings)}

Mansfield and Millie Parker left Wellington by an early morning train - probably departing at 8:22 a.m. - bound for Hastings. ${ }^{190}$ After passing through the Hutt Valley, the tightly regulated journey allowed for a five-minute stop at Kaitoke at 9:41 a.m., where a refreshment room offered counter food standardised by strict New Zealand Government Railways guidelines. The train then mounted the steep Rimutaka Mountain Range, offering en route 'magnificent views of the gorges' and precipitous scrubland, before descending into the farming country of the Wairarapa. ${ }^{191}$ Passengers disembarked at 2.09 p.m. at the town of Woodville, where a restaurant-style refreshment room provided a hasty lunch. The two girls then caught a connection for Hastings, probably that of the mail train at 2:29 p.m. and arriving at Hastings

\footnotetext{
185 MS-Papers-4010.

${ }^{186}$ Wellington, Alexander Turnbull Library, MS-Papers-7293-12, George Ebbett to P A Lawlor, 3 March 1957.

187 'Social and Personal', Dominion, 23 November 1907, p. 11

188 Ibid

189 'Social and Personal', Dominion, 18 December 1907, p. 3.

${ }^{190}$ Hawke's Bay Almanac (Napier: James Wood at the Hawke's Bay Herald Office, 1908), p. 181.

${ }^{191}$ Marama, 'Tourist Resorts of the Colony', Auckland Star, 1 December 1906, p. 9.
} 
at 6:16pm. ${ }^{192}$ They spent their first night away with Millie Parker's relations, George and Eliza Ebbett, who lived in central Hastings a short distance from the railway station. ${ }^{193}$

\section{Sunday, 24 November (Hastings to Eskdale)}

The following morning all remaining members of the camping party assembled at the Ebbetts' home. Elsie Webber recalled that, after being introduced to the 'two travelling companions from Wellington', they left Hastings with 'a coach to travel in, and what we called the 'commissariat' - a dray to take provisions and camping equipment, which was covered over with a tarpaulin'. ${ }^{194}$ The party went northwards, through the nearby town of Napier to Eskdale, by then an 'outlying farming settlement' where much of the valley had been transformed by settlers into 'cropping and grazing ... and sheep-carrying country'. ${ }^{195}$ By 1907, George Ebbett was engaged in legal negotiations to purchase a 290 acre block of Maori-owned land bordering the willow-lined Esk River, not far from a Ngati MatepuWhakaari settlement. ${ }^{196} \mathrm{He}$ had leased and farmed the block since $1904,{ }^{197}$ and it was probably on this land that the party pitched their tent on their first night.

\section{Monday, 25 November (Eskdale to Te Pohue)}

The next three days were spent following the Napier-Taupo Road across the immense mountain ranges that separate Hawke's Bay from the Central Plateau. The road led inland through the Esk Valley, ${ }^{198}$ before ascending 'very steep ... hills and some fine pastoral country'. ${ }^{199}$ The day's destination was Te Pohue, a saw-milling settlement twenty-six miles from Napier. The small town, which comprised a storehouse, a blacksmith, a post office, a school, accommodation houses and several timber mills, stood amidst native bush, which had

\footnotetext{
192 Hawke's Bay Almanac (Napier: James Wood at the Hawke's Bay Herald Office, 1908), p. 181.

193 MS-Papers-4010.

194 Ibid.

${ }^{195}$ The Cyclopedia of New Zealand: Industrial, Descriptive, Historical, Biographical Facts, Figures, Illustrations, 6 vols (Wellington: Cyclopedia Co., 1908), 6, pp. 419-20.

196 Waitangi Tribunal The Mohaka ki Ahuriri Report (Wai 201, 2004) 1, pp. 153-4.

${ }^{197}$ Department of Maori Affairs [record group] (ACIH), George Ebbett, Hastings. - Subject: Petane blocks. No. [Number] 2 and Lots 2 and 3 sub 3 of no. [Number] 3, Series 16036, 1906/351, Archives New Zealand (ANZ). ${ }^{198}$ Mansfield inaccurately called this the 'Petane Valley' (1. 84) owing to the nearby Petane region (now known as Bay View).

199 The New Zealand Official Year-Book 1907:

<http://www3.stats.govt.nz/New_Zealand_Official_Yearbooks/1907/NZOYB_1907.html> [accessed 15 April 2014]
} 
once swathed the region but by 1907 was severely reduced. Although it was rural and rather rugged, the area was still familiar territory to many of the campers: Eliza Ebbett's brother-inlaw was the manager of the nearby Ohurakura Station, ${ }^{200}$ and Elsie Webber later remarked: 'Pohui was very well known to me, for I had often spent holidays there'. ${ }^{201}$ Upon arrival, Mansfield expressed a wish 'to see some real N.Z. bush before leaving for England' and so Elsie Webber led her and Millie Parker to 'some pretty parts' ${ }^{202}$, following a track that led from the main road through the Ohurakura Bush, to the homestead of the Ohurakura Station. ${ }^{203}$ Upon returning to the camp several hours later, the young women found that the other campers, somewhat chagrined, had spent the time labouring over the dinner which was 'just ready to be eaten'. ${ }^{204}$

\section{Tuesday, 26 November (Te Pohue to Tarawera)}

The route between Te Pohue and the next campsite at Tarawera (not to be confused with Mount Tarawera near Rotorua) covered twenty-one miles of mountainous terrain. The 'circuitous sideling road' wound up two mountain ranges: the Titiokura Saddle and the immense Turangakumu Mountain Range. At 2,650 feet above sea level the Turangakumu summit offered 'a fine comprehensive view of the Hauraki Gulf' and surrounding country. ${ }^{205}$ George Ebbett had secured a fifth horse at Te Pohue to help with the arduous climb, but Elsie Webber recalled nevertheless, 'we had to get out and walk over the hills to spare the horses' ${ }^{206}$ Another climb was made to Te Haroto, the site of 'a native school and settlement' ${ }^{207}$ before the road descended to the Waipunga Stream and brought the campers at last to Tarawera. This little settlement had been one of the 'old constabulary camps in the time of the Maori war', ${ }^{208}$ but in 1907 it boasted only a post-office-cum-hotel and a permanent population of $19 .{ }^{209}$ One of its main attractions, a mile's walk from the hotel, was the natural hot spring that Mansfield's party visited that evening.

\footnotetext{
${ }^{200}$ Parsons, p. 93.

${ }^{201}$ MS-Papers-4010.

202 Ibid.

${ }^{203}$ Parsons, p. 92.

${ }^{204}$ MS-Papers-4010.

205 Marama, 'Tourist Resorts of the Colony', Auckland Star, 1 December 1906, p. 9.

${ }^{206}$ MS-Papers-4010.

${ }^{207}$ Marama, 'Tourist Resorts of the Colony', Auckland Star, 1 December 1906, p. 9.

208 Ibid.

${ }^{209}$ Results of a Census of the Colony of New Zealand Taken for the Night of the 29th April, 1906.

<http://www3.stats.govt.nz/historic_publications/1906-census/1906-results-census/1906-results-census.html> [accessed 15 April 2014]
} 


\section{Wednesday, 27 November (Tarawera to Rangitaiki)}

The following day's journey began in much the same as the last, following the Napier-Taupo Road through more mountainous bush. After many miles, the road descended to the Waipunga Falls, where the Upper Waipunga and Waiuru Rivers converge and drop 600 feet in two distinct torrents. The party stopped for lunch on the banks of the waterfall, before continuing. By this stage they had left the Hawke's Bay district and the mountain ranges had given way to rolling hills. These hills in turn gave way to the Kaingaroa Plains, which in 1907 was a vast tract of pumice-sand deemed 'unfit for tillage or pasture' and covered only by tussock, hardy scrub and occasional mobs of wild horses. ${ }^{210}$ The party reached the Rangitaiki River and established camp on its banks, before visiting the small Rangitaiki settlement a short distance up the road. Rangitaiki was in fact little more than a coach-stop, a modest wooden accommodation house which also served as store and post office, in the vast expanse of pumice country.

\section{Thursday, 28 November (Rangitaiki to Kaingaroa)}

To lessen the distance they would have to travel next day, the party decided to leave the Napier-Taupo Road and take a shortcut north across the Kaingaroa Plains. Their intention was to follow an old, disused wool-waggon track as far as the Galatea region at the northeastern edge of the Kaingaroa:

The old wool track was very dim in places, and at times we were not sure whether we were on it or not. The vast sandy plain stretching before us was riddled with empty river beds, deep ditches where the river used to flow ... it was very difficult to get ourselves and our horses and traps down into, and then up out of these sandy ditches. Indeed our men people had sometimes to level off the top of the ridge

\footnotetext{
${ }^{210}$ The New Zealand Official Year-Book 1907: <http://www3.stats.govt.nz/New_Zealand_Official_Yearbooks/1907/NZOYB_1907.html> [accessed 15 April 2014]
} 
with a spade, which we had fortunately taken with us, before our horses could get the vehicles over. ${ }^{211}$

At midday they happened upon the Rangitaiki River again. Millie recalled that here they paused for lunch, and allowed the horses to drink, before:

we jogged again over that lumpy track, feeling like a little group of insects crawling along over that great wide flat circle of scrub-dotted earth ... Towards sunset time we began to look out for a suitable camping ground for ourselves and our tired horses. For this purpose water, of course, was the most important thing, and we looked first for that. But no sign on the river was to be found. We came to nothing but empty courses where once a river had run. As it began to grow dark we became very anxious, not for our own sakes, but for our horses, for it was very important that they should have water to drink after such a heavy day's work in the intense heat ... at last we were obliged to pitch our tents for the night, waterless, when it was too dark to see our way by the track any longer. Imagine our feelings, eating a dry meal, while our poor tired horses whinnied and pawed the ground asking for a drink. Dividing ourselves into four parties of twos we set off on foot that evening to the north, the south, the east and the west, hoping to strike the river. But none of us found any trace of it, and we lay down that night with a strong sense of anxiety. ${ }^{212}$

\section{Friday, 29 November (Kaingaroa to Galatea Station)}

The next day began with a similarly strenuous trek along an ever-fainter track:

We were up betimes the next morning, I can assure you, and after another "dry" meal we harnessed up our wandering horses and started

${ }^{211}$ M.A.P. 'No Water', New Zealand Herald, 21 March 1931, p. 4.

${ }^{212}$ M.A.P. 'No Water', New Zealand Herald, 21 March 1931, p. 4. 
off toward the Galatea mountains, which were now coming into sight ahead of us.

The track by this time had become almost indistinguishable - just a faint little trail of three lines where the wooden waggon wheels and the feet of the oxen had once trundled along taking loads of wool to Napier ... I shall never forget that long, hot, dreary day in the plains, our poor horses snuffing and snorting their disapproval at every step almost, while we ourselves endured a misery of thirst ... To add to our troubles now the track gradually faded away! There we were, homeless and helpless in the midst of that vast spreading plain. Then to our intense relief we noticed some little white tags of calico tied to some of the bushes. It was "the blazed trail," and we felt like a story book as we made our way from tag to tag. But would you believe it, after a while we were hampered by thousands of those lantern-shaped spider webs on the bushes, which we found rather difficult to distinguish from the tags of our 'blazed trail'. But somehow we made our way along until at last even the tags of the 'blazed trail' came to an end ... At that very moment two Maoris on horseback suddenly appeared over a ridge ahead of us ... Under instruction from the Maoris we were able to reach the river about three o'clock that day, and since we had not seen water since noon on the previous day it was a very welcome sight you may be sure. ${ }^{213}$

The river referred to was the Rangitaiki River, ${ }^{214}$ and the campers very soon arrived at Murupara. This was a staging-post on the road between Rotorua and Te Whaiti in $\mathrm{Te}$ Urewera. A store and post office stood on one side of the Rangitaiki River, while a fishing lodge took up the opposite bank. Although the lodge catered to Europeans, the community at Murupara was a Maori one, servicing the needs of the Ngati Manawa people spread around the district. The camping party called in at the lodge before continuing eastwards to the Galatea Station, a large sheep-run which had been farmed intensively since the 1880s: by 1907 the Station was a stark contrast with the dusty Kaingaroa, being lush pasture nestled at

\footnotetext{
${ }^{213}$ Ibid.

${ }^{214}$ Mansfield inaccurately called it the 'Galatea River' (1. 155).
} 
the base of the imposing, bush-clad Ikawhenua Mountain Ranges of the Western Urewera. At its southern end of the land that comprised the Station sat the homestead and sundry farm buildings. Beyond these, right at the base of the mountains, the party pitched their tent for the night.

\section{Saturday 30 November (Galatea to Te Whaiti)}

The next morning the camping party was permitted to visit the farm buildings and watch the sheep-shearers at work. Then, after leaving the station, they followed the main road southeast, plunging into the Urewera country. A 'winding path' ascended the hills, penetrating ever-deeper totara forest and bringing them 16 miles later to Te Whaiti. ${ }^{215}$ Te Whaiti (properly known as 'Te Whaiti-nui-a-Toi') straggled along a wide river valley carved by the Whirinaki River through the hills of the Western Urewera. In 1907 Te Whaiti was where the sealed road and telephone line into the Urewera ended. On the left bank of the Whirinaki River was the tiny store and post office, operated by the Mr Grant who was a police constable, sole representative of state government and 'everything else in authority and usefulness'. ${ }^{216}$ Also on the left-hand bank there were 'several native houses' with plots of 'grass, maize, and potatoes'. 217

On the right-hand bank but a mile further up the river on an elevated flat, stood the large Ngati Whare settlement with a 'native school' for the children, and a large meeting house. This Maori village was a main centre in 1907 , travellers noting that ' $[\mathrm{h}]$ ere the news from east, west, north, and south is exchanged, and in the wharepuni most afternoons you may hear a lively debate by excitable orators on the questions of the hour' ${ }^{218}$ Nearby were the remains of the 1840s mission station, and on a neighbouring peak were the blackened palisades of a once commanding pa. After conversing with Grant (George Ebbett recalled him saying that 'he had been there 12 years \& no white woman had passed his door'), ${ }^{219}$ the party forded the Whirinaki River with the help of the guide, Alfred Warbrick, whom they had encountered earlier on the journey into Te Whaiti. He led them to the Maori settlement and invited them to set up camp near the home of his brother Albert.

\footnotetext{
215 Paraki, 'The Urewera Country: A Prospecting Tour', New Zealand Herald, 12 June 1909, p. 1.

${ }^{216}$ C. A. Young, 'Autumn Ramblings', New Zealand Herald, 2 July 1904, p. 1.

${ }^{217}$ Special Reporter, 'Through the Urewera', Evening Post, 5 March 1904, p. 10

${ }^{218}$ C. A. Young, 'Autumn Ramblings', New Zealand Herald, 2 July 1904, p. 1.

${ }^{219}$ MS-Papers-7293-12.
} 


\section{Sunday, 1 December (Te Whaiti to inland Urewera)}

The party left Te Whaiti next day and headed further inland towards the Ruatahuna Valley, the traditional heartland of the Urewera. Millie Parker recalled that it was excessively hot: 'a blazing summer's day ... one of those fierce touches from Nature's lavish hand, when the earth sprawls breathless beneath the furnace of the sun'. ${ }^{220}$ They followed a rough 'horse vehicle track', ${ }^{221}$ which had been constructed as far as Ruatahuna in the face of opposition from local iwi, who viewed it as the thin end of the wedge as far as land alienation was concerned. ${ }^{222}$ The route into the Urewera is much the same today as it was in 1907: the road twists its way over the mountain ranges clothed in dense forest, rising hundreds of feet above deep ravines and plunging down into river gorges. Eventually the road scales the Tarapounamu peak: from this elevation, in every direction a sea of mountains dips and rises as far as the horizon. After a time, the road twists downwards to follow the course of a mountain creek. Another visitor to the Urewera in 1908 described the small settlements that appeared as the route neared Ruatahuna: 'here and there ... the seemingly interminable forest is varied by a little clearing' where 'roughly built thatched huts are dotted about'.223 Mansfield's description of pitching their tent near 'several whares' (11. 256-7) and an 'open clearing' (1.260), suggests the party established their camp on accessible land near a group of such roadside houses, rather than driving into the Ruatahuna Valley itself.

\section{Monday, 2 December (inland Urewera to Te Whaiti)}

The events of the following day are obscure. Mansfield's notebook entries at this point mention few place names, offer minimal narrative continuity and no other camper left a record of this section of the trip. Gordon suggested that rather than camping at a roadside clearing, they camped at Te Umuroa, a small kainga at the southernmost end of the Ruatahuna Valley. From there, he claimed 'Ebbett led the men in the party to the finely carved wharepuni (meeting-house) built in 1890 for the Tuhoe leader Te Kooti. On the return

\footnotetext{
${ }^{220}$ Margaret A. Parker, A Summer Day in 1907, p. 6, The New Zealand Herald, Saturday 4 April, 1931.

${ }^{221}$ MS-Papers-7293-12.

222 Judith Binney, Encircled Lands: Te Urewera, 1820-1921 (Wellington: Bridget Williams Books, 2009), pp. 353-382.

${ }^{223}$ James Cowan, New Zealand, or Ao-tea-roa (The Long Bright World): Its Wealth and Resources, Scenery, Travel-routes, Spas, and Sport (Wellington: John MacKay, Government Printer, 1908), p. 177.
} 
from what Gordon admits would have been an eight-mile walk, the men reported the distance was too great for the women, and so the whole party visited the 'great pah' at Ruatahuna, a mile and a half distant' (57). From here Gordon argued the campers returned to Te Whaiti where Mansfield found the 'Anglicized Maoris' (59) uninteresting.

This itinerary, while superficially neat, raises many questions. What Gordon meant by 'the 'great pah' at Ruatahuna' is rather uncertain: Ruatahuna was the name for the whole valley. The only 'great pah' was at Mataatua, the largest settlement located at the northern end of the valley, sometimes erroneously 'known as Ruatahuna'. ${ }^{224}$ Yet Mataatua was the site of Te Kooti's carved wharepuni which Gordon says the women never visited. Perhaps it is more plausible that after packing up their roadside camp, the party visited Te Umuroa, then did reach Mataatua that day; after all, Mansfield had written that she was 'on the way to Matatua' (1. 228) the day before. Mataatua was highly Europeanised: with its 'squares of cultivations, some of its houses shingled'225 and its residents often noted to be 'well-dressed in pakeha raiment', ${ }^{226}$ Mataatua may well have been the place where Mansfield found the inhabitants too westernised for her taste. In the end, only a skeletal itinerary can be inferred with any certainty from Mansfield's notes: in the morning, the campers visited Te Umuroa; Mansfield found the inhabitants of a second settlement distastefully 'westernised'; after lunch, the men went to a wharepuni in the afternoon but deemed the route too long for the women to attempt so the whole party visited a nearby 'great pah'. Then the campers had made the long journey back to Te Whaiti by the evening to sleep again beside the Warbrick's house that night.

\section{Tuesday, 3 December (Te Whaiti to Waiotapu)}

Descending from the Urewera bush, the party emerged once again onto the Kaingaroa Plateau. From Murupara they travelled westwards across the plains, following the dusty main road, 'practically straight for 21 miles'. ${ }^{227}$ The desolate terrain gave way eventually to the grassy rolling hills of the central geothermal district. This was in 1907, as it is today, an uncanny party of New Zealand, where steam leaks from the earth, boiling mud pools pulsate, and the smell of sulphur hangs in the air. That night's camp was near Waiotapu, a site of

\footnotetext{
${ }^{224}$ Special Reporter, 'Through the Urewera', Dominion, 15 March 1909, p. 6.

${ }^{225}$ Cowan, 177-8.

${ }^{226}$ C. A. Young, 'Autumn Ramblings', New Zealand Herald, 9 July 1904, p. 1.

227 'From Gisborne to Rotorua: Through the Uriwera Country', Poverty Bay Herald, 1 February 1906, p. 2.
} 
concentrated geothermal activity where the principal sites were still in Maori ownership. ${ }^{228}$ After pitching camp at the roadside, the party ventured by foot as far as the upper Waiotapu Stream, where there was to be found a 'large mud volcano standing about ten or twelve feet in height' up which visitors were permitted to climb by wooden steps. ${ }^{229}$ Further down the Waiotapu Valley was a multitude of colourful steaming lakes, sinter terraces, fumeroles, craters and cliffs composed of variously tinted rock and clay. It is unclear how many of these natural marvels the camping party visited before making their way back to the campsite for the night.

\section{Wednesday, 4 December (Waiotapu to Rotorua) - Saturday 7 December (Rotorua)}

The next day the party travelled north to Rotorua. By now they were well and truly on welltrodden tourist terrain. Two and a half miles before Rotorua they passed the village of Whakarewarewa, a popular destination for sightseers. A considerable portion of the area around Whakarewarewa was a Government Reserve and housed a European style hotel, but the principal attractions were the large geysers, silica terraces and hot pools that sat amongst the dwellings, pathways, washing lines and outhouses of a Ngati Tohourangi Settlement. Rotorua itself, home of the celebrated Sanatorium, was situated on the shores of Lake Rotorua, and was the 'only state-owned state-managed town in New Zealand', ${ }^{230}$ where 'every arrangement [was] made for the comfort and convenience of invalids or visitors'. ${ }^{231}$ Electric lights illuminated the wide streets by night. Hotels and bathhouses, the famous sanatorium and the Railway Station, shops, tennis lawns and 'pretty private gardens', were interspersed with 'well-behaved geysers' and hot pools, tamed and titivated for tourists' benefit. $^{232}$

The party spent the next few nights in Rotorua. After their arrival on Wednesday, the campers immersed themselves in the various hot pool complexes. On Thursday they took a tour, which was one of several inaugurated by the Government in $1903 .{ }^{233}$ It cost $17 \mathrm{~s} 6 \mathrm{~d}$ and

\footnotetext{
${ }^{228}$ The Cyclopedia of New Zealand: Industrial, Descriptive, Historical, Biographical Facts, Figures, Illustrations, 2, p. 814.

${ }^{229}$ Ibid.

${ }^{230}$ Cowan, p. 118.

${ }^{231}$ The Cyclopedia of New Zealand: Industrial, Descriptive, Historical, Biographical Facts, Figures, Illustrations, 2, p. 799.

${ }^{232}$ Cowan, p. 118.

${ }^{233}$ Don Stafford, The New Century in Rotorua: A History of Events from 1900 (Auckland; Rotorua: Ray Richards Publisher and Rotorua District Council, 1988), p. 49.
} 
covered 38 miles. Tourists were ferried across the Hamurana Spring in dinghies and offered refreshments at an accommodation house near the Okere Falls. They paid an additional fee to be escorted through Tikitere, a thermal region still in Maori ownership. ${ }^{234}$ The party also visited the sanatorium grounds, took a day trip to Whakarewarewa, visited friends and browsed the tourist shops. Elsie Webber also recalled:

My birthday fell whilst we were in Rotorua. During the afternoon we were looking in a shop window. I admired a small picture of 2 Maori children. K.B. went into the shop and purchased it. Later she gave it to me. On the back was written 'Birthday greetings from $\mathrm{K}$.

Mansfield'. ${ }^{235}$

\section{Sunday, 8 December (Rotorua to Atiamuri)}

On Sunday the party left Rotorua, and travelled southwards for 28 miles until reaching Atiamuri. This was a coach stop on the main road between Rotorua and Taupo and boasted only 'a diminutive hotel nestled under a terrace on the banks of the Waikato. ${ }^{236}$ The hotel stood within view of the towering peak of Pohaturoa, and within two miles of the Rainbow Falls. The party visited the falls that evening, following the roadway for a distance then scrambling off the road and down to the water's edge. Here, after a sweeping bend, the Waikato River fell 30 feet into a surging whirlpool where clouds of fine spray rose into the air, forming the 'beautiful rainbow effects' that gave the falls their name. ${ }^{237}$

\section{Monday, 9 December (Atiamuri to Wairakei)}

In her notes for the next stage of the journey, Mansfield recorded that she was 'on the road to Orakei - Koraka' (1. 524), which was another geothermal 'wonderland' on the banks of the Waikato River. However, some doubt is cast on the reliability of Mansfield's description of the itinerary for this section, since she labelled a later entry 'Orakei Korako' (1. 557) although her description is patently of Wairakei, a settlement significantly further south along Waikato

\footnotetext{
${ }^{234}$ Marama, 'Tourist Resorts of the Colony', Auckland Star, 16 January 1907, p. 9.

${ }^{235}$ MS-Papers-4010. This picture is still in the possession of Elsie Webber's granddaughter.

236 'Overland from Wellington to Auckland', Otago Witness, 14 August 1907, p. 87.

${ }^{237}$ The Cyclopedia of New Zealand: Industrial, Descriptive, Historical, Biographical Facts, Figures, Illustrations, 2, p. 820.
} 
River. ${ }^{238}$ Probably the party did not pursue the main road south, but followed instead a newly-constructed tourist route that skirted the curve of the Waikato River and took in Orakei Korako, although whether the party lingered there to see the sights is unclear - none of the extant accounts indicate that they did. The tourist road, 'hewn from the cliff-side three or four hundred feet sheer above the river', ${ }^{239}$ brought the travellers, after many miles, to the Aratiatia Rapids. These were over half a mile in extent and zig-zagged for 150 feet between overhanging fern-clad precipices. A pathway for sightseers led through the bush near the river's edge and afforded a bird's eye view of the torrents 'from four different parts of the road' ${ }^{240}$ It seems likely that the party camped in the vicinity of the rapids that evening.

\section{Tuesday, 10 December (Aratiatia to Taupo)}

From Aratiatia the party proceeded to Wairakei. In 1907 a large area of Wairakei was occupied by the Geyser House Hotel and its extensive grounds. The grounds, open to the public in the summer months, encompassed well-tended gardens, swimming baths, the Wairakei Stream and the Geyser Valley. This last was hailed as 'one of the most marvellous places in the thermal region' ${ }^{241}$ Here several geysers, brightly coloured silica terraces and hot pools glowed and shimmered amidst the garden foliage. After making a tour of the famed Geyser Valley in the morning, the party headed south towards Taupo. En route they stopped to view the Huka Falls. Here they found the Waikato River compressed between two narrow walls of rock, forming churning rapids for nearly half a mile. In 1907 a 'substantial suspension footbridge' spanned the falls at their narrowest point, ${ }^{242}$ enabling 'the tourist ... a grand view of the seething torrent' ${ }^{243}$ Ladders had been built constructed down the sides of the cliffs, allowing visitors to climb behind the thundering waterfall and gain 'the best idea of the magnitude of the fall'. ${ }^{244}$

Three miles further down the main road from the Huka Falls, the party arrived at the European township of Taupo on the shores of Lake Taupo. In comparison with Rotorua, Taupo was an unpretentious tourist resort: it was supplied with 'two hotels ... a couple of

\footnotetext{
${ }^{238}$ See also $1.557 \mathrm{n}$.

${ }^{239}$ Cowan, p. 139.

${ }^{240}$ The Cyclopedia of New Zealand: Industrial, Descriptive, Historical, Biographical Facts, Figures, Illustrations, 2, p. 815.

${ }^{241}$ Ibid.

${ }^{242}$ Marama, 'The Tourist Resorts of the Colony', Auckland Star, 2 January 1907, p. 9.

${ }^{243}$ The Cyclopedia of New Zealand: Industrial, Descriptive, Historical, Biographical Facts, Figures, Illustrations, 2, p. 816.

${ }^{244}$ Marama, 'The Tourist Resorts of the Colony', Auckland Star, 2 January 1907, p. 9.
} 
stores and a post and telegraph office. ${ }^{245}$ The campers continued through the township for another two miles to The Terraces, a spa-hotel at the Onekeneke Hot Springs. The hotel, a plain two-storey building, stood 'in the midst of a grove of English trees' and 'well-kept gardens', where the party was permitted to erect the tent. ${ }^{246}$ A short walk from the hotel were a host of 'miniature hot lakes, mud geysers, boiling pools, silica terraces', as well as the wooden bathhouses erected over 'a natural soda spring and sulphur and alum baths', which the party visited that night and the following morning. ${ }^{247}$

\section{Wednesday, 11 December (Taupo to Runanga)}

The campers departed next morning by the Napier-Taupo Road and travelled westwards across the undulating pumice plains. They passed Opepe, a small circle of graves in a small circle of fir trees, ${ }^{248}$ but otherwise there was little to relieve the eye until they reached Rangitaiki at noon. From this point on they were retracing the same route they had taken on their outward journey, but instead of travelling as far as Tarawera, they stopped in the Runanga Valley. This was an isolated spot at the beginning of the mountain ranges, with nothing but a small roadman's cottage. The house, fronted by a vegetable garden, closed in by timber rails to keep wild pigs out, stood opposite two large grazing paddocks. In these paddocks, between the main road and the Waiarua Stream, the party pitched their tent.

\section{Thursday, 12 December (Runanga to ?Te Pohue); Friday, 13 December (?Te Pohue to Eskdale);}

There is no extant account of the next three days. The party retraced their outward journey along the Napier-Taupo Road, possibly covering the distance between Runanga and Te Pohue in one day. If Mansfield's reference to 'willows lashing together' (1. 701) at the final camping site is trustworthy, the party reached the willow-fringed Esk River by 13 December, and again camped on Ebbett's land as they had done three weeks earlier.

\footnotetext{
${ }^{245}$ Ibid.

${ }^{246}$ Marama, 'The Tourist Resorts of the Colony', Auckland Star, 1 December 1906, p. 9.

247 Ibid.

248 See 11. 667-8n.
} 


\section{Saturday, 14 December (Eskdale to Hastings), Sunday, 15 December (Hastings); Monday, 16 December (Hastings)}

From this point, the camping holiday had essentially ended. A 1946 account written by Mrs G.G. Robieson (EKB), with whom Mansfield had an intense friendship in Wellington in 1907, indicated that Mansfield spent several nights in Hastings (presumably with the Ebbetts) before returning to Wellington. While in Hastings, so the account suggests, she paid a visit to EKB who was holidaying in nearby Napier (Gordon, 89-90). ${ }^{249}$

\section{Tuesday, 17 December (On the train back to Wellington)}

The two girls caught the train home on 17 December. Once again, this would have been a day-long trip, following the same route and offering the same countryside views that they encountered on the outward journey. Probably they left Hastings by the 9:15 am train; not until 5.10 pm would they have arrived back in Wellington. ${ }^{250}$

\footnotetext{
${ }^{249}$ The same account stated that, while in Napier, Mansfield entertained EKB with 'excellent mimicries' of her travelling companions and of fat old Maori women' (Gordon, 89-90). Gordon found this account amongst the assemblage of Mansfield-related papers retained by G.N. Morris, of Auckland. This private collection was subsequently acquired by the Turnbull Library, and I have searched Turnbull's holdings of G.N. Morris papers exhaustively - no such account by EKB now exists. Possibly it was lost or destroyed in the intervening decades, however there is now no way of assessing how reliable EKB's recollection was.

${ }^{250}$ Hawke's Bay Almanac, p. 181.
} 


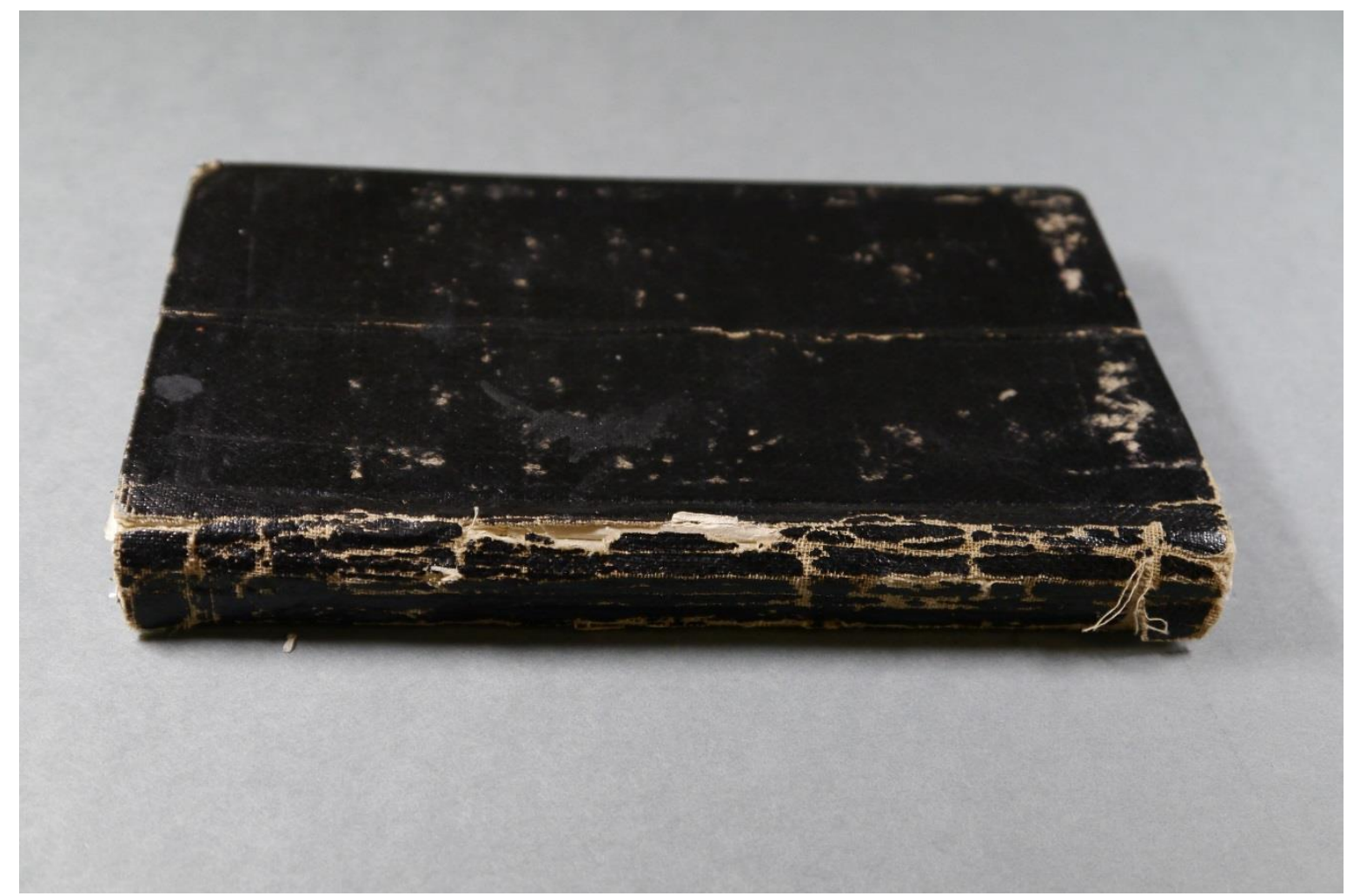

Image 1: The Urewera Notebook

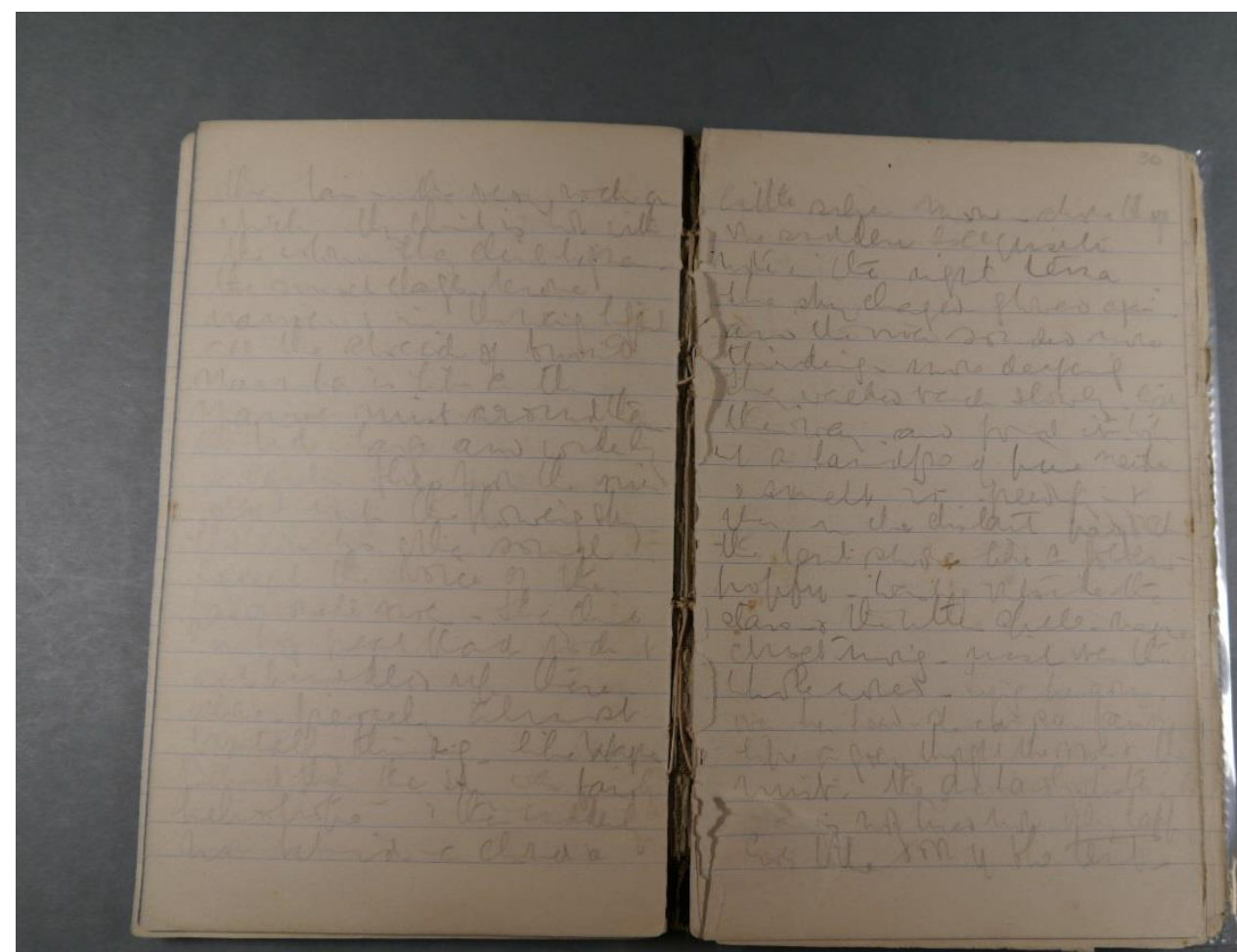

Image 2: Internal pages of the Urewera Notebook, with torn stubs along the binding and folios hanging loose 


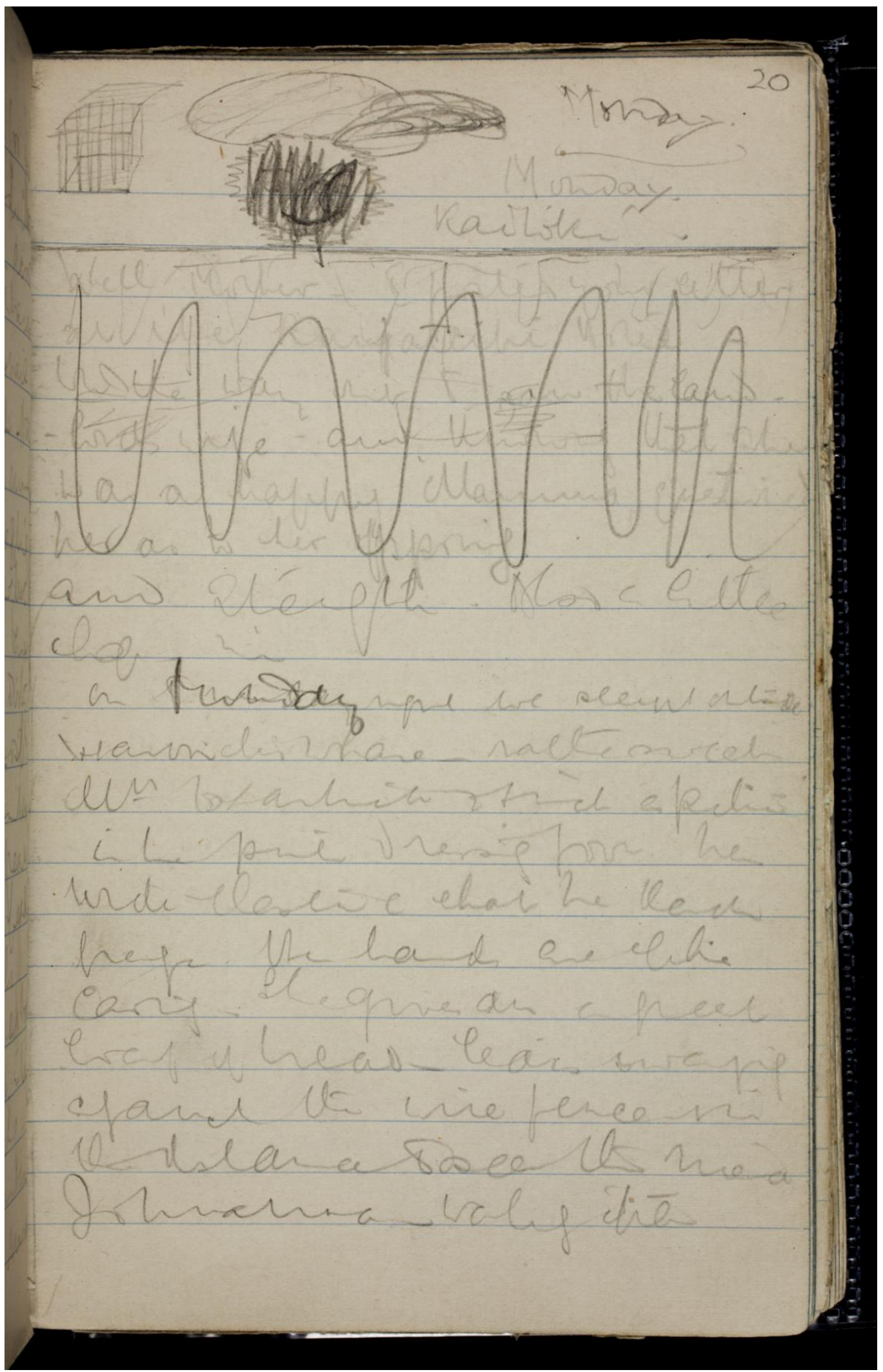

Image 3: Folio 20 of the Urewera Notebook. This single page contains at least four separate entries: the draft letter occupying lines 3-8 (transcription 11. 287-9), an earlier entry that had filled folio 19 is concluded on lines 9-10 (transcription 11. 303-4), a description of the Warbrick family takes up lines 11-21 (transcription 11. 305-10). A doodle and headings 'Monday' and 'Kaitoki' are inserted in lines 1-2 (transcription 11. $287 n)$. 
ra

en shotera citat geh qu Wha gre pátip.

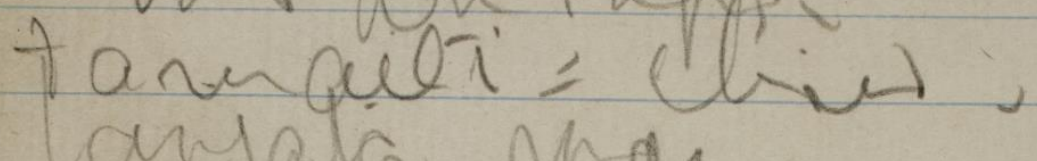
congata nhan

Pramait

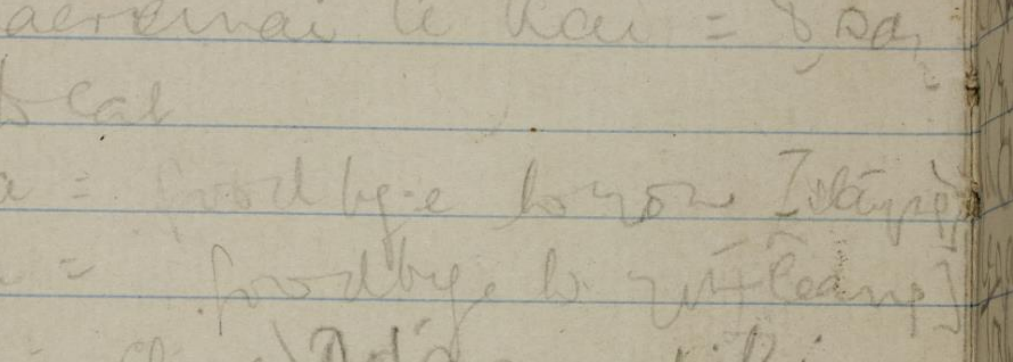

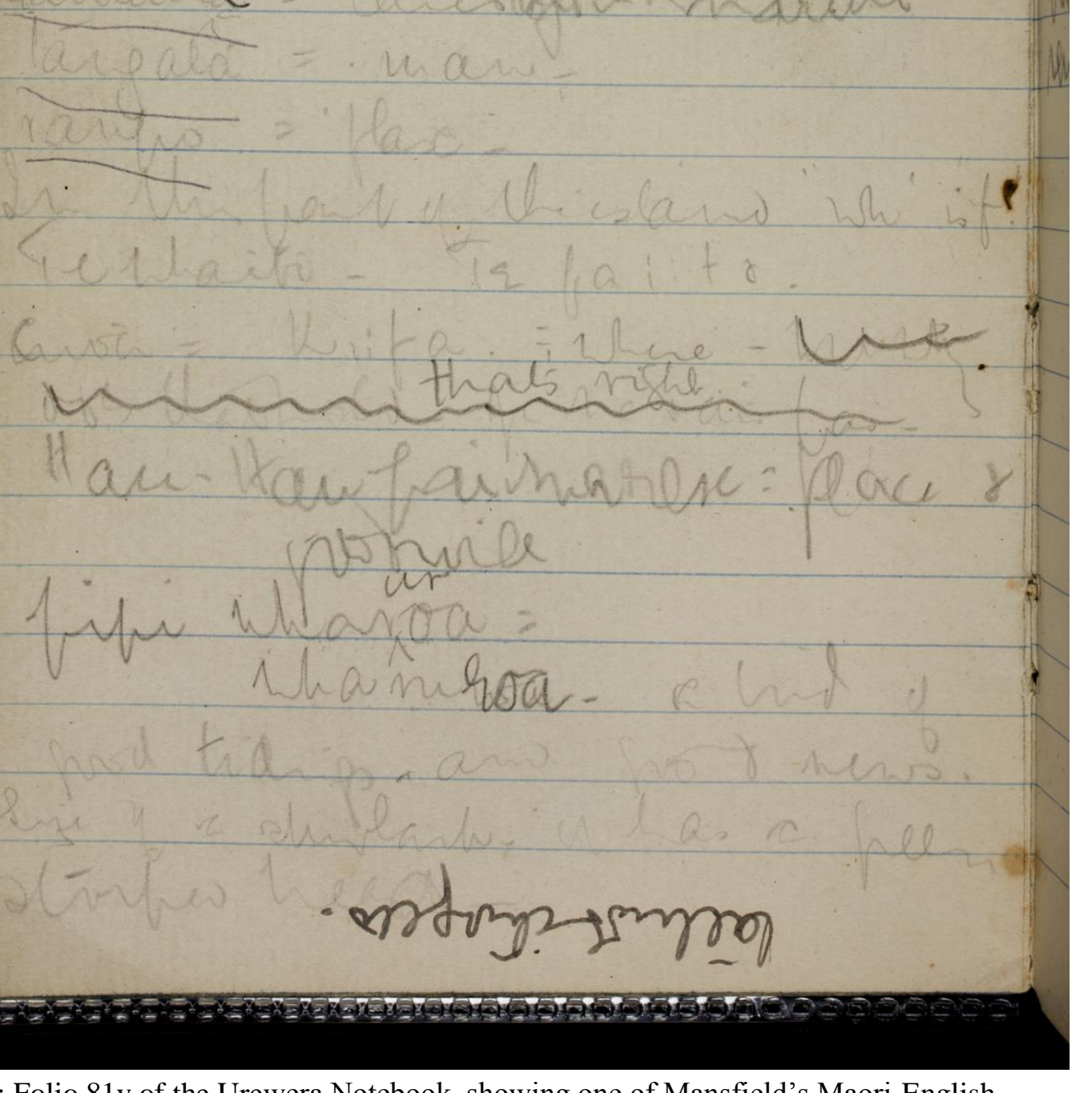

Image 4: Folio 81v of the Urewera Notebook, showing one of Mansfield's Maori-English translation lists 


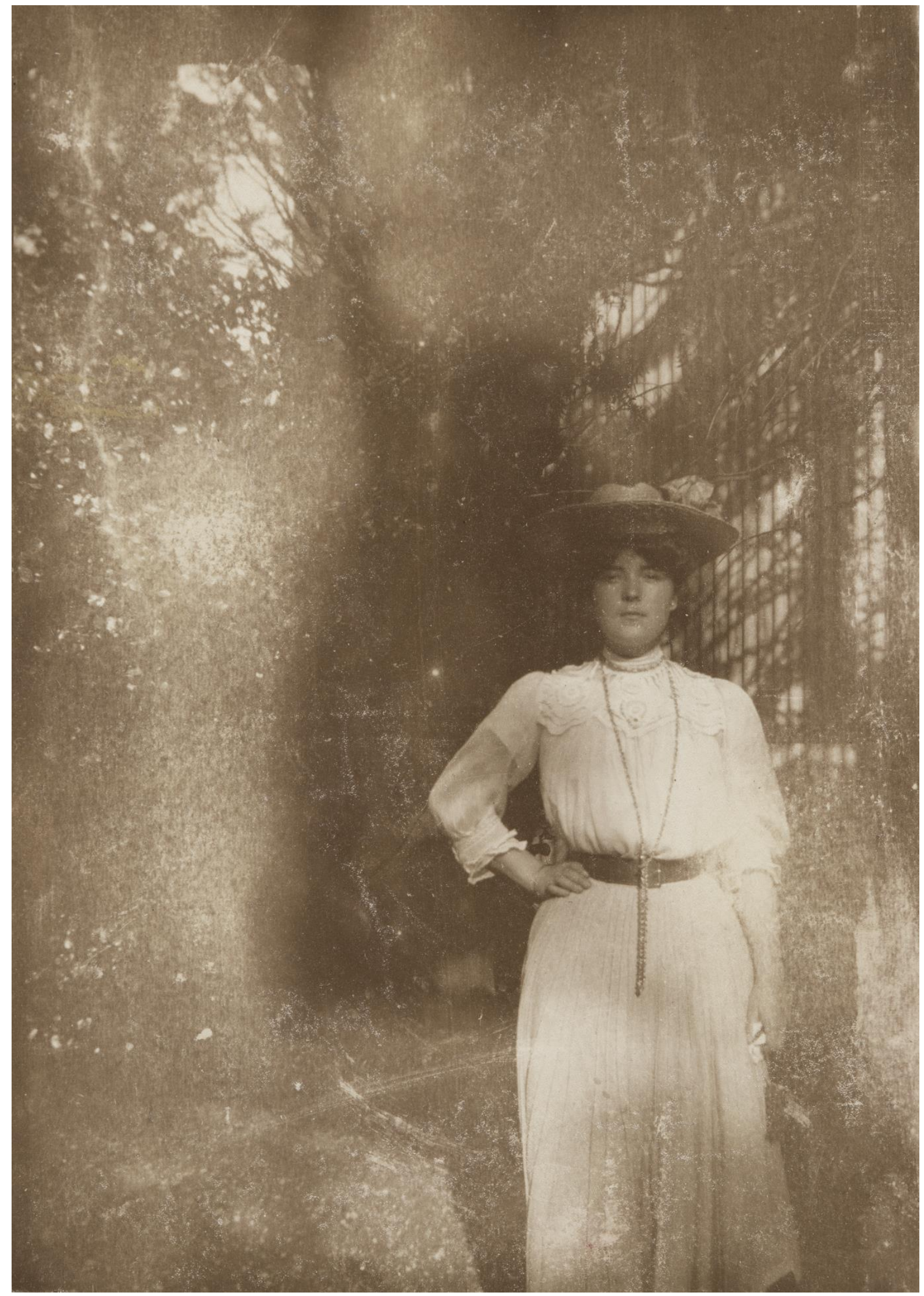

Image 5: Katherine Mansfield in the garden of 47 Fitzherbert Terrace, 1907 


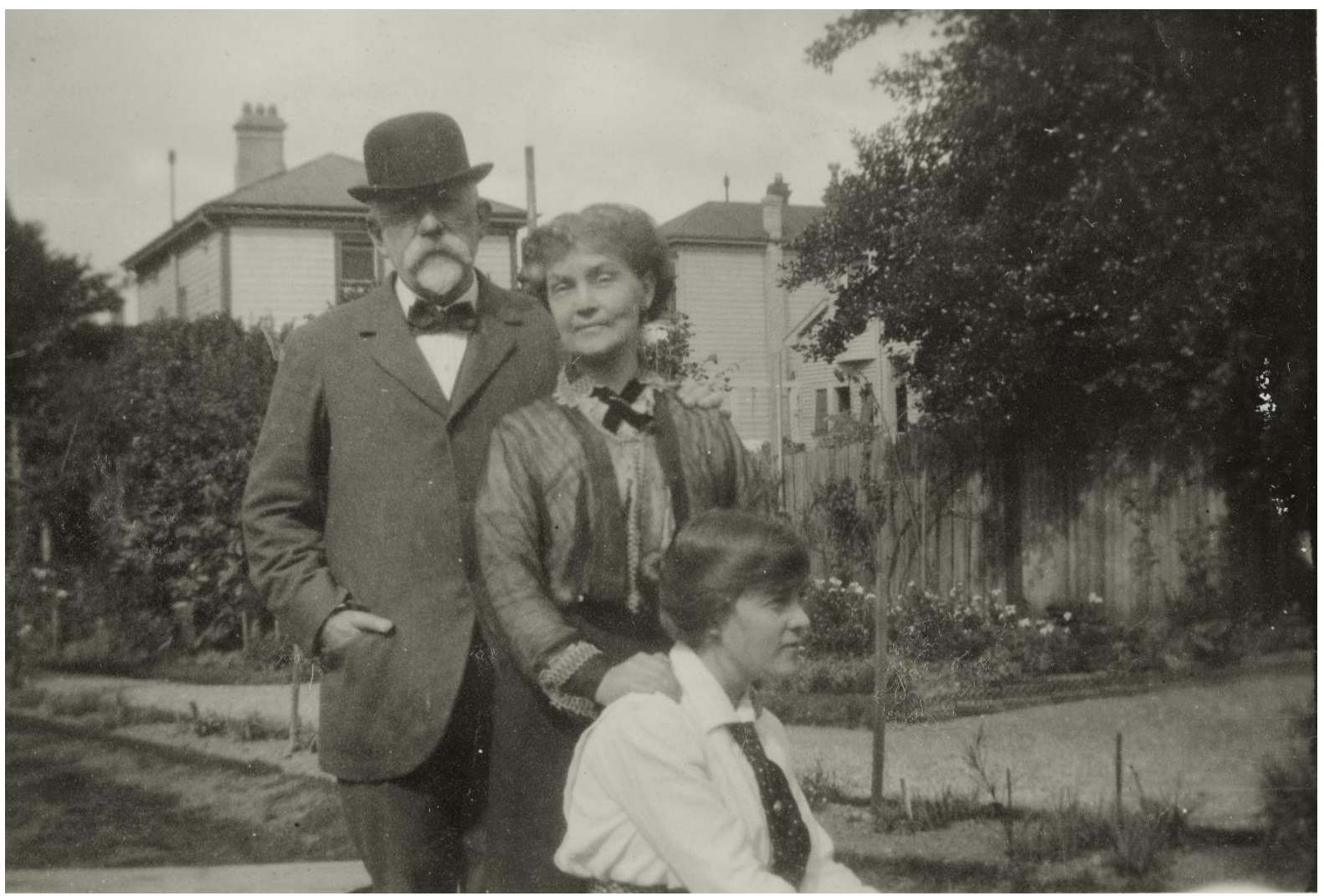

Image 6: Harold, Annie and Jeanne Beauchamp at 47 Fitzherbert Terrace, 1907

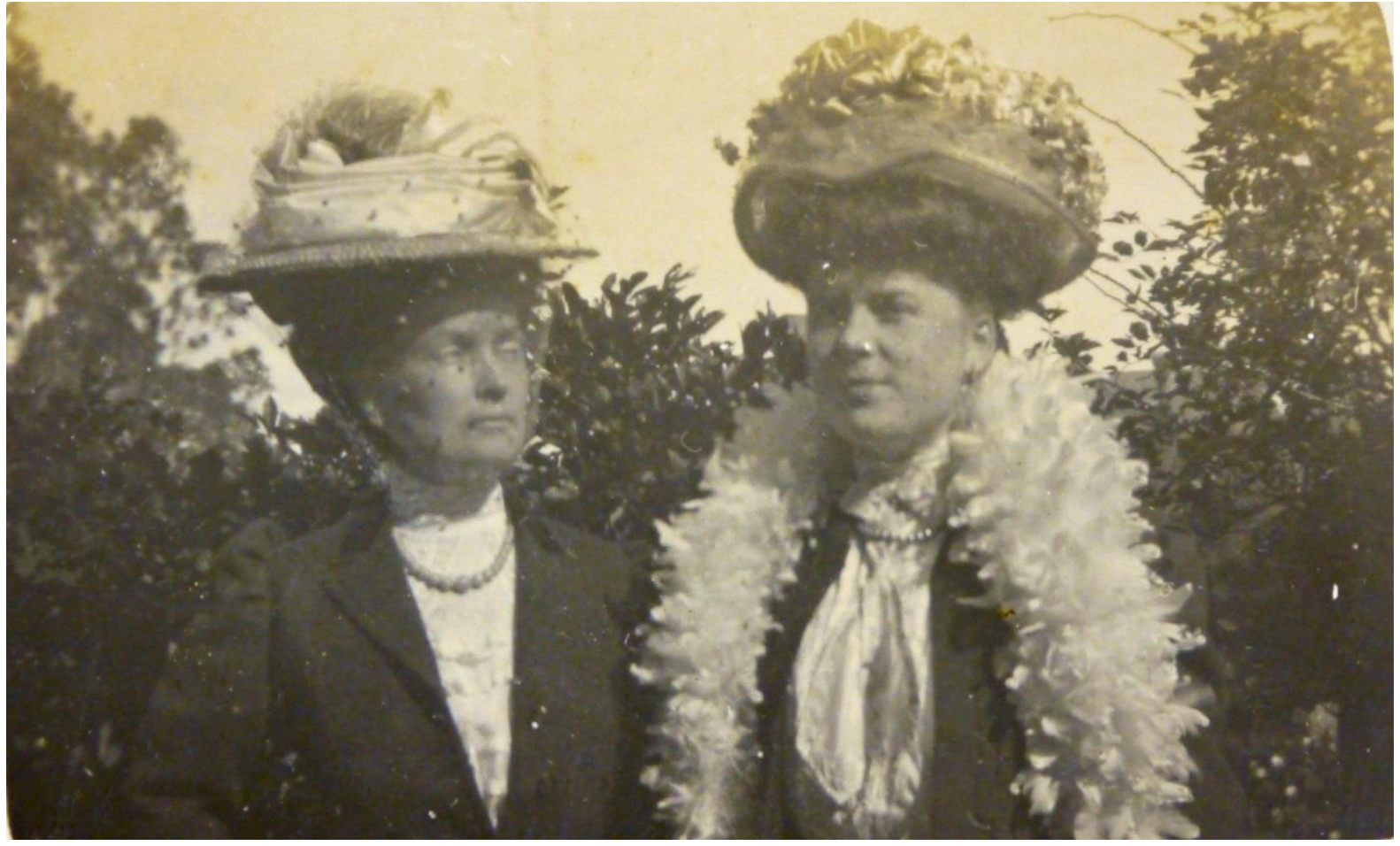

Image 7: Annie and Charlotte 'Chaddie' Beauchamp at 47 Fitzherbert Terrace, 1907 


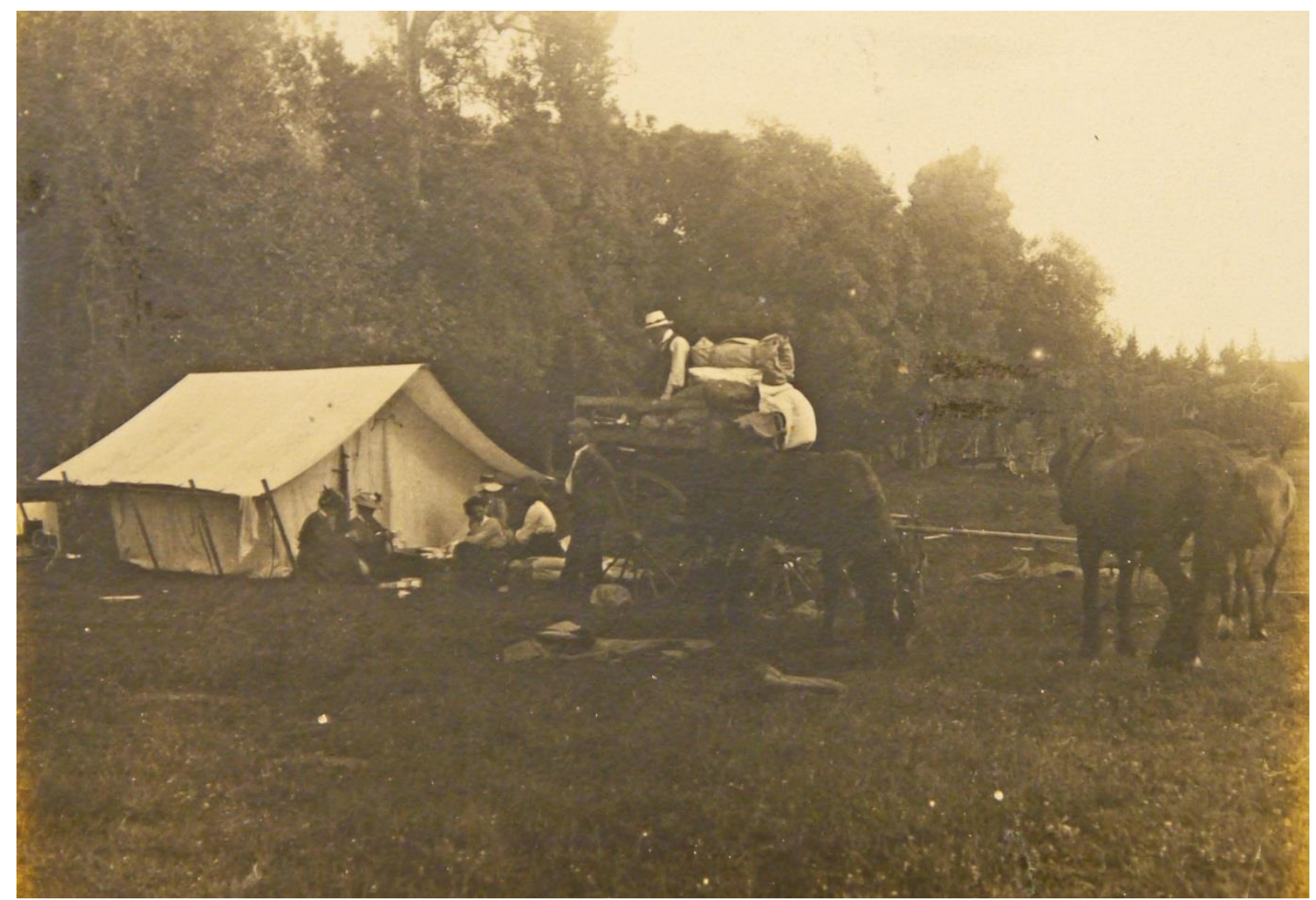

Image 8: The camping party at Eskdale. From left to right: Annie Leithead, Millie Parker, Maud Ebbett, Elsie Webber, Katherine Mansfield (seated, looking away from the camera and wearing a white blouse and black skirt), Mr Hill, George Ebbett on the luggage waggon.

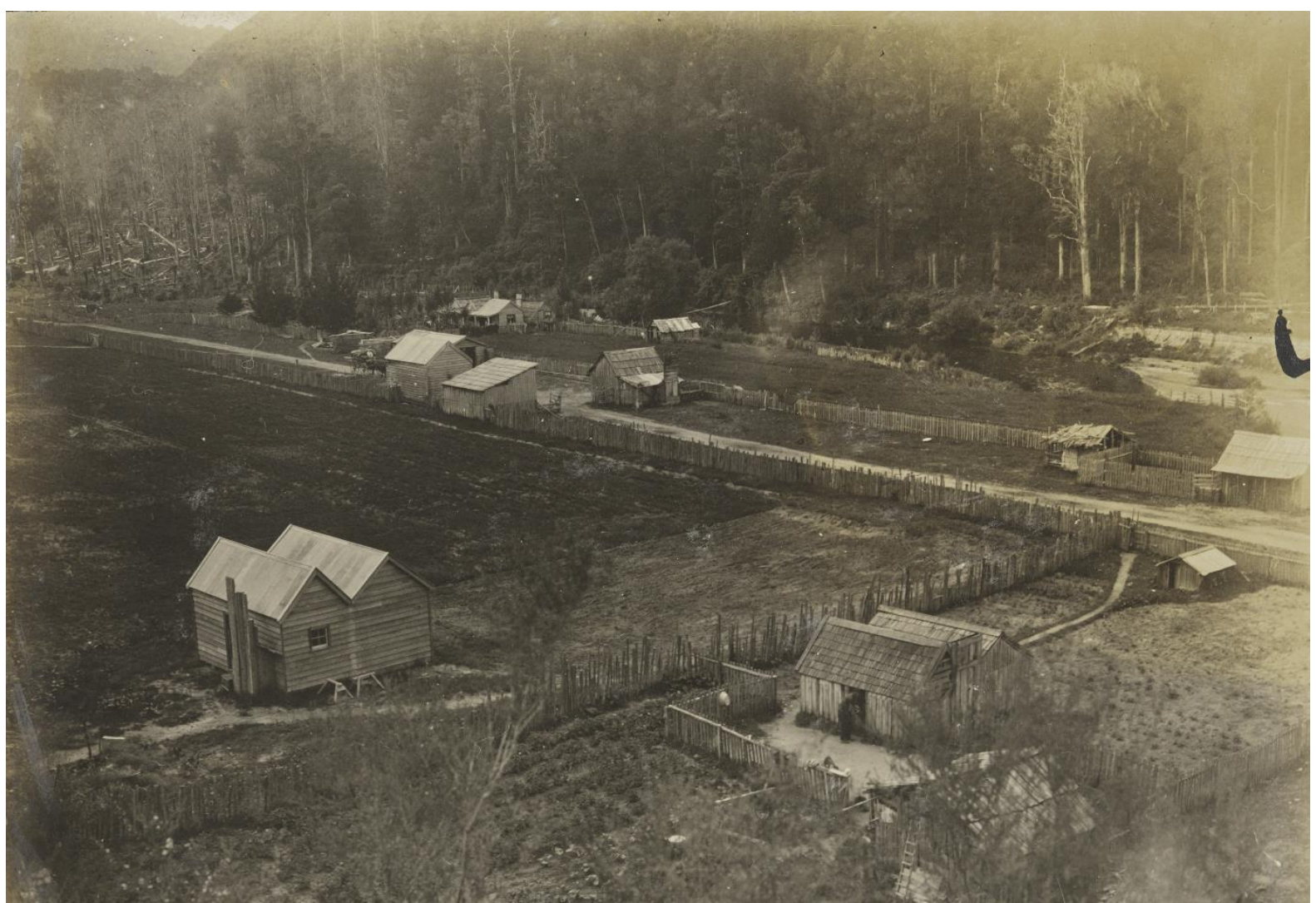

Image 9: Te Pohue, or 'Bodleytown', with evidence of bush burnings in the background 


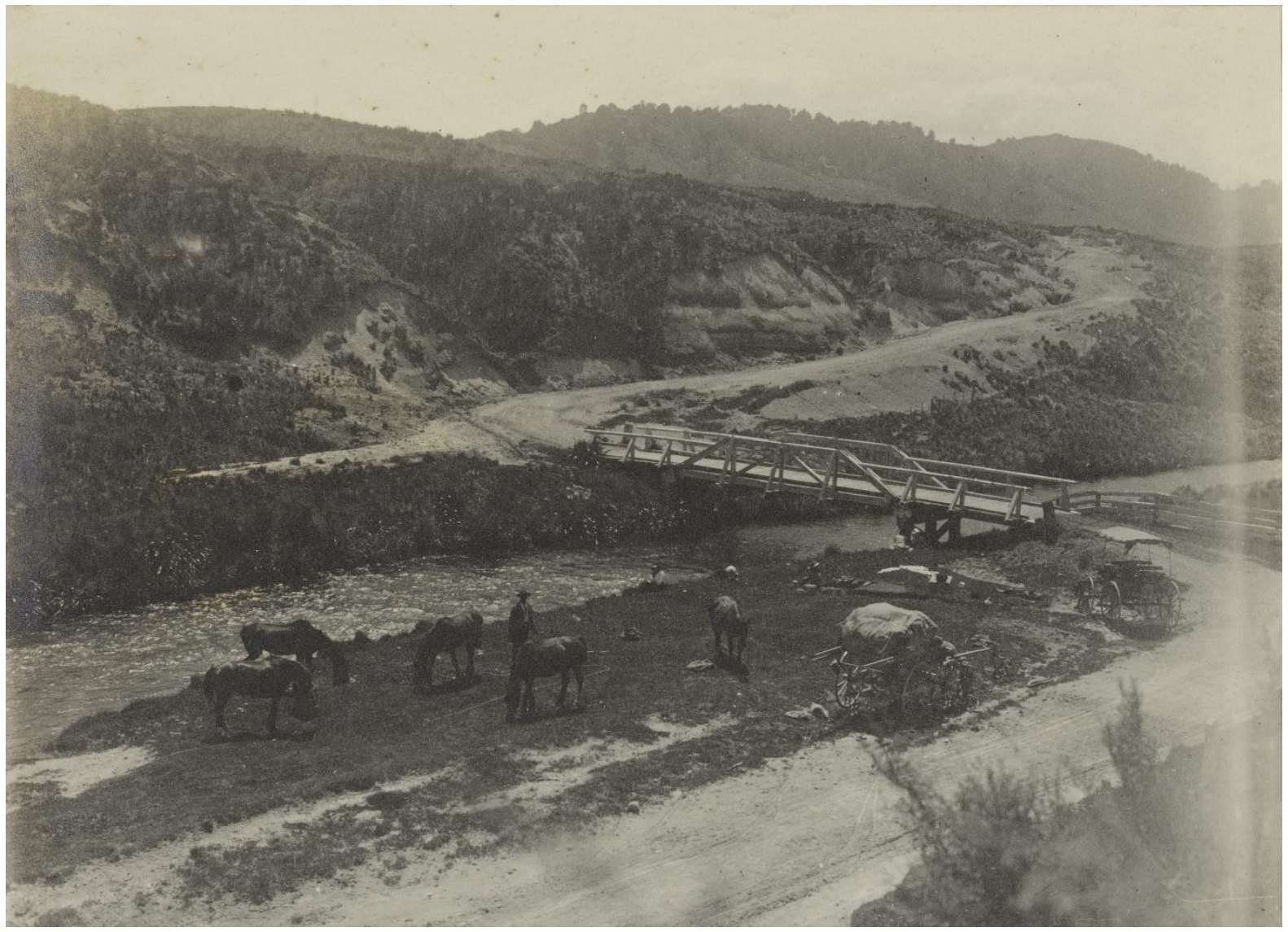

Image 10: Allowing the horses to graze along the Napier-Taupo Road

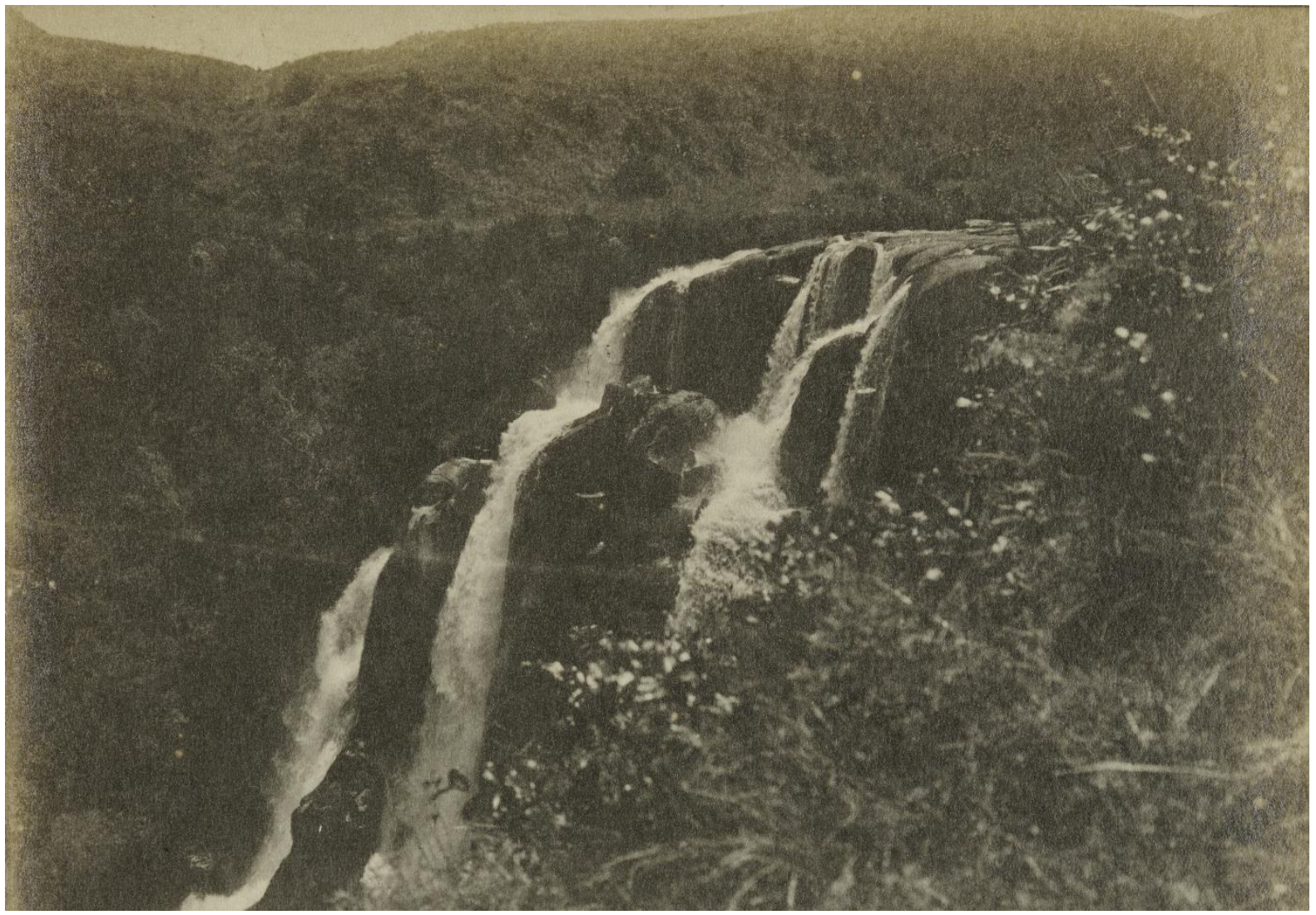

Image 11: The Waipunga Falls, along the Napier-Taupo Road 


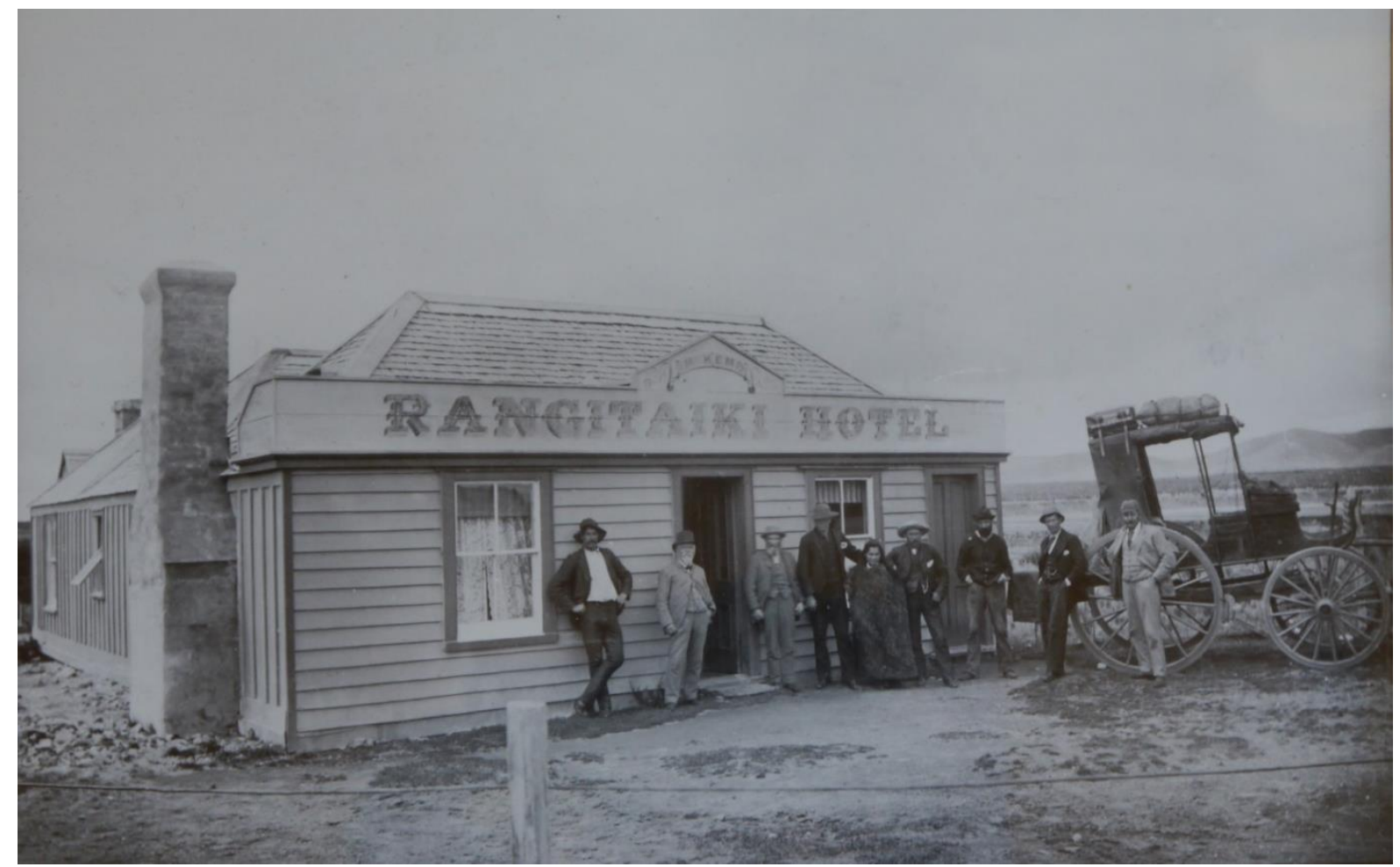

Image 12: The Rangitaiki store and accommodation house, 1907

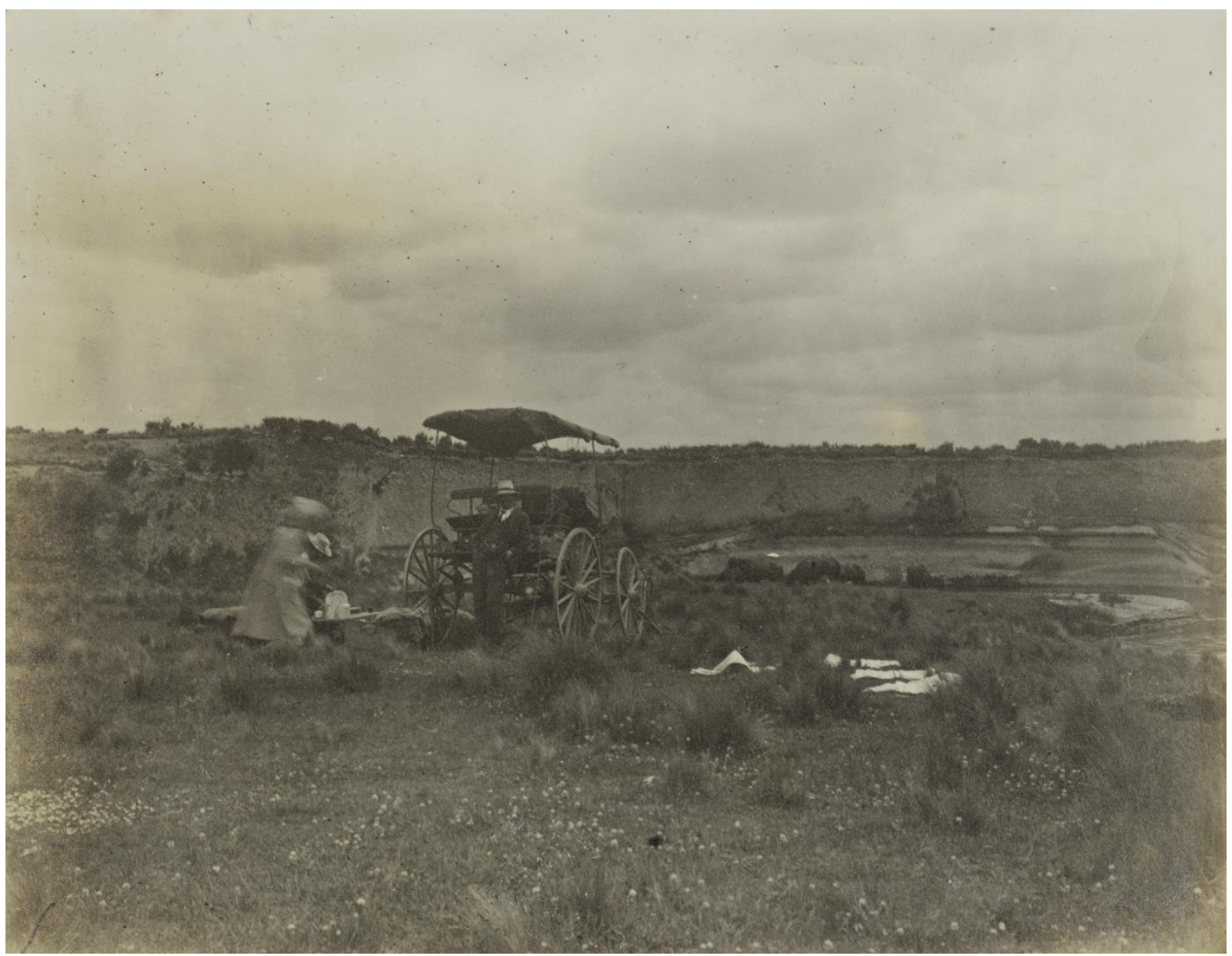

Image 13: The campers on the Kaingaroa Plains 


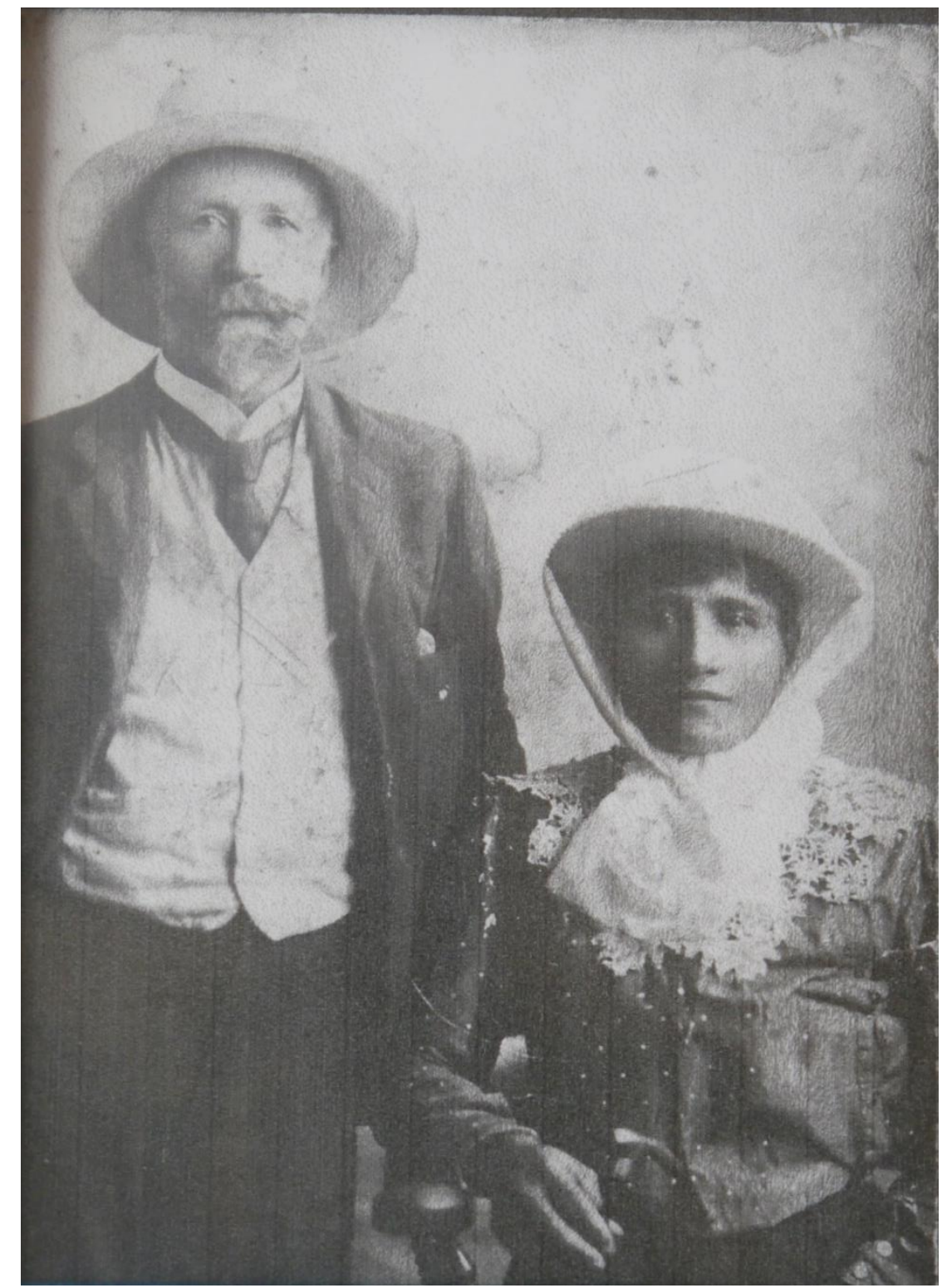

Image 14: William Henry Bird and his wife Kiekie Hopaia, whose accommodation house Mansfield visited at Murupara 


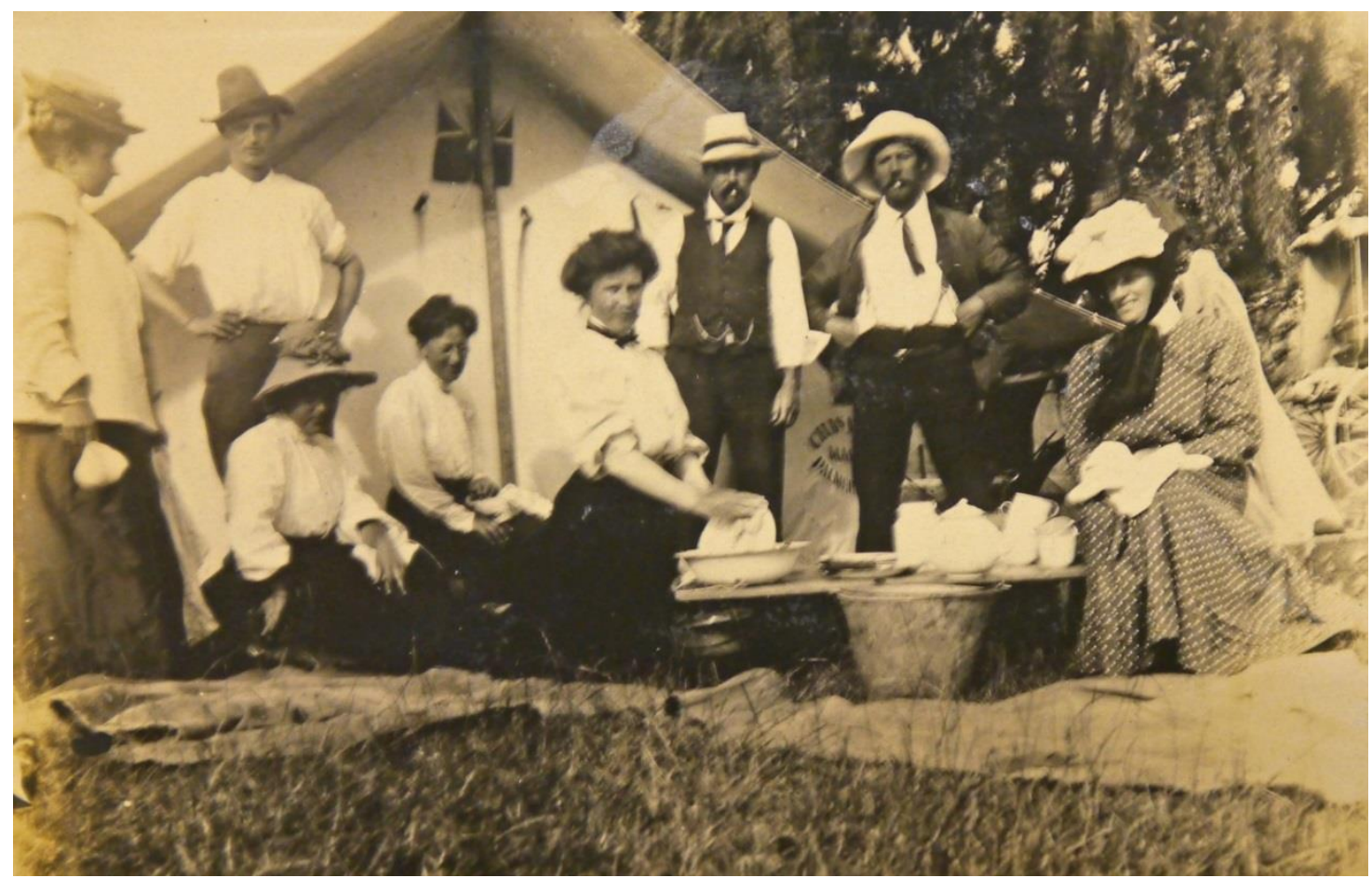

Image 15: The campers at the Galatea Station. From left to right: Annie Leithead, Mr Hill, Katherine Mansfield, Maud Ebbett, Elsie Webber, George Ebbett, Herbert James Webber, Millie Parker

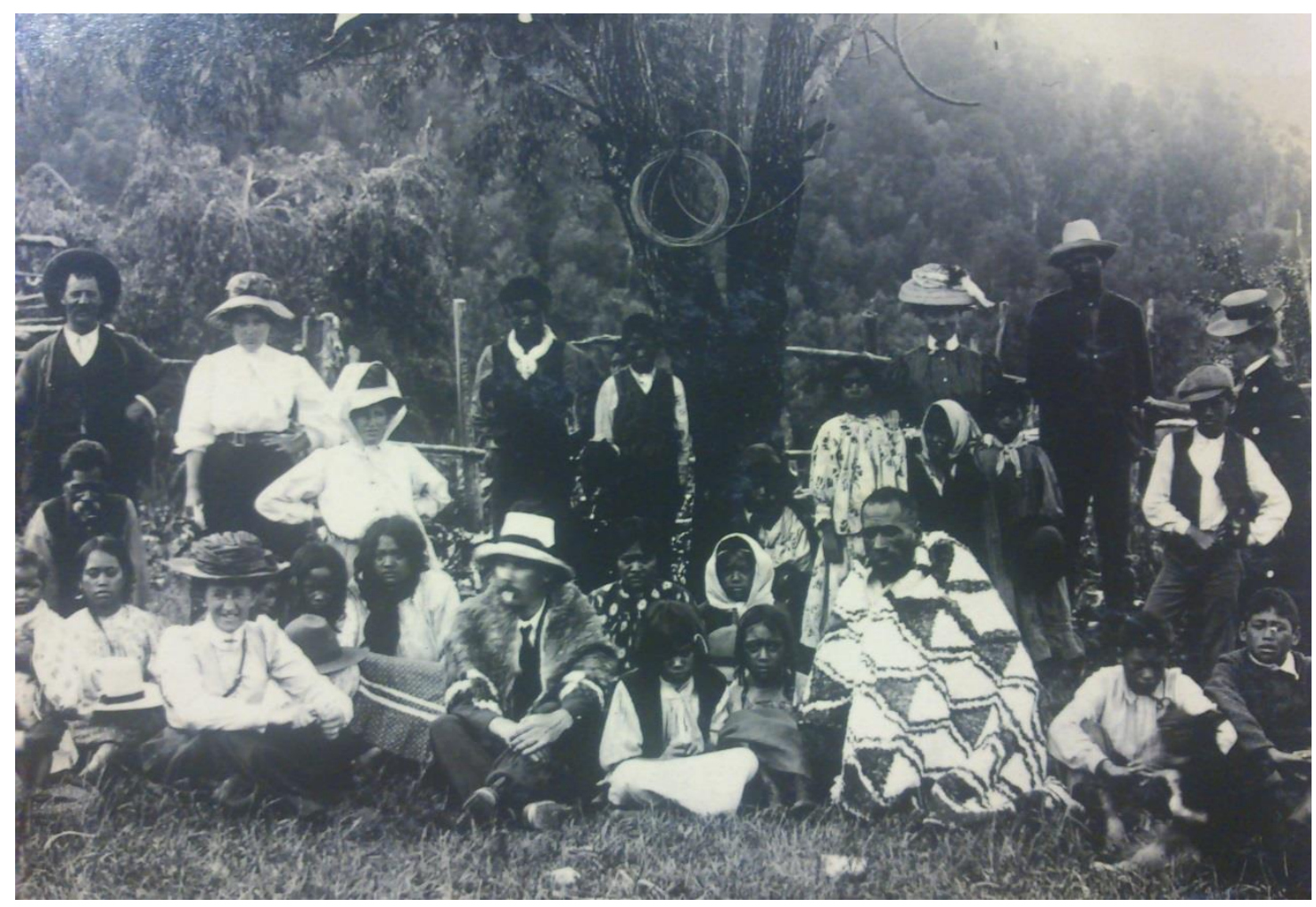

Image 16: The camping party with local residents at Te Whaiti. From left to right: Herbert James Webber, Katherine Mansfield, Maud Ebbett (seated), Elsie Webber (kneeling), George Ebbett (seated), Millie Parker, Annie Leithead. Between Millie Parker and Annie Leithead stands Alfred Warbrick. 


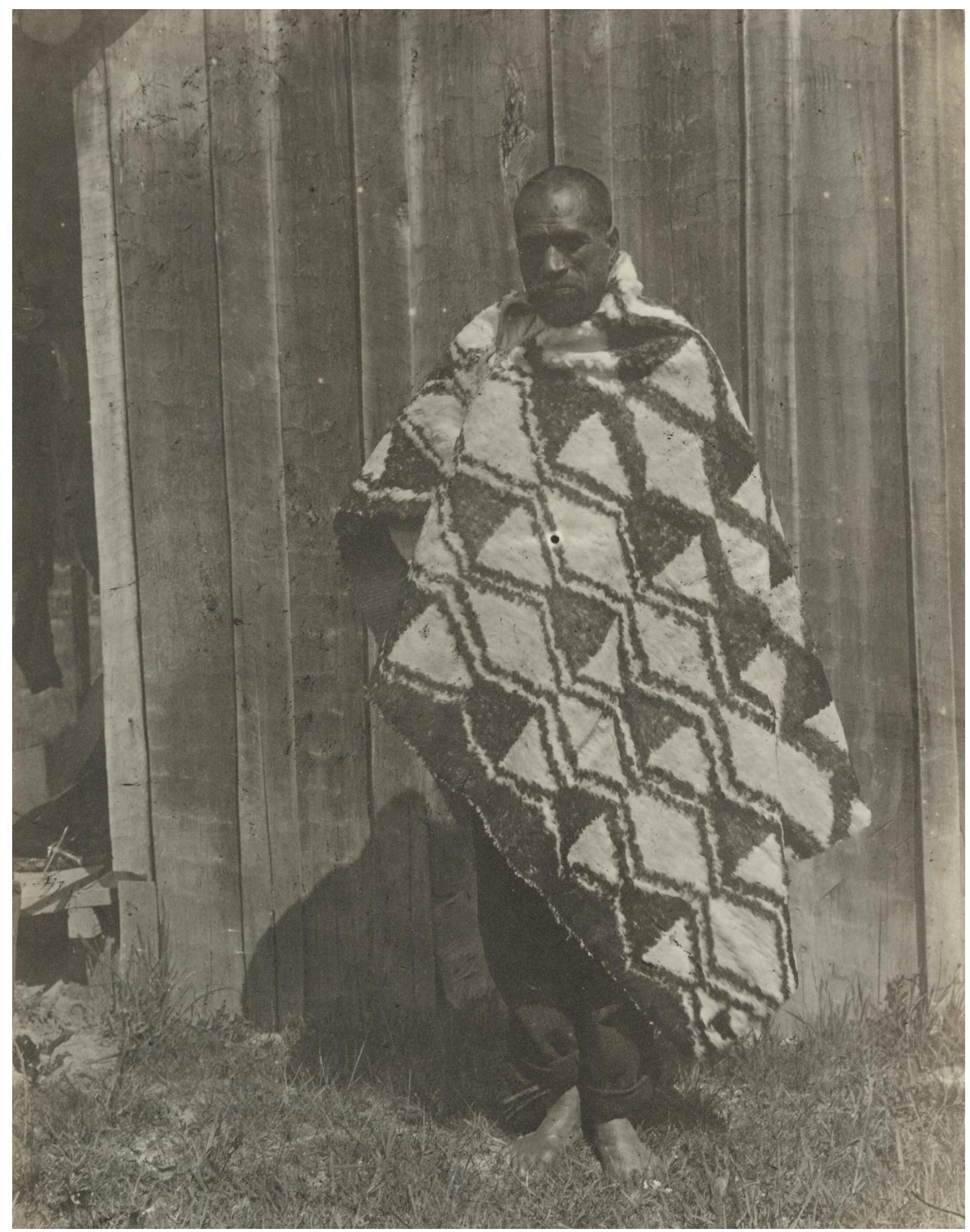

Image 17: Unidentified man at Te Whaiti, 1907. This image is included in Katherine Mansfield's photograph album containing pictures of her camping trip. Kaumatua from Murupara suggest that he may have been the Ngati Whare chief, Whatanui. 


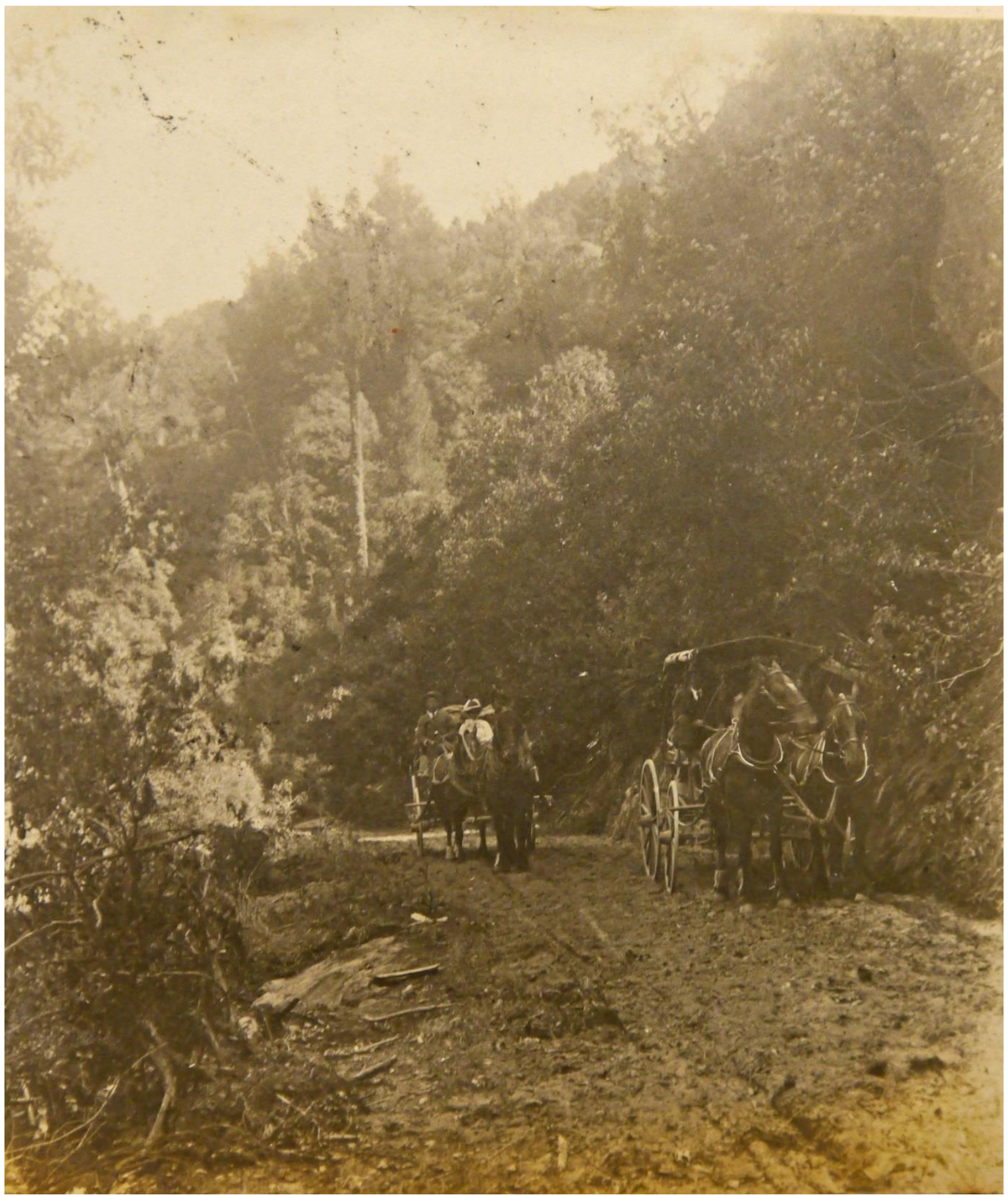

Image 18: The camping party returning from Ruatahuna to Te Whaiti 




Image 19: The camping party stopping for lunch, possibly in the Urewera. The individual members of the camping party have not been identified, although the man seated in the centre and looking at the camera is probably Herbert James Webber. 


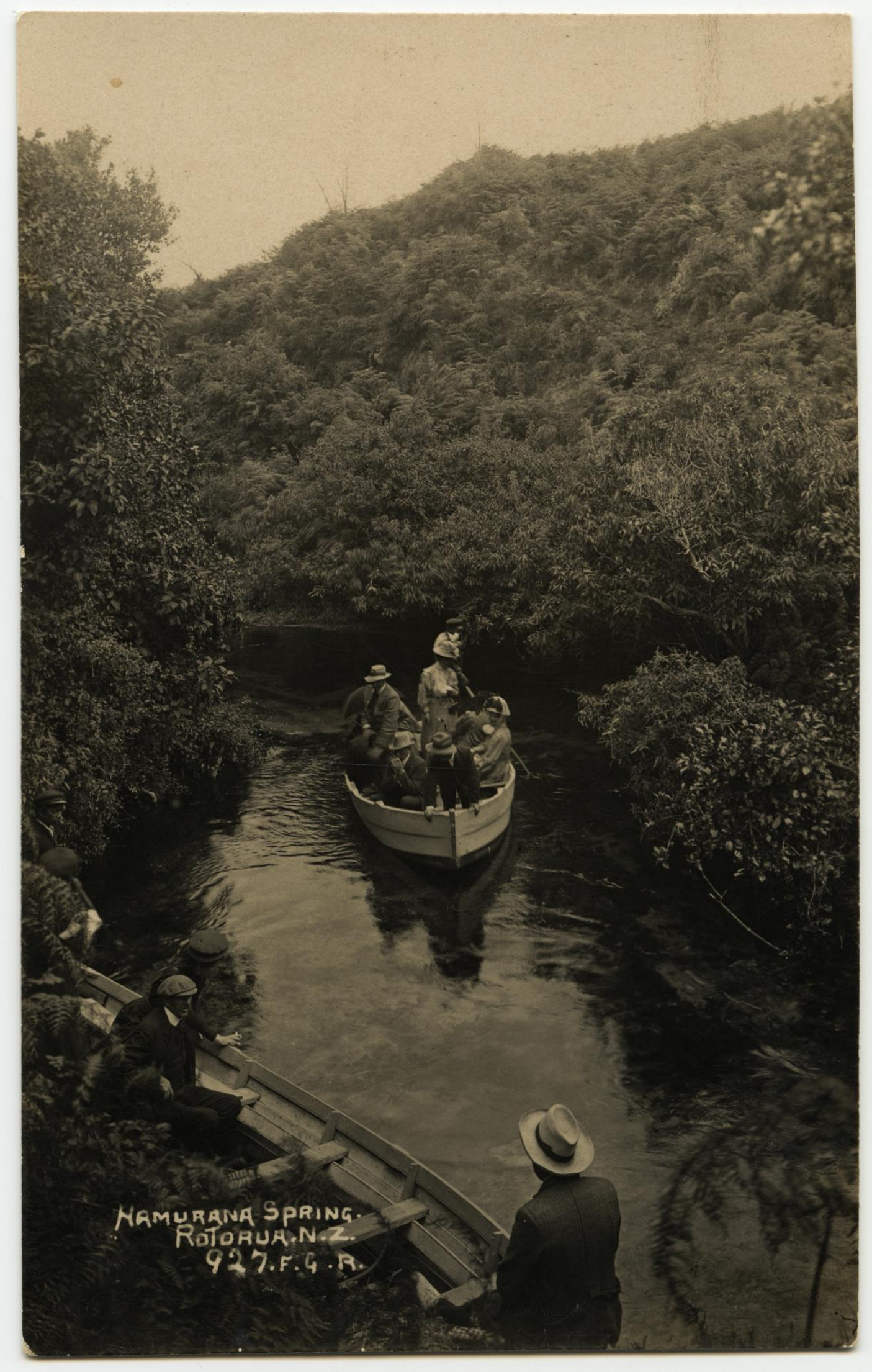

Image 20: A photograph belonging to George Ebbett, taken at the Hamurana Spring near Rotorua, during the 'Round Trip' 


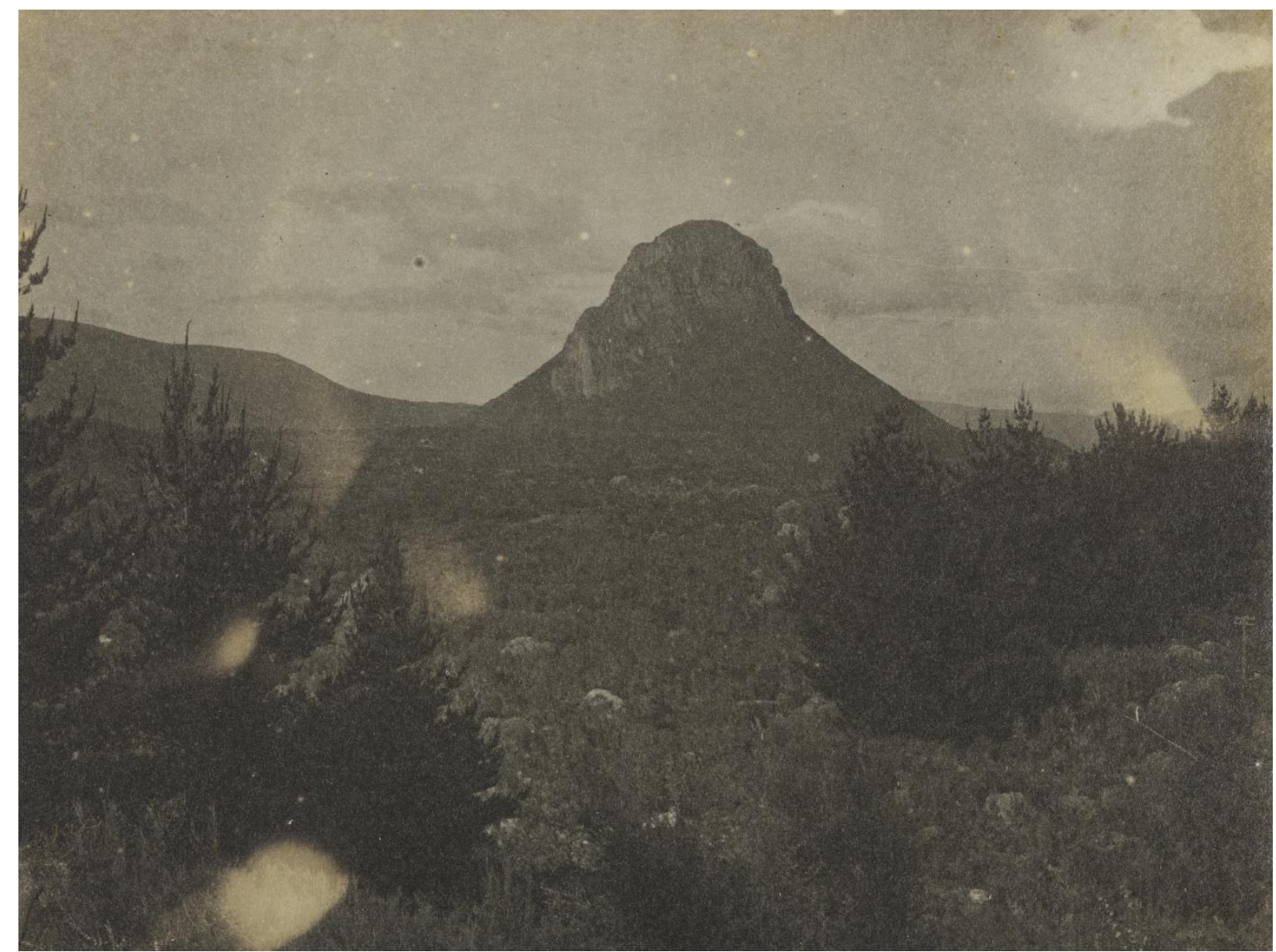

Image 21: The mountain Pohaturoa, on the banks of the Waikato River

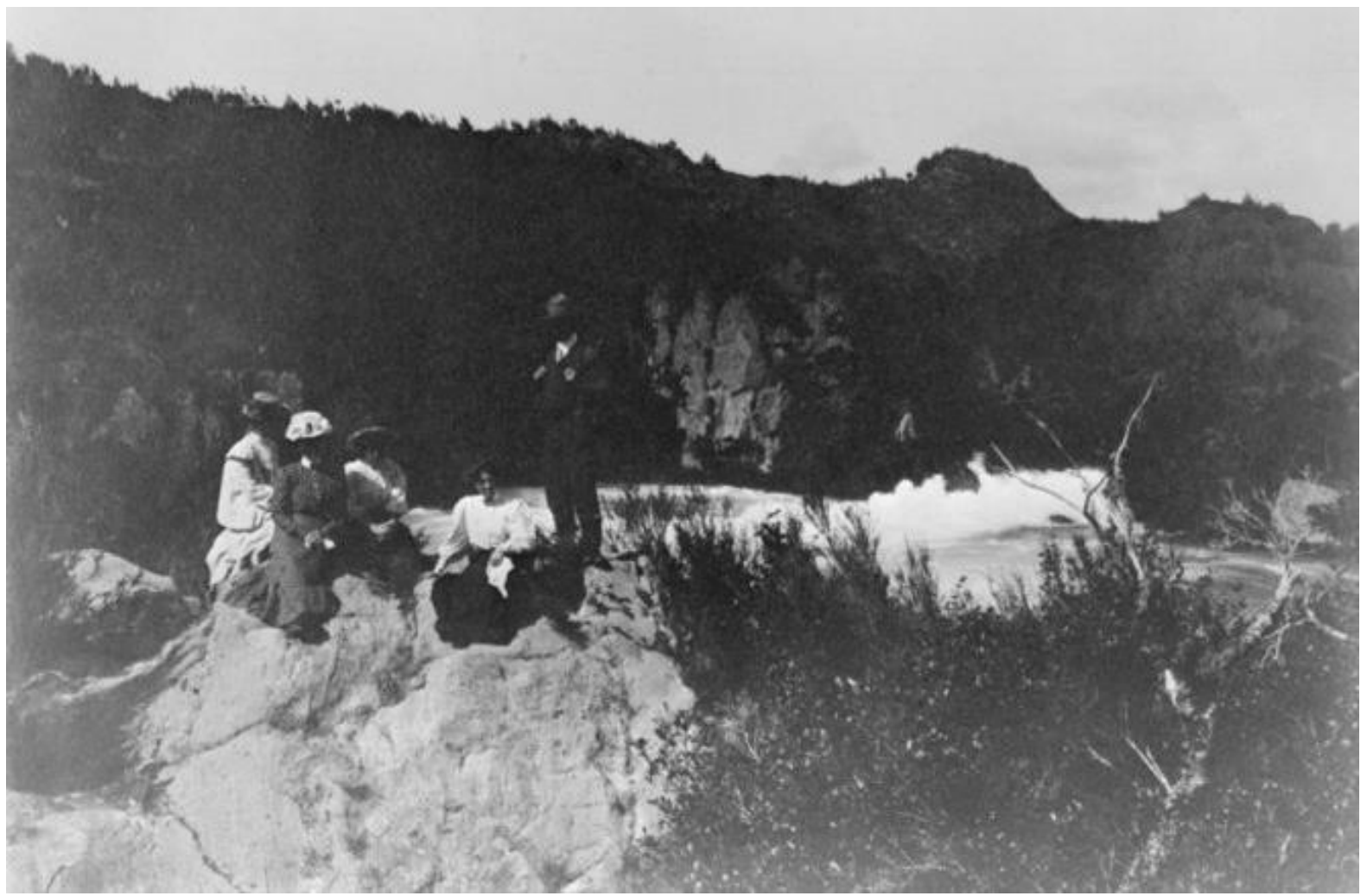

Image 22: The camping party at the Aratiatia Rapids. From left to right: Annie Leithead, Millie Parker, Elsie Webber, Herbert James Webber. 


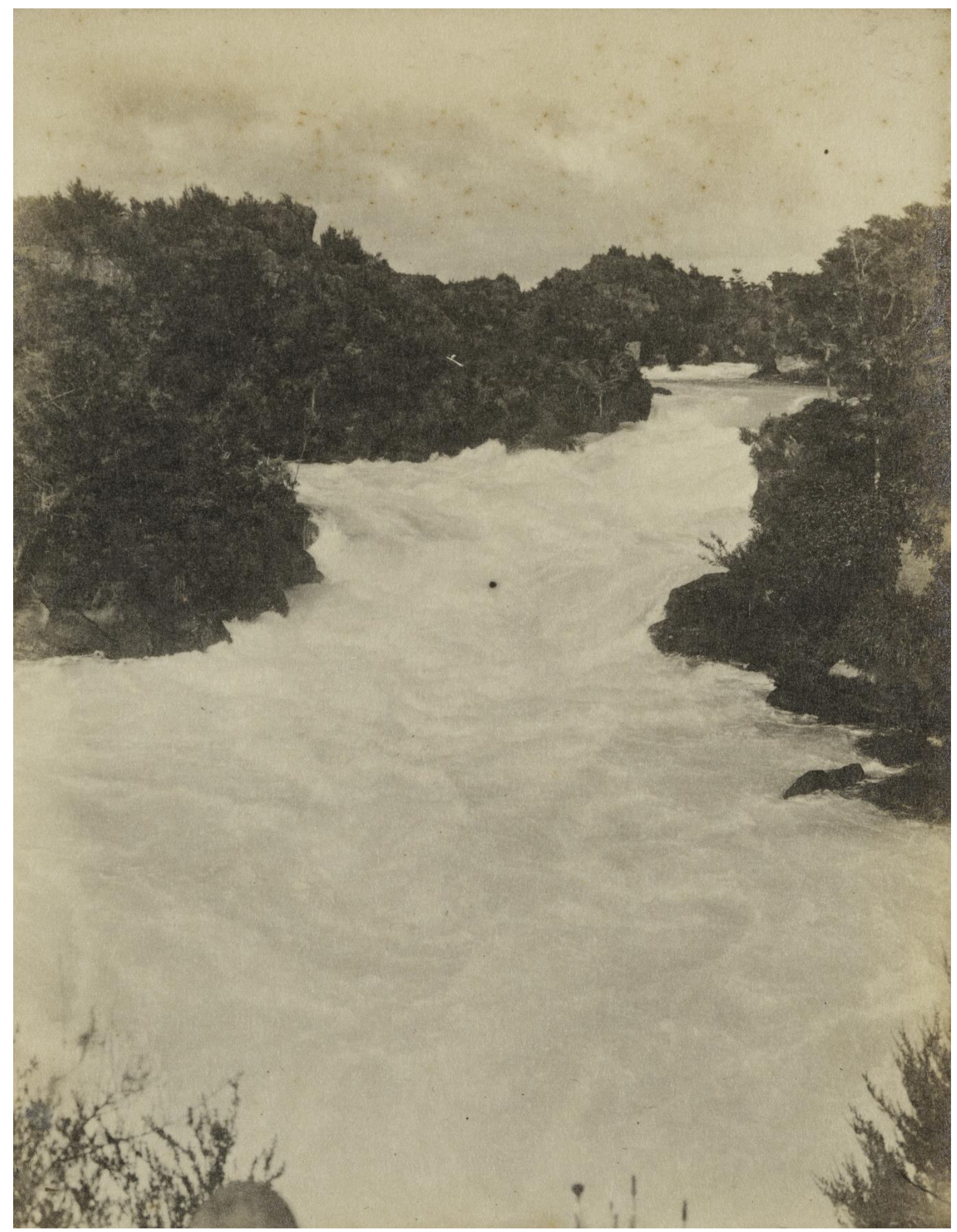

Image 23: The Huka Falls 


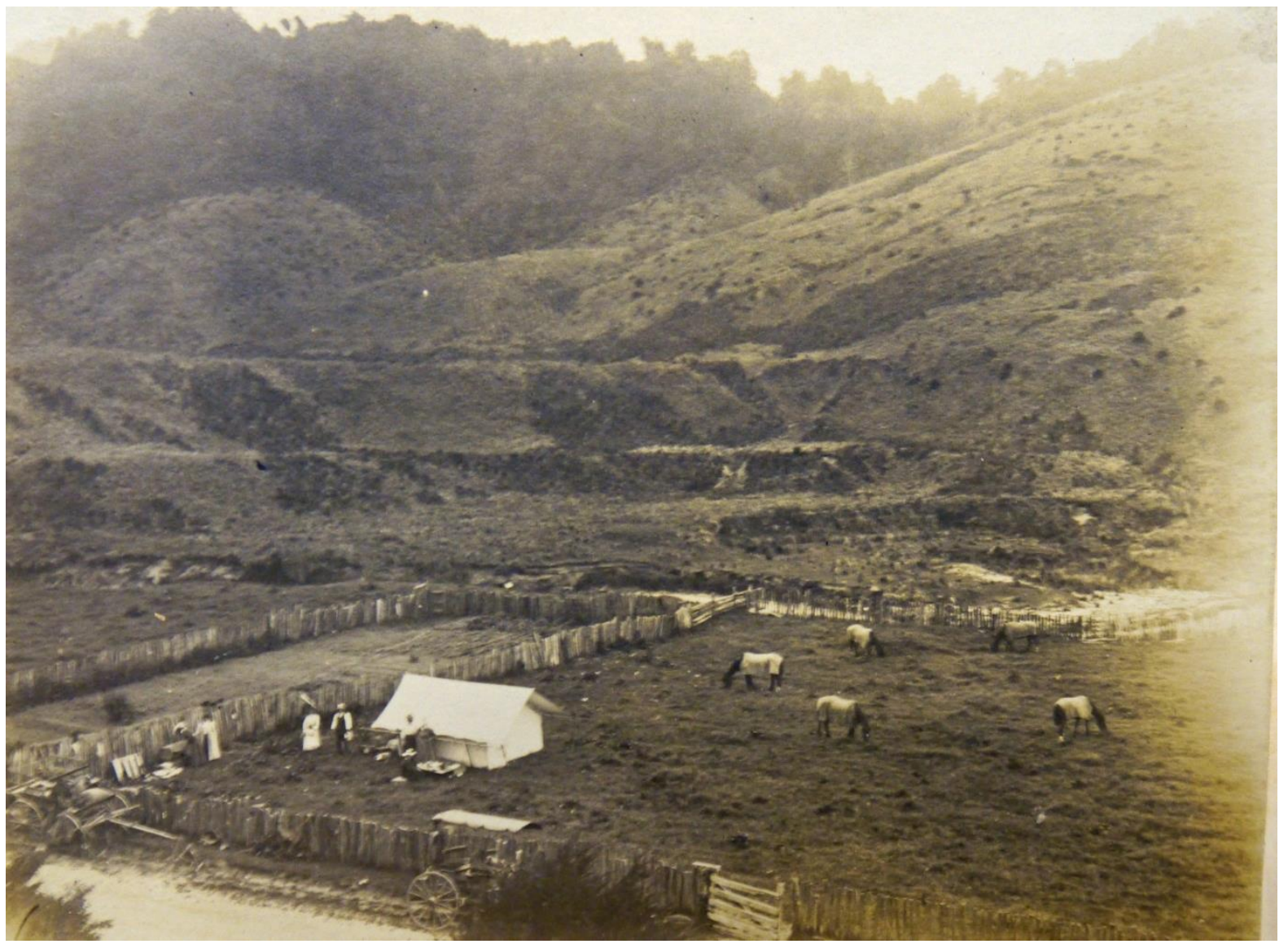

Image 24: Runanga, the site that Mansfield later adopted as the scene of 'The Woman at the Store'. Mrs Himing, her daughter and some of the other campers, are just visible standing beside the tent. 


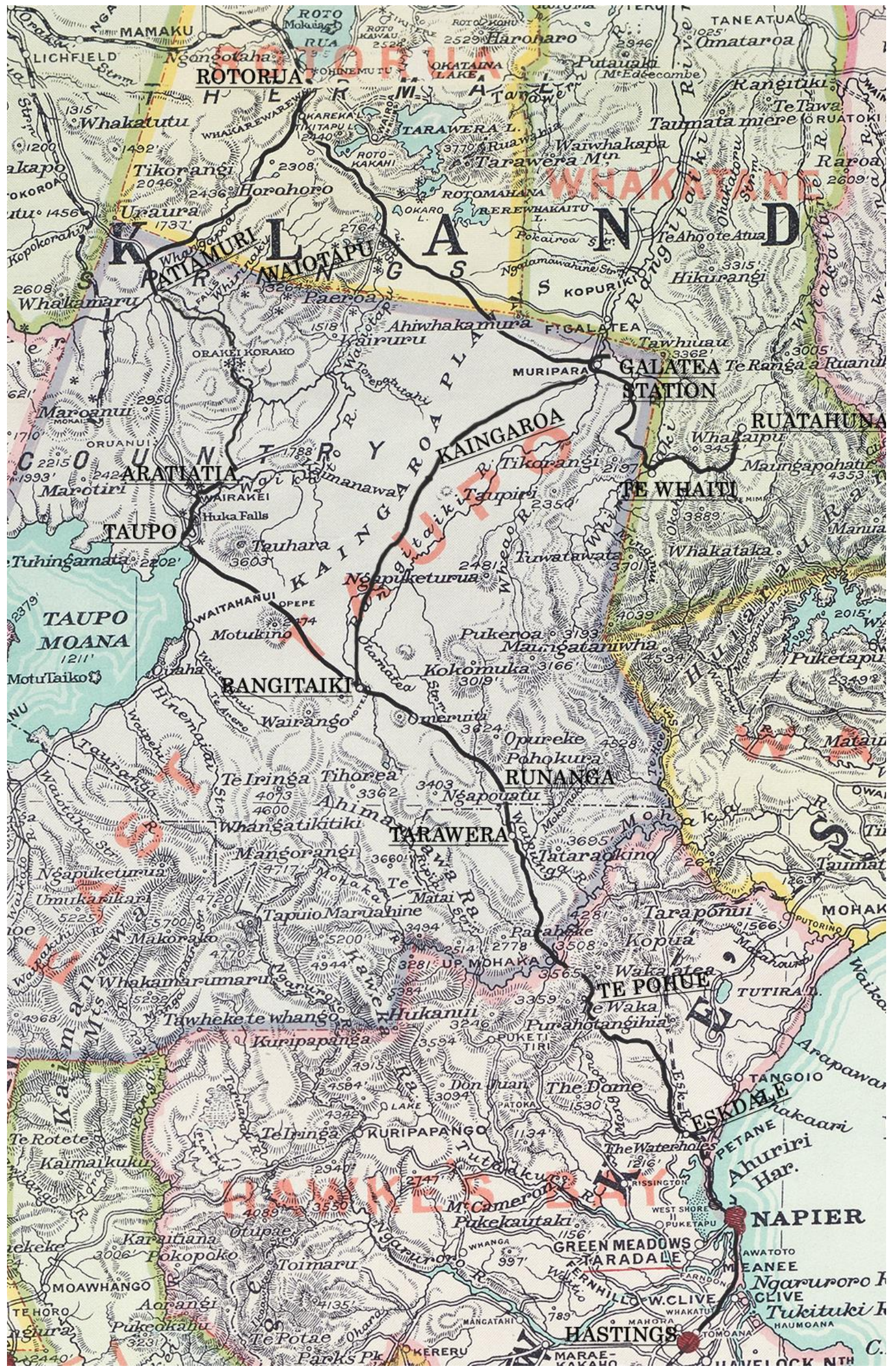

Image 25: Map showing the campers' route 


\section{$\underline{\text { Abbreviations in this Edition }}$}

\section{Edited works of Katherine Mansfield}

MM

M

G

S

KO’S1

KO'S2

O’SS1
Mantz, Ruth Elvish, and John Middleton Murry, The Life of

Katherine Mansfield (London: Constable, 1933)

Mansfield, Katherine, Journal of Katherine Mansfield 1904-

1922: Definitive Edition, ed. by John Middleton Murry

(London: Hutchinson, 1954)

Mansfield, Katherine, The Urewera Notebook, ed. by Ian A.

Gordon (Oxford; New York: Oxford University Press, 1978)

Mansfield, Katherine, The Katherine Mansfield Notebooks, ed. by Margaret Scott (Lincoln; Wellington: Lincoln University

Press and Daphne Brasell Associates, 1997)

Mansfield, Katherine, The Collected Fiction of Katherine

Mansfield, ed. by Gerri Kimber and Vincent O'Sullivan, 2 vols

(Edinburgh: Edinburgh University Press, 2012) 1

Mansfield, Katherine, The Collected Fiction of Katherine

Mansfield, ed. by Gerri Kimber and Vincent O'Sullivan, 2 vols

(Edinburgh: Edinburgh University Press, 2012) 2

Mansfield, Katherine, The Collected Letters of Katherine

Mansfield, ed. by Vincent O'Sullivan and Margaret Scott, 5

vols (Oxford: Clarendon Press, 1984) 1

\section{Newspapers}

AS

BA

Dom

EP

FL

$\mathrm{HBH}$
Auckland Star

Bush Advocate

Dominion

Evening Post

Freelance

Hawke's Bay Herald 
MT

$\mathrm{NZH}$

ODT

PBH

CHS

UKT

$\mathrm{WCH}$
Manuwatu Times

New Zealand Herald

Otago Daily Times

Poverty Bay Herald

Star (Christchurch)

Times $(U K)$

Wanganui Chronicle

\section{Manuscripts and personal communications}

Alexander MS

Webber MS

Ebbett MS

Parliament MS

Scott MS

Bland pers comm

Mason pers comm

Warbrick pers comm
Wellington, Alexander Turnbull Library, MSY-4600, New

Zealand Journals/Dudley Alexander

Wellington, Alexander Turnbull Library, MS-Papers-4010,

Elsie Webber to Henry Graydon Cook, 20 February 1956

Hastings, Ebbett Collection, Hastings District Libraries,

Ebbett, George, Notes on Early Hastings, N. d. TS

Wellington, New Zealand Parliamentary Library,

Parliamentary Library Daybook

Wellington, Alexander Turnbull Library, MS-Papers-6425,

Scott, Margaret. Papers re research on Katherine Mansfield

Bland, Dr Kyle, Personal communication (29 July 2013)

Mason, Te Haumihiata, Personal communication (9 December 2013)

Warbrick, Dr Paerau, Personal communication (27 June-11 July 2013)

\section{Government documents}

AJHR IC

Appendices to the Journals of the House of Representatives, 1908, I C-01a, pp. 1-143

AJHR ID

Appendices to the Journals of the House of Representatives, 1908, I D-01, pp. 1-113 
AJHR IH

Wai 33

Wai 201

\section{Other primary sources}

$\mathrm{CNZ}$

Fletcher

\section{Secondary sources}

Atkinson

Binney 1995

Binney 2009

Binney 2010

Bird

Boyd
Appendices to the Journals of the House of Representatives, 1907, I H-31, pp. $1-76$

Waitangi Tribunal, The Pouakani Report (Wai 33, 1993)

Waitangi Tribunal, The Mohaka ki Ahuriri Report (Wai 201, 2004) 1

The Cyclopedia of New Zealand: Industrial, Descriptive, Historical, Biographical Facts, Figures, Illustrations, 6 vols (Wellington: Cyclopedia Co., 1902) 2 Fletcher, Henry James, 'A Few of the Maori Wise Sayings From Lake Taupo', The Journal of the Polynesian Society, 31.1 (1922) 29-36

Atkinson, Neill, Trainland: How Railways Made New Zealand. (Auckland: Random House, 2007)

Binney, Judith, Redemption Songs: A Life of Te Kooti Arikirangi Te Turuki (Auckland: Auckland University Press and Bridget Williams Books, 1995)

Binney, Judith, Encircled Lands: Te Urewera, 1820-1921.

(Wellington: Bridget Williams Books, 2009)

Binney, Judith, Stories Without End: Essays 1975-2010.

(Wellington: Bridget Williams Books, 2010)

Bird, Henry Tahawai, Kuranui-O Ngati Manawa (Rotorua:

Rotorua Printers, 1980)

Boyd, Mary Beatrice, City of the Plains: A History of Hastings. (Wellington: Victoria University Press for Hastings

City Council, 1984) 
Brown

Coutts \& Grant

Crowe

de Charms

Ell

Keam

Mead

HB \& EC Museum

Orsman

Phillipps

Reed
Brown, Deidre, Maori Architecture: From Fale to Wharenui and Beyond (Auckland: Raupo, 2009)

Coutts, Brian and Don Grant, 'The New Zealand Surveyor The Twenty-first Century', Strategic Integration of Surveying Services: Fédération Internationale des Géomètres Working Week (Hong Kong: 13-17 May 2007) Conference Proceedings Crowe, Andrew, Which Native Tree? New Zealand Native Trees: A Simple Guide to their Identification, Ecology and Uses. (Auckland: Penguin, 2009)

De Charms, Leslie. Elizabeth of the German Garden (London, Heinemann, 1958)

Ell, Gordon, Rotorua: Text and Pictures (Auckland: Bush Press, 1995)

Keam, Ron, 'Warbrick, Alfred Patchett', in Te Ara, The Encyclopedia of New Zealand, <http://www.TeAra.govt.nz/en/biographies/

2w7/warbrick- alfred-patchett> [accessed 30 October 2013] Mead, Hirini Moko and Neil Grove, Nga Pepeha a nga Tipuna - The Sayings of the Ancestors (Wellington: Victoria University Press, 2001)

Historical Affairs Committee at the Hawke's Bay and East Coast Museum, Napier, 1855-1955: One Hundred Years on the Napier-Taupo Road (Napier: Venables, 1956)

Orsman, Harry ed., The Dictionary of New Zealand English: A Dictionary of New Zealandisms on Historical Principles (Auckland, Oxford University Press, 1997)

Phillipps, William John, The Book of the Huia (Christchurch:

Whitcombe and Tombs, 1963)

Reed, Alfred Hamish, The Story of Hawke's Bay (Dunedin: Reed, 1958) 
Stafford

Star \& Lochhead
Stafford, Don, The New Century in Rotorua: A History of Events from 1900 (Auckland; Rotorua: Ray Richards Publisher and Rotorua District Council, 1988)

Star, Paul and Lynne Lochhead, 'Children of the Burnt Bush: New Zealand and the Indigenous Remnant, 1880-1930', in Making a New Land: Environmental Histories of New Zealand, ed. by Eric Pawson and Tom Brooking (Dunedin: University of Otago Press, 2003) pp. 119-135 


\section{The Urewera Notebook}

[Notebook 2, qMS-1244]

[f. 1]

'Rien n'est vrai que le beau'

$\underline{\text { K. Mansfield - }}$

November 1907

[f. 1v] $\quad$ He huruhuru te manu ka rere -

K Mansfield -

4 Fitzherbert Terrace

Wellington

NZ.

\section{Rough Note Book}

A woman never ever knows when the curtain has fallen

OW.

1 beau] [beauté] S, whole line om. G; 4 He huruhuru ... rere] whole line om. G, S;

1 'Rien n'est vrai que le beau' Fr. 'Nothing is true but the beautiful', attributable to the poem 'Après une lecture' by French Romantic playwright and poet Alfred de Musset (1810-57), but recognised as an Aesthetic aphorism by 1907. Introduced into English literary circles by A. C. Swinburne in Essays and Studies (1876), it was further popularised as a signature statement of Oscar Wilde.

4 He huruhuru te manu ka rere Ma. From the whakatauki or proverb, 'He ao te rangi ka uhia, he huruhuru te manu ka tau' or 'As clouds deck the heavens, so feathers adorn the bird'. Credited to the famous Wairoa chief Tama-te-rangi, who refused to lead his men into battle until given chiefly garments appropriate to the occasion. Still cited to indicate an inability to attend an event 'because of a shortage of money or appropriate clothing', or as a mild rebuke to those appearing in unsuitable attire (Mead \& Grove, $65)$. In 1922, the proverb was recorded in the Polynesian Society Journal in the form 'he huruhuru te manu ka rere, he ao te rangi ka uhia' (Fletcher, 3) indicating that KM's wording was also in circulation. KM had already deployed the phrase in the poem 'In the Darkness', probably written 'on board the SS Niwaru en route to London in 1903' (S, 25).

10-1 A woman never ever ... OW. From The Picture of Dorian Gray in which Lord Henry declares, 'The one charm of the past is that it is the past. But women never know when the curtain has fallen.' In $1909 \mathrm{KM}$ used the same quotation as an epigraph to her unpublished story 'A Little Episode', in which Lady Mandeville's naïve joy at rekindling an old affair is contrasted with her lover's private cynicism. Kimber and O'Sullivan consider this story a literary exploration of KM's own 'bitterness and disillusion' (KO'S1, 544) after her abandonment by musician Garnet Trowell. However, KM had evidently been impressed by the phrase as early as 1907 . Her addition of the word 'ever' in the notebook and her substitution of 'a woman' for 'women' suggests that she recalled it imperfectly from memory in 1907 but had verified the reference two years later. 
[f.2] On the journey the sea was most beautiful - a silver point etching - and a pale sun breaking through pearl clouds -

There is something inexpressibly charming to me in railway travelling - I lean out of the window - the breeze blows, buffetting

and friendly against my face - and the child spirit - hidden away under a thousand and one grey City wrappings bursts its bonds $-\&$ exults within me - I watch the long succession of brown paddocks - beautiful with here, a thick spreading of buttercups - there a white sweetness of arum lilies - And there are valleys - lit with the swaying light of broom blossom - in the distance - grey whares two eyes \& a mouth - with a bright petticoat frill [f. 3] of a garden - creeping round them - On a white road once a procession of patient cattle - wended their way, funereal wise - and afar ${ }^{\wedge}$ behind them^ ${ }^{\wedge}$ a boy rode past on a brown horse - something in the poise of his figure - in the strong sunburnt colour of his naked legs reminded me of Walt Whit. Everywhere on the hills - great masses of charred logs - looking for all the world like strange fantastic beasts a yawning crocodile, a headless horse - a gigantic gosling a watchdog - to be smiled at and scorned in the daylight - but a veritable nightmare in the darkness - and now \& again the silver tree trunks - like a skeleton army, invade the hills -

At Kaitoki the train stopped for 'morning lunch-' the inevitable tea of the New Zealander The F.T. [f. 4] and I paced the platform peered into the long wooden saloon - where a great counter was piled with ham sandwiches \& cups \& saucers - soda cake and great billys of milk - We did not want to eat $-\&$ walked to the end of

15 buffetting] G, buffeting MM, M, S; 17 thousand] G, S, hundred MM, M; 22 bright] MM, M, S, light G; 24 funereal] G, S, funeral MM, funeral- M; 33 Kaitoki] G, S, Kaitoke MM, M; 36 piled] MM, M, S, filled G;

12 ff. Across the top margin of f. 2 appears the words 'Urewera - Kaingaroa Plains'. These probably served as a reminder rather than a heading; neither location relates geographically to the subsequent entry.

21 whares Ma. Houses, buildings.

22 two eyes \& a mouth Certain Maori oral narratives construe the architecture of a meeting house as the metaphorical body of an ancestor. The dissimilarity between KM's impression of a face and Maori symbolism, where 'the koruru (gable head) is the head; the maihi [bargeboards] are the arms' and 'the tahuhu (ridgepole) is the ancestor's backbone' (Brown, 52) suggests that KM was not drawing on these narrative traditions.

22 ff. [f. $2 \mathrm{v}$ blank]

25-27 a boy rode ... Walt Whit. Gordon proposed that KM alluded to the 'youthful sinewy races' and 'tan-faced children' of 'Pioneers! O Pioneers!' $(G, 101)$. She could equally have recalled 'O tan-faced Prairie Boy'. Both poems appear in
Whitman's Leaves of Grass (1867), which KM borrowed from the Parliamentary Library in Wellington in February 1907 (Parliament MS).

34 F.T. Fellow traveller (Millie Parker).

34 ff. In the first and third lines of f. $3 \mathrm{v}$, which is otherwise blank, appear the words:

[?Date]

Blue gigi for tatooing -

The phrase has been omitted from all previous editions of the Urewera Notebook. The word 'gigi' is unknown in the context of Maori tattooing but may reflect an imperfect Pakeha understanding of Maori pronunciation or traditional plant uses. Kiekie (Freycinetia banksii), a narrow-leaved climbing plant, was also known by the English variation 'gigi', pronounced 'ghi-ghi' (Orsman, 406) while the tall conifer Kahikatea (Dacrycarpus dacrydioides) had the anglicised abbreviation 'kike'. Kiekie was never used for tattooing, but the soot of burnt kahikatea was a common component of the tattoo's blue pigment (Crowe, 40). 
the platform $-\&$ looked into the valley - Below us lay a shivering mass of white native blossom - a little tree touched with scarlet $-\mathrm{a}$ clump of toi-toi waving in the wind - \& looking for all the world like a family of little girls drying their hair -

Later in the afternoon - we stopped at Jakesville - How we play inside the house while Life sits on the front door step \& Death mounts guard at the back.

[f. 5] After brief snatches of terribly unrefreshing sleep - I woke and found the grey dawn slipping into the tent - I was hot \& tired and full of discomfort - the frightful buzzing of the mosquitos - the slow breathing of the others seemed to weigh upon my brain for a moment and then I found that the air was alive with birds' song From far and near they called \& cried to each other - I got up - \& slipped through the little tent opening on to the wet grass - All round me the willow still full of gloomy shades - the caravan in the glade a ghost of itself - but across the clouded grey sky the vivid streak of rose colour - blazoned in the day - [f. 6] The grass was full of clover bloom - I caught up my dressing gown with both hands \& ran down to the river - and the water - flowed in musically laughing $-\&$ the green willows - suddenly stirred by the breath of the dawning day - sway softly together - Then I forgot the tent - and was happy ---

So we crept again through that frightful wire fence - which every time, seemed to grow tighter \& tighter - and walked along the white - soft road - A On one side the sky was filled with the sunset Vivid - Clear yellow - and $p$ bronze green $\&$ that incredible cloud shade of thick mauve - [f. 7] Round us, in the dark-ness, the horses were moving softly - with a most eerie sound - Visions of long dead Maoris - of forgotten battles and vanished feuds - stirred in me - till I ran through the glade - on to a bare hill - the track was

42 Later] M, late MM, G, S; 47 mosquitos] G, S, mosquitoes M; 53 vivid] M, S, first G; 58 breath] M, G, S, breathings MM; sway] G, swung MM, M, S;

40 toi-toi Cortaderia; toi-toi is a common misspelling of 'toetoe', a large grass with long scabrous leaves and feathery plume flowers.

42 Jakesville Presumably Woodville; 1907 maps and train timetables make no reference to 'Jakesville'. 42-4 How we play ... at the back KM frequently toyed with the personification of Death in her adolescent writing. Compare, for instance, her description of pine trees as 'fearful snowmen at the wedding with Death' in the latter part of the Urewera Notebook (S, 152) and two 1903 stories: 'His Ideal' (S, $7)$, in which Death forms a principal character, and 'Youth and Age', in which Age is kissed by 'the withered mouth of Death' (S, 203).

$45 \mathrm{ff}$. In the middle of $\mathrm{f} .4 \mathrm{v}$ there appears a pencil- sketch portrait of a girl in a wide-brimmed hat.

54 ff. [f. 5v blank]

65 ff. [f. 6v blank]

66-7 Visions ... feuds Gordon suggested that KM's visions were inspired by real events as narrated by George Ebbett (see: G, 37): in October 1866 a settler militia intercepted ' 30 well-armed' Hauhau Pai Marire 'rebels' in the Esk Valley, and in the ensuing skirmish 12 Maori were killed (Reed, 164). The Crown responded to the 'rebellion' by confiscating the Mohaka-Waikare district in 1867 (Wai 201, 165). Since only forty years separated such a well-recorded event from the camping trip, it seems doubtful that this conflict was the principal inspiration for KM's dreams of 'forgotten' battles. 
very narrow $\&$ steep - And at the summit a little Maori whare was painted black against the wide sky - Before her it - two cabbage trees stretched out phantom fingers - and a dog, watching me coming up the hill, barked madly - Then I saw the first star - very sweet \& faint - in the yellow sky - and then another \& another like little holes - like [?pin holes] [f. 8] And all round me in the gathering gloom the wood hens called to each other with monotinous persistence - they seemed to be hurt and suffering - I reached the whare - and a little Maori girl and three boys - sa sprang from nowhere $-\&$ waved $\&$ beckoned -- in the door a beautiful old Maori woman sat cuddling a cat - She wore a white handkerchief round her black hair - and vivid green \& black cheque rug wrapped round her body - Under the rug I caught a glimpse of a very bri full blue print dress - with native fashion the skirt of over the bodice -

[f. 9]

Petane Valley -

Monday morning -

Bon jour - Marie dearest - Your humble servant is seated on the very top of I know not how much luggage - so excuse the writing - This is a most extraordinary experience -

Our journey was charming - a great many Maoris on the train - in fact I lunched next to a great brown fellow at Woodville - That was a memorable meal - We were both starving - with that dreadful silent hunger - Picture to yourself a great barn of a place - full of pink papered chandeliers and long tables - decorated with paper flowers - and humanity most painfully en évidence [f. 9v] you could cut the atmosphere with a knife,

Then the rain fell, heavily drearily - on to the river \& the flax swamp $\&$ the mile upon mile of $p$ dull plains - In the distance - far and away in the distance - the mountains were eovered hidden behind a thick grey veil.

74 little holes - like [?pin holes]] little lilies - like primroses MM, little lilies, like primroses M, little holes like pinholes $\mathrm{G}, \mathrm{S} ; \mathbf{7 6}$ monotinous] monotonous $\mathrm{MM}, \mathrm{M}, \mathrm{G}, \mathrm{S} ; \mathbf{8 0}$ vivid] a vivid $\mathrm{MM}$, M, wore a $\mathrm{G}$, [a] vivid S; cheque] G, S, check M, M; 82 full] MM, M, S, pale G; with] S, worn MM, M, G; 93 pink] S, finely MM, primly G;

70-1 cabbage trees Cordyline australis, a tree with narrow leaves rising from a single trunk and creamy blossoms in densely packed panicles.

\section{4 ff. [f. 7v blank]}

75 wood hens Gallirallus australis, also 'weka', a brown flightless rail about the size of a chicken with a shrill, far-carrying call.

80-1 cheque rug Gordon noted that KM's spelling of 'check' was the telling mistake of 'a banker's daughter' (101).

84 ff. [f. $8 \mathrm{v}$ blank]

86 Marie The second of the Beauchamp children,
Charlotte Mary ('Chaddie') Beauchamp (1887-1966), was called 'Marie' on account of her resemblance to the English actress Marie Tempest.

89 Maoris on the train Maori were heavy train users by 1907, receiving concessions to attend tangi and Native Land Court hearings. (For the railway's impact on Maori society, see Atkinson, 18-187.)

94 en évidence Fr. conspicuous

96-9 Then the rain ... grey veil This section of text, divided by a blank line from the letter above, and abutting the 'Monday' entry below, has been treated differently by successive editors. Murry and Mantz, as 
Monday - The manuka and sheep country - very steep \& bare - yet relieved here and there by the rivers \& willows - and little bush ravines - It was intensely hot - we were tired \& in the evening arrived at Pohui where Bodley has the accomodation House - and his fourteen daughters grow peas - We camped on the top of a hill [f. 10] mountains all round $\&$ in the evening walked in the bush A beautiful daisy pied creek - ferns, tuis \& we saw the sheep sheds - smell \& sound - 12 Maoris - their hoarse crying - dinner cooking in the homestead the roses - the Maori cook - Post letters there see Maoris

Tuesday morning start very early Titi - o Kiura - the rough roads \& glorious mountains \& bush - The top of Taranga Kuma - rain in the morning - - then a clear day - the view mountains all round $\&$ the organ pipes - We laugh with joy all day - we lunch past the Maori pah $-\&$ get right into the bush - In the afternoon more perfect [f. 10v] bush \& we camp at Tarawera Mineral baths - the old man the candle in a tin - the scenery - the old shed - the hot water the feeling - the road - how we sleep -

Next day walking and bush - clematis \& orchids - meet Mary - by the ploughed field $-\&$ at last come to the Waipunga falls - the fierce wind - the flax \& manuka - the bad roads - camp by the river $-\&$ then up hill - the heat to Rangitaiki - Post letters - came on a peninsula - the purple - the ferns - the clean house - evening - the

103 Pohui] G, Pohue M, S; $\quad$ accomodation] G, S, Accommodation M; 110 Titi-o Kiura] Titiokiura M, Titi-oKura G, S; 111 Taranga Kuma] Tarenga M, Taranga-kuma G, Taranga-Kuma S; 112 view] G, S, wild M; 117 feeling] G, felling M, falling S; 118 Mary] M, S, Maori G; 121 came] Came S, camp M, G; 122 clean house] $M, S$, clear long G;

well as Scott, formatted this text as if it were a part of the preceding letter. Gordon considered it a separate entry describing 'the landscape on the way ... to Pohue' (39). Both are doubtful conclusions: the abrupt change of topic and tone is incongruous in the context of the letter to Chaddie, and the entry is an unlikely description of the mountainous route to Te Pohue. Possibly this text describes morning rainfall on the Kaingaroa Plains (1. 125) and is an example of KM's habit of backfilling empty spaces of her notebook.

100 manuka Leptospermum scoparium, a large shrub with small pointed leaves and clusters of white honey-scented flowers.

103 Bodley Henry Bodley (1855-1958) emigrated from England in 1878 and settled in Te Pohue in 1893. By 1907 he owned a local timber-mill, the Te Waka Station, an accommodation house, and had achieved such prominence that Te Pohue was frequently called 'Bodleytown'. He had three sons and eight daughters; KM's estimate of fourteen girls was an exaggeration (Parsons, 102-6).

106 tuis Prosthemadera novaeseelandiae, a bird with black feathers and iridescent sheen, a white tuft at the neck and melodic resonant song.

113 organ pipes Considered by Gordon to be KM's description of 'huge burnt trees, reminders of earlier eruptions' (102), this was more probably a reference to 'The Organs', a type of badlands rock erosion near the Mohaka River. The 1907 NapierTaupo Road followed a different route from the modern motorway and passed near 'The Organs' (Bland pers comm).

114 pah Ma. A variation of pa, a fortified Maori village or stockade. Historically used by Pakeha to indicate any Maori settlement, whether fortified or not, and here probably a reference to Te Haroto, although there were 'traces of many pa' in the region (HB \& EC Museum, 3).

116 the old shed The Tourist Department had in fact recently renovated this bathhouse: three baths had been constructed and the track 'greatly improved' under the supervision of Alfred Warbrick (see 1. 195) in October 1907 (PBH, 8 October 1907, 5).

118 Mary The identity of 'Mary' is unknown. 
cream - the wild pigs [f. 11] Woman and daughter - the man - their happiness - [?Discern] - Word - [illegible]

Thursday the plains - rain - long threading - purple mountains 125 river ducks - the clump of broom - wild horses - the great pumice fire - larks in the sun - orchids - fluff in the manuka - snow berries - After a time manuka \& a tree or two - more horses - it rains - violently - the fearful road - No water - Night in the tent - the rain - climbing to see where anything is - the quivering air - the solitude - Early bed - the strange sound - the utter back blocks - Fear [f. 11v] as to whether this was the rain - the store's breakfast - the kitchen - at night \& at morning - in wet clothes -

In the morning - rain first - the chuffing sound of the horses - we get up very early indeed - and at six o'clock - ready to start, the sun breaks through the grey clouds - There is a little dainty wind and a wide fissure of blue sky. Wet boots - wet motorveil - torn coat - the dew shining on the scrub - No breakfast - We start - the road grows worse \& worse - we seem to pass through nothing but scrub covered valleys - and then suddenly comes round the corner a piece of road - Great joy but the [f. 12] horses sink right into it the traces are broken - it grows more \& more hopeless - The weather breaks \& rain pours We lose the track again and again become rather hopeless - when suddenly far ahead we see a man on a white horse - The men leave the trap \& rush off. By and by through the track we met two men Maoris in dirty blue ducks - one can hardly speak English - They are surveyors - We stop - boil the billy \& have tea $\&$ herrings Oh! how good - Ahead the purple mountains - the thin wretched dogs - we talk to them - thin. We drive the horses off but there is no water - the dark people the conversation $-\mathrm{E}$ ta - Haeremai te kai - it is cold.

124 [?Discern] - Word - [illegible]] forgive Lord - I can’t G, Solemn word - Facial[?] S; 127 larks] M, G, lambs S; 127-8 snow berries] M, S, strawberries G; 132-3 the store's breakfast] Hector's breakfast M, we close tent fast $\mathrm{G}$, the close[?] breakfast $\mathrm{S} ; \mathbf{1 3 4}$ first] G, S, fast MM, M; 137 torn] MM, M, S, wet G; 141 sink] M, G, S, rush MM; 145 trap] M, G, S, cart MM; 149 thin] S, Then MM, M, thin G; 151 Haeremai] G, S, hoeremai MM, haeremai M;

124 [?Discern] ... [illegible] Gordon's reading of 'Forgive Lord, I can't' is unlikely; there is certainly no letter ' $\mathrm{g}$ ' in the word he transcribes as 'forgive'. This undermines his claim that the line refers to the 'marital discord' of the landlord and his wife at the Rangitaiki Hotel, and that this 'discord' was the inspiration for 'The Woman at the Store' (46). His interpretation is especially dubious given KM's previous reference to the family's 'happiness'.

127-8 snow berries Gaultheria oppositifolia, or 'Tarawera snowberry', a sprawling shrub bearing clusters of white bell-shaped flowers, found only in the central North Island.
145 trap The travelling coach. 147 surveyors A large number of surveys were carried out in the North Island in 1907 due to the 'unceasing demand for land' (AJHR I C, 1) and a network of 'tourist roads' was being constructed around Murupara (AJHR I D, 28). These men were probably members of the survey work gang: surveying was a profession regulated by statute in 1907 and survey cadets sat rigorous examinations necessitating a high level of English proficiency (Coutts \& Grant, 3).

151 E ta-Haeremai te kai Ma. 'Come and have some food'. Compare 1. 731 where KM has the translation: 'I say, come to eat'. 
[f. 12v] the crackling fire of manuka - walking breast high through the manuka.

lily of the valley - the ti tree - we approach Galatea - We lunch by the Galatea River. There is an island in the centre - and a great clump of trees - the water is very green and swift. I see a wonderful huge horsefly - the great heat of the sun - and then the clouds roll up.

"Mother's little lamb, isn't 'e" she said - tossing the baby up in the air -

"When 'e's asleep", cried the girl - bringing a clean pinafore and a little starched bib -

"Hold the horses or they'll make a bolt for the river -" My fright

[f. 13] Encounter one man surveyor on white horse - his conversation - raupo whare in distance Picture - At the city gates we pull up, \& walk into the 'city'. There is a store - an Accomodation House - and a G.P.O. Mrs Prodgers is here - with the Baby - and other Englishmen - it is a lovely river - the Maori women are rather special - the Post-boy - the children - an accident to the horses - very great - the Maori room - the cushions. Then a straight road in a sort of basin of stony mountains -

Far away in the distance a little c. cloud shines in the sunlight Through the red gate there were waving fields $-\mathrm{a}$ fresh [f. 13v] flax swamp - the homestead in the distance - tree encircled - a little field of sheep - willow and cabbage trees \& away in the distance the purple hills in the shadow - sheep in for shearing - Here we drive in and ask for a paddock - Past the shearing sheds - past the homestead - to a beautiful place - with a little patch of bush - tuis magpies - cattle - and water running through - But I know from -

154 ti tree] ( ) MM, [illegible] M, ti pore G, ti tree as S; 157 huge] M, G, S, great MM; 161 bringing] G, $S$ wearing $M ; 165$ raupo whare in the distance Picture] raupo whare in the distance - Picture G, raupo whare in the distance. Picture S; Nango (?) whare, in distance Picton M; 167 Accomodation] G, S, Accommodation MM, M; 171 straight] G, S, strange MM, M; stony mountains] G, S, strong underbush MM, M;

154 ti tree A name given to several unrelated plants. Here probably used as a common variant of 'tea tree', a European name for both manuka (see 1. 100) and kanuka (Kunzea ericoides) a tree similar to manuka but with softer leaves and smaller flowers.

163 "Hold the horses ... fright Millie Parker recalled how, after emerging from the dusty plains, the campers' first care was 'for the weary horses. Each one was given a small drink from a bucket, so that they should not drink too much in their frantic haste, and it was most difficult and troublesome to hold them' (NZH, 21 March, 1931, 4).

165 raupo whare Ma. A house with bulrush cladding.

173 ff. In the top margin of $\mathrm{f} .13 \mathrm{v}$ appears the word 'Murupara'.
167-8 Mrs Prodgers ... Baby Dorothy Prodgers, née Lees (1877-1934), was the eldest daughter of Charles Edward Lees (1840-94) of Werneth Park, Oldham, a prosperous spinning and textile manufacturer, and Dame Sarah Anne Lees (1842-1935), a key figure in the British women's suffrage movement and local politician. In 1903 Dorothy had married the Reverend Charles Prodgers (see 1. 277) and by 1907 had a daughter, Eva.

170 the Maori room William Henry Bird (18621947), a carpenter and bridge builder, operated the store in Murupara, and managed the post office with his daughter Rangiora. It was his wife, Kiekie Hopaia of Ngati Manwa, who managed the accommodation house and presumably furnished it in the Maori décor that caught KM's attention. (Bird, 2). 
bitter experience that we shall be eaten with mosquitos Two Maori 180 girls are washing - I go to talk with them - they are so utterly kids - While the dinner cooks I walk away - and [f. 14] lean over a giant $\log$. Before me a perfect panorama of sunset - long sweet steel like clouds - against the faint blue - the hills full of gloom a little river with a tree beside it, is burnished silver - like the sea the sheep and a weird passionate abandon of birds - the bush birds' cries the fanciful shapes of the supple jacks - - - -

Then the advent of Bella, her charm in the dusk, the very dusk incarnate. Her strange dress - her plaited hair \& shy, swaying figure - The life they lead here -

In the shearing sheds - the yellow dress with huia feathers on the coat [f. 14v] \& a skirt with scarlet rata blossom - the speed - heat -- new look of the sheep - Farewell -

The road to Te Whaiti -

Meet the guide.

wild strawberries.

the pink leaved ferns

matai -

Lunched at a space in the bush cut through a tree - and then by devious routes we came to the pah - It was adorable - Just the collection of huts, the built place, for koumara \& potato - We visit first the house - no English then a charming little place roses \&

186 the bush birds'] [illegible] M, their † strange G, the bush birds S; 191 huia] G, S, tui MM, blue M; 192 \& a skirt with scarlet rata blossom] and ( ) with scarlet ( ) blossom MM, and skirt with scarlet blossom M, jacket with scarlet rata blossom G, S; 193 new] G, and MM, M, S; 198 matai] Matai G, S, WAKI MM, Waki M; 201 koumara] G, S, Koumara MM, kumara M;

187 supple jacks Ripogonum scadens, a vine with thick tangled stems, jointed like bamboo.

188 Bella Despite speaking with several kaumatua from the Galatea region, my attempts to uncover the identity of 'Bella' have proven inconclusive: as an itinerant farm-worker, she could have come from as far afield as inland Urewera.

191-2 huia feathers on the coat The huia (heteralocha acutirostris), now extinct, was a black wattlebird with bright orange wattles at the gape, and long white-tipped tail feathers. These feathers were traditionally worn by Maori people of high rank. By 1907 they were worn by those "who considered they had any claim to chiefly rank', but were generally reserved for important occasions, such as royal visits and 'tangi' (Phillipps, 39). KM's description of 'huia feathers on the coat' may have been a reference to a material design: Binney has drawn attention to Urewera women wearing 'huia-feather-pattern' dresses in 1904 (Binney 2009, 477).

195 the guide Alfred Patchett Warbrick (18601940), second son of English emigrant Abraham Warbrick, a trader near Matatua, and Ruhia
Ngakarauna of Ngati Rangitihi. Through his father's friendship with Donald McLean, then Minister of Native Affairs, Alfred Warbrick was apprenticed to an Auckland boat builder in 1874. After he witnessed the 1886 eruption of Mt Tarawera he became a guide in Government employ, escorting tourists through the posteruption terrain and participating in a number of daring exploits amongst the geysers. In 1888 he toured Great Britain as part of the New Zealand Native Football Team (Keam). KM was clearly impressed by the venturesome Warbrick: in December 1908 she wrote in her journal, 'I should like to write a life much in the style of Walter Pater's 'Child in the House' ... Bring into it Warbrick the guide' ( $\mathrm{S}, 111-2)$.

197 pink leaved ferns Blechnum novaezelandiae, or kiokio, a large fern common in lowland forests, with pink fronds that turn green with age.

198 matai Prumnopitys taxifolia, a spindly bush that grows into a tall coniferous tree with bark of a distinctive 'hammer mark' pattern.

201 the built place A pataka or storehouse for food raised upon posts

201 koumara Ma. kumara, sweet potato. 
pinks in the garden - Through the doorway the kettle \& fire $-\&$ bright tins - the woman the child in the pink dress \& red sleeves in all this black grey [f. 15] How she stands gathering her pleats of dress - she can say just 'Yes' - Then we go into the parlour photos - a chiming clock - mats - kits - red table cloth - horse hair sofa - The child saying "nicely thank you" the shy children - the Mother \& the poor baby - white \& naked - the other bright children her splendid face \& regal bearing - Then at the gate of the P.O. a great bright coloured crowd - almost threatening looking - a follower of Rua with long Fijian hair \& side combs a most beautiful girl of 15 - she is married to a patriarch, her laughing face, her hands playing with the children's hair - her smiles - across the bad river - the guide the swimming dogs - it flows on [f. 15v] he stands in the water a regal figure then his 'alight' \& we are out - the absolute ease of his figure - so boneless he speeds our parting journey his voice is so good - He speaks most correctly and yet enunciates each word. We see him last stopping to rest his horses - then a mound of tutu - amazingly emerald in colour the sun is fearfully hot - We camp by the guide's whare the splendour of the night - the late fire - those [?insights] Then the birds calling through the night.

${ }^{\wedge} \underline{\text { Sunday }} \wedge$ A splendid morning - washing in the creek - Leave early - leaving some luggage - on the way to Matatua - the silver [?tree]. The [f. 16] white flower that Elysian valley of birds - the red tipped ferns - the sound of the shots - then almost a bare hill [illegible]

204 child] MM, M, S, children G; 205 in all this black grey] ( ) MM, in the background M, and all the background $\mathrm{G}$, in all this vast[?] glory $\mathrm{S} ; \quad 207$ chiming] M, G, S, charming MM; 209 poor] MM, M, G, brown S; white] M, thin MM, G, S; 215 bad] M, G, S, broad MM; 217 'alight'] alight MM, 'All right!' $\mathrm{M}$, alright $\mathrm{G}$, alight $\mathrm{S}$; boneless] MM, M, S, fearless, G; 218-9 He speaks most correctly and yet] S, He speaks most correctly and MM, he speaks most correctly and yet $\mathrm{M}$, when he speaks - most correctly and yet G; 220 rest] MM, brush $M, G$, rub $S$; then a mound of tutu] near a mound of tui $M$, near a mound of tutu $G, S$; 222-3 those [?insights]] whole of night G, broken snippets $S$; 225-6 [?tree]. The] beech - the G, birch, thick S; 227 shots] shot, and G, chocks S; [illegible]] among G, S;

207 kits English variation of 'kete'. Ma. Baskets woven from flax strips.

212 follower ... combs Rua Kenana (1869-1937), the Tuhoe religious leader who claimed to be the subject of the prophecy made by the founder of the Ringatu faith, Te Kooti Arikirangi, that his successor would redeem the land for Maori (Binney 2010, 87). In 1907 Rua founded a religious community at Maungapohatu in the Urewera in conscious recreation of the biblical city of Jerusalem. Between 1907 and 1915, Rua's followers, the 'Iharaira', signalled their dedication to God by growing their hair long in imitation of the Nazarites (89).

220 tutu Coriaria arborea, a straggling plant with glossy leaves and poisonous purple berry-like fruit in hanging racemes.

222 guide's whare This was the house of Albert Warbrick (1857-1932), eldest and only surviving brother of Alfred Warbrick. He served as 'foreman', overseeing the construction of roads in the Urewera (EP, 12 March 1904, 10). His descendants recall that he operated a stage-coach business, transporting mail and goods through the North Island and was living in Te Whaiti on rented land in 1907; his own homestead was near Murupara (Warbrick pers comm).

226 ff. Across the bottom margin of f. 16 appears a puzzling phrase: '[illegible] know what [?over look]'. Gordon considered the phrase a part of the main entry but 'indecipherable' (55). Scott also considered it part of the main entry, reading: 'the knob whare down into[?]' (S, 140). Because of its placement, I consider this phrase to be marginalia.

227 shots Elsie Webber recollected Ebbett catching a pheasant near Te Whaiti: 'Mr. Ebbett got his gun and shot it. It fell in the river. My husband dived into 
green [?hills] winter bare tree trunks \& a strong blue sky We saw a little flock of white sheep such a whare on a hill \& carved too, but no one is at home, though there is a suggestion of fire, lately. From this saddle we look across mile upon mile of green bush then brown bush russet colour - blue distance - and a wide cloud flecked sky - All the people must doubtless have gone shearing. I see none ---Above the whare there is a grave a green mound - looking over [f. 16v] the valley - the air - the shining water - then sheep - quiver $\&$ terror stricken flee before us. Once at the head of a great valley - the blazing sun uplifts itself - like a gigantic torch to light the bush - it is all so gigantic - and tragic - even in the bright sunlight it is so passionately secret and it has the entirely [?frightful] [illegible] look. We begin to reach the valley-road A green-red \& brown butterfly, the green hill in vivid sunlight $\&$ then a vault of green bush the sunlight slanting in to the tree - an island in the river decked with tree fern - And always through the bush - this hushed sound [f. 17] of water running - on brown pebbles - it seems to breathe the full deep - bygone essence of it all - a fairy fountain of golden rings - then rounding a corner we pass several little whares - deserted - \& grey - they look very old - and desolate - almost haunted - on one door there is a horse collar on a torn or scribbled notice - flowers in the garden one clump of golden broom - one clump of yellow irises -

Not even a dog greets us - all the whares look out upon the river \& the valley $\&$ the bush gloried hills. These trees smothered in cream blossom

[f. 17v] Blue skirt - great piece of greenstone black hair, beautiful bone ear rings -

We plunge back into the bush \& finally reach a village - several whares - deserted now but showing signs of recent habitation a white cow \& her calf are tethered to the side of the road \& a brown

228 [?hills] hills G, S; strong blue] G, stone colour S; saw] S, meet G; 229 such] S, and G; carved] M, S, called G; 231 mile upon mile] M, S, river upon river G; brown] S, burnt M, G; 233 none] M, S, no one G; 236 quiver] swift and G, quite $S ; \quad$ Once] once G, while $S ; \quad 239-40$ it has the entirely

[?frightful] [illegible] look] [several words indecipherable] G, here[?] the entirely thoughtful [?] look S; 240 begin] begin G, go again S; valley-road A green - red \&] valley - broad and green - red and G, valley-road. A green red \& S; 241 hill in vivid sunlight] S, place in vivid sunlight $G$, hill a river superb S; a vault] S, silent and G; 243 decked] S, arched G; 245 fountain] M, S, formation G; 246 golden rings] G, S, green moss M; 254 beautiful] S, white and red G; 256 village] whare G, S;

the water and retrieved it. Shortly afterwards a man rode up on horseback ... Mr. Ebbett said to him, "You are not by any chance the ranger?" "As a matter of fact I am", he said. His name was Warbrick, a halfcaste. We felt very foolish but he allowed us to keep the pheasant which was enjoyed immensely' (Webber MS). KM's note about 'shots' may refer to a second, similar shooting episode.

233 people ... shearing

Another explanation for the scarcity of inhabitants was offered by Elsdon Best, acting as Government Sanitary Inspector in 1907: 'All Natives have been warned by Rua to leave their homes, sell all portable property, and go and live on the hills in order to avoid an appalling deluge which is soon to overwhelm all low-lying lands' (AJHR I H, 58).

254 ff. Across the top margin of $\mathrm{f} .17 \mathrm{v}$ appear the words 'Oh, what a comfort.' 
cow \& a brown calf - a grey mere \& a preposterous looking little foal are the sole inhabitants - - there is a great open clearing here -

and we decide to pitch the tents -

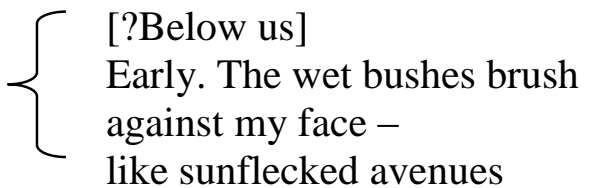

The new bracken is like H.G. Wells dream flowers, like Strings of Beads [f. 18] the sky in the water is like white swans in a blue mirror.

We [?pluck] 'nga moui' with the Maori children - in the sunshine Their talk \& their queer, droll ways. They laugh very much at us, but we learn, too, - tho it is difficult - and tedious, too, because our hands are so stiff - One girl is particularly interesting with auburn hair and black eyes. She laughs with an indescribable manner and has very white teeth. Also another Maori in a red \& black striped flannel jacket - the small boy is raggedly dressed in brown - his clothes are torn in many places - he wears a brown felt hat with a - [f. 18v] 'koekoea' feather placed rakishly to the side-Here, too, I meet Prodgers,

259 preposterous] S, grey and brown leading a G; 262 [?Below us]] We are up G, Bright and[?] S; 265 like] S, and G; 269 [?pluck] 'nga moui']l pick Ngamoni MM, pick nga-moni M, play 'Nga maui' G, pluck 'nga maui' S; 276-7 'koe-koea'] G, S, koe-koe MM koe-koea M;

266 H.G. Wells Gordon proposed that the unfurling bracken leaf may have reminded KM of the early pages of The Food of the Gods (1904) which were 'illustrated with zig-zag diagrams' (103), but KM's allusion is probably to the 'delicate and wonderful flowers' which prove the Time Traveller's journey into the future in The Time Machine (1898).

269 [?pluck] C.K. Stead has offered another reading of this word which, he said, 'undoubtedly begins with 'pl', probably followed by 'an 'e' and an 'a' pushed together to form 'pleach': he conceded this was 'unusual' but had the advantage of making sense' (Stead, 220-1) since 'pleach' refers to the interlacing of stems or boughs of a tree. At a superficial glance, the word seems, rather nonsensically, to read 'plack' or 'plach' and even after persistent scrutiny eschews any straightforward interpretation, as demonstrated by the diverse readings of successive transcribers.

269 nga moui Ma. 'whai wawewawe a maui', sometimes abbreviated to 'nga maui', is a string game traditionally associated with Maui, the trickster hero of Maori legend. Unless Mansfield's spelling of 'moui' is an inadvertent error, her inaccurate spelling suggests she was picking the term up by ear.

272 auburn hair The prevalence of red hair amongst the Urewera tribes was frequently described by visitors and fed into the debate on Maori somatology. Dudley Alexander, private secretary to
Lord Ranfurly, travelling through the Urewera in 1904, noted that 'a great many of the women have reddish hair. There is a theory that 500 or 600 years ago, when the Maoris came to New Zealand they conquered a former race who were red-headed, and this coloured hair has remained with the Ureweras ever since' (Alexander MS).

276-7 'koe-koea' Eudynamys taitensis, the migratory long-tailed cuckoo, whose long black and brown barred tail-feathers, traditionally valued as hair ornaments, were the emblem of Ngati Whare.

277 Prodgers Charles Henry Prodgers (18671940), was rector of Elvaston in Derbyshire with the comfortable living of Thurleston Grange (UKT, 21 October 1898, 6). His father was a member of the British peerage and his younger sister made an advantageous marriage to John Forbes-Sempill, 18th Lord Sempill and 9th Baronet of Craigievar. This brought Prodgers into frequent contact with the British aristocracy. He was a member of the Royal Yacht Squadron and a keen traveller. He made his first visit to New Zealand in 1901 for 'the benefit of his health ... angling and sight-seeing' (ODT, 2 December 1901, 5). On his second visit (April 1907June 1908) he spent several months fishing and hunting in the Urewera and at Galatea, 'camping out in fine weather, and returning to Bird's [accommodation house] when the elements were un- 
it is splendid to see once again - real English people - I am so tired $\&$ sick of the third rate article - Give me the Maori and the tourist - but nothing between - Also this place proved utterly disappointing after Umuroa, which was fascinating in the extreme - the Maoris here know - some English and some Maori - not like the other natives - Also these people dress in almost English clothes compared with the natives here - and they wear a great deal of ornament in Umuroa \& strange hair fashions - I found nothing of interest here -

[f. 20] Well Mother - I posted your letter at the Rangateiki Hotel On the way out I saw the land -lord's wife - and knowing that she was a happy Mamma, questioned her as to her offspring.

[f. 19] we lunch and begin to decide whether to go to the Wharepuni 290 - the men folk go - but eventually come back and say that the walk is too long - also the heat of the day - but there is a great pah $-1 \frac{1}{2}$ miles away - There we go - The first view - a man on the side of the road - in a white shirt [f. 19v] and brown pants - waits for us opposite is a thick bark Maori fence - in the distance - across the paddock several whares clustered together like snails upon the green patch - And across the paddock a number of little boys come straggling along from the age of twelve to three - out at elbow bare footed - indescribably dirty - but some of them almost beautiful - none of them very strong - There is the great fellow Iariri - who speaks English - Black curls clustering around his broad brow - rest almost languor in his black eyes - a slouching walk \& yet there slumbers in his face - passion might [f. 20] and strength. Also a little chap in

280 Also] M, G, S, All MM; 284 here] MM, M, [t]here G, S; 285 Umuroa] M, G, S, Muroa MM; 287 Rangateiki] Rangitaiki G, om. S; 288 knowing] thinking G, om. S; 289 Mamma] woman G, om. S; 295 bark] ( ) MM, black G, bark[?] S; 299 almost] MM, S, G, are almost M; 301 Iariri] Feropa MM, ... M, I see $\mathrm{G}$, Isaiah $\mathrm{S} ; 302$ broad brow] MM, G, S, head band M; 303 passion might] $\mathrm{G}$, S passionate unrest MM, $\mathrm{M}$;

favourable' (Dom, 3 March 1908, 4). Murry and Mantz asserted that KM had met Prodgers in 1900 while at the Fitzherbert Terrace School, and that he 'wrote in her album' (153), but offered no explanation for the source of their information.

287 ff. In the top right-hand corner of f. 20 appear the words:

Monday.

Monday.

Kaitoki

Beside this is a cartoon figure in a plumed hat and three-dimensional cube. A roughly etched line divides these words and sketches from the draft letter beneath. 287-9 Well Mother ... offspring KM deleted this draft letter by means of a single strike-through. Gordon alleged the subject of this draft was the situation at the hotel back in Rangitaiki' with which KM was still 'concerned' (61). This reading relied on his various misreadings ('thinking' instead of 'knowing, and 'woman' for 'mamma'). In fact nothing within this letter, when properly transcribed, concerns marital disharmony.

290 Wharepuni Ma. Principal house of a village, guest or sleeping house. Gordon suggested that this was the wharepuni erected at Mataatua in 1888, but this is disputable. (See Itinerary, p.70).

301 Iariri Possibly a misconstruction of 'Ariki', meaning lord or chief and sometimes a component in a proper name. Given the diversity of pre-contact Maori names, Iariri may also have been a name in its own right, translating roughly as 'seething waters' (Mason pers comm). 
on Tuesday Monday night we slept outside Warbrick's whare -

rather sweet Mrs Warbrick is such a picture in her pink dressing gown her wide elastic hat her black fringe the hands are like carving - She gives as a great loaf of bread - leans swaying against the wire fence - in the distance I see the niece Johanna - watering her [f. 20v] garden with a white enamel teapot - She is a fat wellmade child in a blue pinafore - her hair plaited \& most strange eyes. Then she milks the cows $-\&$ Wahi brings us a great bowl of milk \& a little bowl of cream - Also a cup of curd - She dines with us - teaches me Maori \& smokes a cigaret Johanna is rather silent reads Byron \& Shakespeare \& wants to go back to school - W teaches her fancy work. At night we go \& see her - the clean place - the pictures - the beds - Byron \& the candle - the flowers in a glass - sweet - the paper \& pens - photos of Maoris \& whites - too - Johanna stays by the door we see her jewellery, her Mothers -

[f. 21] I got a Maori kit. [?WW] thinks the old people at Umuroa so dirty - yes - Would I like to sleep there? Hot water - Home in the dark - Johanna more silent - there is something sad about it - all she is so lovely. Next day they see us off - I hear [f. 25v] the guide's horse going in the night. She has been up very early - J. is shyer today - she talks to the little boy from over the road - And the boy's Mother comes - a worn but rather beautiful woman who smiles delightfully, Yes - she has five children tho she looks so young \& the girl is shearing now - It is in winter that it is so cold - all snow $-\&$ they sit by the fire - never go out at all - just sit with many clothes on \& smoke - Farewell Johanna again waters the flowers soon she will go to milk the cow $-\&$ then begin again - I suppose -

310

315

320

325

[f. 19] So we journey from their whare to Waiotapu - a grey day \& I drive - long dusty thick road \& then before us Tarawera - With the great white cleft - The poverty of the country. But the gorgeous blue mountains all round is a great stretch of burnt manuka -

307 elastic] [illegible] M, native G; 312 bowl] M, cup G, S; 313 curd] S, lard M, G; 319 Mothers] clothes M, G, S; 320 [?WW]] W G, S; 323 lovely] M, lonely G, S; 324 going] G, coming S;

306 Mrs Warbrick Heeni Poraka (1860-1916), also known as Jane Stirley, daughter of Captain Samuel Stirley and Tipare Stirley of Ngati Porou. 309 Johanna Joanna Kaua Hill (1894-1921) was the daughter of Turea Hayes and Marara Kaua, who were of Ngati Porou and European descent. She bore the surname 'Hill' following her mother's remarriage to John Smith Hill. Joanna lived with her grandmother, Hoana Te Awakehe, and after her death, stayed with her Warbrick relatives. She later qualified as a teacher, taught at various 'native schools', and eventually became headmistress of Whakawhitira Native School, before succumbing to tuberculosis. Her grave stands alongside those of her
Warbrick relatives at Te Teko in the Bay of Plenty (Warbrick pers comm)

320 ff. In the top right-hand corner of f. 21 appears the word 'Tuesday.'

$320[$ ?WW $\quad$ An ambiguous cluster of letters, at least one of which is ' $W$ '. Gordon and Scott read the markings as ' $\mathrm{W}$ ', and considered it an abbreviation for 'Mrs Webber'.

332 ff. In the first two lines of f. 19 appear the words Johanna Hill Warbeck.

Galatea. Longfellow -

334 white cleft A series of deep fissures formed on Mount Tarawera during its eruption in 1886, leaving a rift of ten miles across its summit. 
[f. 21v] On the journey to Waiotapu - In the distance these hills to the right, almost violet, to the left grey with rain - Behind a great mount of pewter colour and silver. And then as we journey a little line of brilliant green trees - and a mound of yellow grass. We stop at a little swamp to feed the horses - and there is only the sound of a frog - Tense stillness - almost terrible - Then the mountains are more pronounced - they are still most beautiful and by and bye a little puff of white steam - we pass the Prison Tree Plantations and by turns \& twists the road pass several steam holes - Perfect stillness - and a strange red tinge in the cliffs - the baked ribbing of the earth showing through. [f. 22] We passed over oily thick green lake - round the sides the manuka clambered in fantastic blossoming - The air is heavy with sulphur - more steam - white \& fine - Camp by a great sheet of water here the frogs croak dismally - it is a grey evening - Bye \& bye we go to see the mud volcano - meet Maoris - oh, so different - mount these steps - all slimy \& grey \& peer in - It bulges out of the bowl in great dollops of loathsome colour like a boiling filthy sore upon the earth in a little boiling pool below - a thin coating of petroleum - black ridged - Rain began to fall - she is disgusted \& intrigued Coming back the horrible roads the long long distance \& finally - soaking wetness \& [f. 22v] hunger - Bed - \& wetness again - The morning is fine but hot - the nearer they get to the town the more she hates it - perhaps it is smell. It is pretty hot a rise to see the blue lake - They pass Whaka - ugly suburban houses - ugly streets old shaking buses

338 mount] M, G, S, mound MM; 341 Tense] S, Intense MM, M, G; 342 by and bye] G, S, by and by MM, M; 343 Prison] . . MM, [illegible] M, forest G, Forest S; 344 the road pass] G, in the road we pass MM, the road passes M, G, the road pass[es] S; 345 the baked ribbing] the baked [illegible] M, the baked red $\mathrm{G}$, the naked ribbing $S ; \quad 346-7$ passed over oily thick green lake] pass one oily green lake MM, pass one oily bright green lake M, passed one oily bright green lake $\mathrm{G}$, passed over the oily thick green rape S; 350 Bye \& bye] G, S, by and by MM, M; 351 volcano] G, S, volcanos MM, volcanoes M; meet Maoris] marvellous G, S; 353 boiling] G, S, terribly MM, festering M; filthy] M, G, S, grisly MM; 354 boiling] $\mathrm{G}, \mathrm{S}$, whirling $\mathrm{MM}, \mathrm{M} ; \quad$ ridged] $\mathrm{G}, \mathrm{S}$, with jet $\mathrm{MM}$, as jet $\mathrm{M} ; 355$ intrigued] outraged $\mathrm{MM}, \mathrm{M}, \mathrm{G}, \mathrm{S} ; \quad 356$ horrible] G, S, terrible MM, M; 359 blue lake] S Pareheru G;

343 Prison Tree Plantations A seedling nursery had been established at Waiotapu in 1901 where the 'planting programme was undertaken by goodconduct prisoners' (Stafford, 43). By 1907, the scrubby slopes had already been transformed with squares of young larches and belts of evergreen pines (NZH, 12 June 1908, 7)

346 ff. In the top margin of f. 22 appear the words 'in fantastic blossoming'.

347 green lake Scott acknowledged the dubiousness of her reading 'We passed over oily thick green rape', ceding Gordon's argument that rape (brassica napus), as a winter crop, would not be green in November. Scott was convinced that her reading 'nevertheless still looks correct' (S, 142), however I reinstate Murry and Gordon's reading of 'lake', on the basis that in 1907, as today, 'petroleum is present in considerable quantities ... on the surface of the waters' at Waiotapu (EP, 6 June 1903, 1).

360 Whaka An abbreviation for Whakarewarewa that was common in the period.

360 ugly ... Whakarewarewa, thought to be 'highly picturesque' but 'unwholesome', were replaced at the turn of the twentieth century with unattractive European-style housing. In the sulphurous air 'paint peeled or turned black. Nails rusted and gave way and iron roofs were quickly corroded and useless' (Stafford, 117). KM's opinion that the town was unsightly was widely shared, with one journalist decrying it as 'the ugliest of European shanties, the presence of which considerably discounts the natural beauty and novelty of the surroundings' (PBH, 2 September 1904, 4). 
crowds of the veiled tourists - But letters are good $-\&$ they camp in a paddock behind the puffing trains - How nice the old lady is next door $-\&$ her flowers - her white peacotes $\&$ briar roses - that evening she has a bath -

Thursday the loathsome trip -

Friday so tired that she sits in the sanatorium grounds all the morning and that even horrid the people - bores - \& [?Morning T -] Afternoon in Whaka - the geyser good \& the cerise handbags - Also the little naked boys and girls [f. 23] but the coy airs bah! Rain again

Saturday letters - far more $-\&$ lunch with Tom, $\&$ the quiet afternoon - fearful rain - up to the ankles - The wet camp [f. 23v] the fear of having to move - She thinks Rotorua is loathsome \& likes - only that little Hell.

Sunday morning the early start, $\&$ it seems at each mile post her heart leaps - But as they leave it the town is very beautiful - \& Whaka full of white mist - strangely fanciful. She almost wishes - no - oh, it is too hot where they lunch - she feels so ill - so tired - her headache is most violent - she can hardly open her eyes - but must lean back each jolt of the cart pains her - but the further they go - the load begins to lighten - Then meet a Maori again - walking along - barefooted and strong - she shouted Te nokoto - and Kathie's heart [f. 25] is warm again - there is no maudlin affectation -

363 peacotes] piccotes $\mathrm{G}, \mathrm{S} ; \quad \mathbf{3 6 6}$ sanatorium] M, G, S, town MM; 367 people - bores $-\boldsymbol{\&}$ [?Morning $\mathrm{T}$ -]] the purple bowl - I bought G, the people - bores[?] Morning \& S; 367-8 Afternoon in Whaka - the geyser] $†$ presents in Whaka - the [indecipherable word] $\mathrm{G}$, Afternoon in Whaka - the [...] seem S; 372 likes] G, S, ugly MM, M; 373 Hell] M, S, Hill G; 375 Whaka] G, S, Whaha M, MM; 376 no] S, .. M, MM, and G; 381 Te nokoto - and Kathie's heart] 'Tenakoe.' (good day!) ... MM, 'Tenakoe'. M, Te nakohi and Kathie's heart G, Te nakoto \& [...] S; warm] S, train G; $\mathbf{3 8 2}$ maudlin affectation] S, missing this affliction $\mathrm{G}$;

361 letters Elsie Webber recalled that 'K.B. received mail from home, and read me extracts from her letters. I can remember one letter where her sister told her she was very much missed and that her "cello was hiding disconsolately in a corner of the music room' (Webber MS).

363 peacotes picotee, a flower variety where each petal's border is a different colour to its interior. By the time she published 'At the Bay' (1922), KM had adopted the correct spelling: 'Dazzling white the picotees shone' (KO'S, 354).

367 bores C.K. Stead has proposed that this word reads 'bowls', an interpretation he felt was justified because 'there was, even in 1907, a bowling green in those Rotorua gardens, and since people playing bowls are the kind the young Mansfield would very likely describe as 'horrid' (Stead, 221).

370 Tom Thomas Edward Youd Seddon (18841972), son of New Zealand's late Prime Minister Richard Seddon, was related to KM by marriage. His sister Phoebe had married KM's maternal uncle, Frank Dyer. Seddon recalled meeting KM in Rotorua where she was 'sitting on a bench under some willows in the drizzling rain, and looking very despondent' (Scott MS).

373 Hell Gordon considered Murry's transcription of 'Hell' to be a misreading of 'strategic importance in the narrative' which fostered 'the conception of KM as an unhappy young woman on her return to New Zealand' (19). He emphasised that KM 'enjoyed Rotorua's 'little Hill'. This seems partisan since it is almost impossible to determine whether KM wrote 'Hell or 'Hill': as Scott noted, 'the word itself could be either; one's reading of it depends on the sense'. Scott considered 'Hell' to be more likely, and a reference to 'the boiling mud so feelingly described in the preceding paragraph' $(\mathrm{S}$, 143). The absence of any dot signifying a letter ' $i$ ' and the fact that the nearby geothermal region of Tikitere was commonly known as 'Hell's Gate' (Ell, 26), likewise favour 'Hell' as the more likely reading. 381 Te nokoto Ma. 'Tena Koutou', a greeting said to three or more people. 
[f. 21] Thursday - on the lake - A beautiful day - the people - Rotorua is not what I expect.

Friday - A quiet day in the grounds - raining - [two words illegible]

afternoon - baths - Priest \& Rachael - Felt fearfully low -

Saturday Rain - letters - [?Tom] Hotel - rain - bad night -

Sunday leave - fine day.

[f. 23] Rotorua

Friday

Mother dearest -

Thank you for your wire which I received today and for

Chaddie's lovely letter So Vera has definitely gone I can hardly realise it - What a strange household you must be feeling -

As to me: - I have been bathing twice a day - the Rachael and the Priest Baths they are delightful, but they take it out of you to a very

[f. 24] Rotorua -

Friday

Mother dearest

Thank you for your wire which I received today and for

Chaddie's lovely letter - So Vera has definitely left, I can hardly realise it - What a strange household you must be feeling -

You sound most gay at home - I am so glad -

I wrote to Chaddie on Wednesday Yesterday was very hot indeed A party of us went a Round Trip to the Hamurana Spring - the Okere Falls across Lake Rotoitii, to Tikitere, and then back here by coach - I confess, frankly that I hate going trips with a party of [f. 24v] tourists - they spoil half my pleasure - don't they yours? You know one lady who is the wit of the day and is 'flirty', and the inevitable old man who becomes disgusted with everything, and the honey moon couples - Rotorua is a happy hunting ground for these - We came back in the evening grey with dust - hair and eyes and clothing, so I went and soaked in the Rachael bath - The tub is very large - it is a wise plan to always use the public one - and there one meets one sex very much "in their nakeds" - Women are so apt to become communicate on these occasions that I [f. 25] carefully avoid them - I came home, dined, and went into town with $\mathrm{M}^{\mathrm{rs}}$ Ebbett We ended with a Priest Bath - another pleasant thing, but most

385 A quiet] S, We spent G; [two words illegible]] bathing and walked G, reading \& watched[?] S; 387 [?Tom]] the G, Tom's S; bad] S, and at G; 404 Okere] S, Ottere MM; Ohere G; Rotoitii] Rotoiti MM, G, S; 415 Ebbett] G, S, Ibbett MM;

\begin{abstract}
389-95 Rotorua ... a very This draft letter is deleted by means of a single swirling strike-though. 392 Vera has definitely gone KM's eldest sister was staying in Sydney with relatives of KM's paternal great-aunt Elizabeth (Louey) Weiss Beauchamp, née Lassetter. She had been sent 'as a distraction' from James Macintosh Bell, the man she later married (O’SS, 33-4).
\end{abstract}

394-5 Rachael and the Priest Baths Two springs near the Rotorua Sanatorium. Used by Maori for centuries, Te Pupunitanga was renamed the Priest's Bath when Father Mahoney of Tauranga cured his rheumatism after bathing there in 1878 (CNZ, 801). Whangapipiro was renamed the Rachel Pool for the English cosmetician Madam Rachel, because of the benefits of silica water on the skin. 
curious - At first one feels attacked by by Deepa's friends - the humble worms - The bath is of aerated water, very hot, and you sit in the spring - But afterwards you

[f. 26] Sunday -

Nowhere.

420

Dear Mr Millar -

I have to thank you for keeping my none too small amount of correspondence - I went to the Bank yesterday afternoon - foolishly forgetting that it was closing day. Would you kindly address any letters that may arrive for me c/o Bank of New Zealand - Hastings - I shall be there on Saturday -

This paper is vile, but I am once more on the march,

Once more thank you -

Sincerely yours

K.M. Beauchamp

[f. 27] Sunday.

I am tired to death with a headache, \& a thoroughly weary feeling

The stones [illegible] blue hills. The great basins the birds - the wonderful green flax swamp, and always these briars - Mist over the distant hills - the fascinating valleys of toi toi swayed by the wind. Silence again, and a wind full of the loneliness and the sweetness of the wild Places - Kathie in the morning in the manuka paddock saw the dew hanging from the blossoms - \& leaves - put it to her lips $\&$ it seemed to poisen her with the longing for the sweet wildness of the plains - for [f. 27v] the silent speech of the Silent Places - the golden sea of tussock ${ }^{\wedge}$ Rotorua $^{\wedge}$ The first evening - the yellow sky - she lies in the grass tired $-\&$ hears the $X$ bell - It sounds across the darkness - ineffably tender and touching like the touch of a child's hand in the dark -

The Hamurana Spring the still rain - the colour - the tangle of willow $\&$ rose $\&$ thorn - like Millais' Ophelia the undergrowth $-\&$ then the spring - like Maurice Maeterlinck -

417 by by] by MM, S, by by by G; 421 Millar] G, S, Miller MM; 424 Would] G, S, Will MM; 427 march] G, S, ranch MM; 428 thank] G, S, thanking MM; 433 The] Like G, S; [illegible] blue] bright bare G, grey \& blue S; birds] S, hills G; 434 Mist over] S, bush on G; 436 wind] G, world S; 439 poisen] poison $\mathrm{G}, \mathrm{S} ; \quad \mathbf{4 4 1}$ sea] $\mathrm{G}$, rain $\mathrm{S} ; \quad$ tussock] blossom, G S; 443 ineffably] S, beautifully G; 445 colour - the] wonderful G, colourful S;

417 Deepa's friends 'Deepa' was KM's paternal great-uncle Henry Herron Beauchamp, with whom she had stayed with in England periodically during 19031906. A keen agriculturalist, Henry Beauchamp 'delighted in growing things' (de Charms, 53).

421 Mr Millar R.B.T. Miller was the Manager of the Rotorua branch of the Bank of New Zealand.

431 ff. [f. 26v blank]

$442 \mathrm{X}$ A symbol for 'Christ' or 'Christian', from the Greek letter 'khi' (X), but probably intended by
Mansfield to mean 'Church'.

446 Ophelia An oil painting by Sir John Everett Millais (1829-1896) depicting the death of Ophelia, a scene described in Shakespeare's Hamlet. KM had possibly seen the work at the Tate Gallery in London where it had been displayed since 1897 .

447 Maurice Maeter linck In his symbolist play Palléas and Mélisande (1892), Belgian playwright Maurice Maeterlinck (1862-1949) introduces the heroine, Mélisande, weeping by a clear forest spring. 
Monday. All Sunday the further she went from Rotorua the happier she became - Towards evening - they came to a great mountain Pohataroa - it was very rugged \& old \& grim - an [f. 28] ancient fighting pah - Here the Maoris had fought - and at the top of this peak - a spring bubbled - In the blue evening it was grim, forbidden silent - towering against the sky - an everlasting monument - Then rounding a corner they saw the Waikato river - turbulent muddy rushing below them $-\&$ in a little hollow - girt about with pine $\&$ willow tree the Atiamuri Hotel - As they neared the house the persistent barking of dogs - the people hanging over the fence - the old sedately - ridiculous turkeys - They camp - in a paddock by the river a wonderful spot - On the side of the river on the opposite bank - great scrub covered mountains - Before [f. 28v] them a wide sheet of swift smooth water - and a poplar tree $-\&$ a long straight guerdon of pines - The willow tree - shaggy and laden dips lazily luxuriously in the water - Just upon the bank ahead of them a manuka tree in full flowers leans toward the water - The paddock is full of manuka - two grey horses are outlined against the sky After dinner - they are [?hungry] \& tired - the man comes from the hotel - Yes there are rapids to be seen - and a ford track - They are not very far - he is gloomy and fidgety - they start - go through the gates - always there is a thundering sound from afar off - down the sandy path $-\&$ then branch [f. 29] off into a little pine avenue - the ground is red brown with needles - great boulders come in their path - the manuka has grown over the path - with head bent - hands out - they battle through - Then suddenly a clearing of burnt manuka and they both cry aloud - There is the river - savage grey - fierce rushing tumbling - madly sucking the life from the still placid flow of water behind - like waves of the sea - like fierce wolves - the noise is like thunder $-\&$ right before them the lonely mountain outlined against a vivid orange sky. The colour is so intense that it is reflected in their faces in [f. 29v] their hair - the very rock on which they climb is hot with the colour - They climb higher - the sunset changes - becomes mauve $-\&$ in the waning light all the stretch of burnt manuka is like a thin mauve mist around them. A bird - large and widely silent - flies from the river right into the flowering sky There is no other sound except the voice of the passionate river They climb onto a great black rock \& sit huddled up there - alone -

448 Rotorua] MM, G, S, Rotarua M; 452 peak] MM, G, S, pah M; 454 Waikato] M, G, S, Wairakei MM; muddy] S, and wildly MM, M, madly G; 458 old] G, red S; 462 guerdon] line MM, M, † guardian G, guerdon [sic] S; 463 luxuriously] S, branches G; 464 flowers] G, S, blossom M, MM; 466 [?hungry] hungry G, happy S; 468 he] S, she G; 470 avenue] M, G, S, cavern MM; 471 ground] M, G, S, floor MM; 474 both] MM, M, G, [...] S; 475 madly] M, G, whirling MM, thrashing[?] S; sucking] M, G, S, suddenly MM; 477 lonely] M, G, S, lovely MM;

450-1 Pohataroa ... ancient fighting pah The 500-foot high rock near the Waikato River had been a final stronghold of Ngati Kahupungapunga against the invading Ngati Raukawa (Wai 33, 32). 462 guerdon n. reward (chiefly archaic). KM's use of the word appears inapposite. 
fiercely almost brutally thinking - like Wagner Behind them - the sky was faintly heliotrope \& then suddenly from behind a cloud a [f. 30] little silver moon - shone through one sudden exquisite note in the night terza The sky changed - glowed again, and the river sounded more thundering - more deafening They walked back slowly - lost the way - and found it - took up a handful of pine needles $-\&$ smelt it - greedily $-\&$ then in the distant paddock - the tent shone like a golden poppy - washing outside the stars $-\&$ the utter spell - magic

Next morning - mist over the whole world - Lying - her arms over her head - she can see - faintly like a grey thought the river \& the mist - they are hardly distinct she is not tired now only happy - Goes to the door of the tent $-[\mathbf{f} . \mathbf{3 0 v}]$ all is very grey - there is no sun first thing - she can see the poplar tree mirrored in the water - The grass is wet - there is the familiar sound of buckets - As she brushes her hair a wave of cold air strikes her - lays cold fingers about her heart it is the wizard London - Gradually the sun comes - the poplar is green now - the dew shines on everything - a little flock of geese and gosling - float across the river - the mist becomes white - rises - from the mountain ahead - there are the pines $-\&$ there, just on the bank the flowering manuka is a riot of white colour against the blue water - a lark sings - the water [f. 31] bubbles - she can just see, ahead the gleam of the rapids - The mist seems rising \& falling here comes the theme again for the last time $-\&$ now the day fully enters with a duet for two oboes - you hear it - Sunshine had there ever been such sunshine - they walked down the wet road - through the pine trees the sun gleamed golden - locusts crunched in the bushes - through her thin blouse she felt it scorching her skin and was glad -

Monday on the road to Orakei - Koraka - The rainbow Falls in a great basin - We [?surmount] the hills - at the summit we look

486 Wagner] G, S, Wapi MM, M; 493 washing] S, waiting G; 495 Next morning] S, mist moving MM, M; $\quad$ Mist moving G; 496 river] G, S, moon MM, M; 497 distinct] G, S, distinguishable MM, M; 500 familiar] G, S, faintest MM, M; buckets] S, crickets MM, M, G; brushes] M, G, S, touches MM; 501 lays] G, Damp MM, damp M, clamps S; 502 wizard London - Gradually] shadow from Pohataroa G, wizard London. Gradually S; $\mathbf{5 0 3}$ now] M, G, brown S; the dew] G, S, The dew M, Oh, it MM; flock] M, G, grove MM, group S; $\quad$ geese] M, G, S, forest MM; 504 becomes] MM, M, S, feather G; 506 manuka] G, S, manuka M, bank MM; riot] G, S, moat MM, mass M; 509 the theme] S, that heron G; 512 crunched] M, G, S, cornered MM; 513 it scorching her skin] M, G, S, its scorching touch MM; 515 Koraka] S, Korako G; 516 [?surmount]] mount G, surmount[?] S;

486 Wagner A reference to the opera cycle Der Ring des Nibelungen by Richard Wagner (18131883 ) in which three water nymphs are charged with protecting gold in the rocky depths of the Rhine.

489 terza It.. 'Third'. A musical term signifying a three-pitch interval in a scale.

500 buckets Presumably the metal washing tubs pictured in image 15 .

502 wizard London Scott deciphered this phrase by comparing it with the lines 'The wizard has his way / And London's ever calling me' (S, 86) in KM's 1907 poem 'And London is calling me the live long day'. $\mathbf{5 0 7} \mathbf{f f}$ In the top margin of f. 31, appear the words 'orakei Koraka' 
below at mile on mile [f. 31v] of brown river - winding in and out among the mountains - the bank - fringed with toi-toi - All the plains \& hills are like a mirror for the sky - we $3 \mathrm{climb}$ to a great height. Then there came rapids - great foaming rushing torrents they tore down among the mountains - thundering - roaring - We drew rein $-\&$ there was a wide space of blue forget-me-nots -

[f. 31v] The quiet bush - sunshine on the golden moss - The silent river - the ducks, the mint - the quiet $\&$ then through the leaves $\&$ trees - the water. Then the climb - the rocks - the uncertain foot walk - higher and higher - clinging to the trees - the shrubs till at last - on the [f. 32] grey rock we fling ourselves - blue as the tropical sea where the rapids commence $-\&$ then a tumultuous - foaming torrent of water - leaping crashing, snow white - like lions fighting - thundering against the green land $-\&$ the land stretches out ineffectual arms to hold it back - It seems there is nothing in the world but this shattering sound of water - it casts into the air a shower of silver spray - it is one gigantic battle - I watch it and am one with it. [f. 32v] Then through more bush - the ferns are almost too exquisite - gloomy shades - sequestered deeps $-\&$ out again another rock to climb - another view - here the colouring is far more intense the purple the blue - the great green lashed rock - the water thunders down foam rushes - then pours itself through a narrow passage $-\&$ comes out in a wide blue bay - Also floating on the water are the canoe remains - more rushing white $\&$ wider passage - more eddy $-\&$ at last - far in the distance - a wide shining stretch of shadowed sweetness - Peace We plunge back again - there is a last view - very near the water - the sound is far louder \& under it all I hear the dull [f. 33] booming sound - it rises half a tone about each minute but that is all - it never ceases $---\&$ where the water catches the light - there is a rainbow pink, blue and white - But it is all too short -

517 below] S, down G; 518 bank - fringed] banks quivered G, banks fringed S; $\mathbf{5 1 9}$ \& hills] S, for miles G; 523 sunshine on] and mist is on $G, \&$ mist is in $S ; \quad 524$ mint] S, mist G; 528 then a tumultuous] G, $\mathrm{S}$, there is the sea MM; $\mathbf{5 3 2}$ into the air] G, S, a thousand MM; $\mathbf{5 3 4}$ one with it] S, am thrilled M, G; 537 lashed] G, S, clad MM; 540 canoe remains] [two words indecipherable] G, canoe[?] remains S; $541-2$ a wide ... shadowed sweetness] $S$, stretching shadowed steadiness $M M$, a wide strong stretch of shadowed sweetness G; 543 sound is] G, S, mountains MM; 543 louder] G, S, distant MM; 544 dull] S, falls G; sound] G, S, wind MM; about] G, S, above MM; 545 where] S, when G; 546 and] S, amber MM; it] S, time G;

527 ff. In the top margin of f. 32 appear the words 'Ara tia tia Rapids' and 'the almost purple'. On the first eight lines, there also appears a clothing list:

1 nightdress

3 petticoat bodices

2pr. drawers, dress shields handkerchiefs $\begin{array}{ll}2 \text { pr. } & \text { stockings } \\ 3 & \text { vests } \\ 2 & \text { blouses - }\end{array}$

540 canoe remains Midway up the Aratiatia Rapids there was in 1907 'a collection of timber wheeling round in the maelstrom', the remnants of a canoe that 'got adrift and came over the rapids' and was seen 'from time to time, gradually getting smaller' (AS, 2 January 1907, 9). 
[f. 33]

Dear Man -

I am a vagrant - - a Wanderer, a Gypsy tonight
Monday Night

550

Monday Night

\section{[f. 34] In Bed \\ Dearest Baby -}

This will, I think be my last letter to you - before I reach home - I wrote last to Chaddie from Rotorua - I must say I hated that town - it did not suit me at all - I never felt so ill or depressed It was, I

[f. 33] Orakei-korako Round a bend of the road \& the river - we see poplars - tall \& strong, and a suggestion of a fence - Then more poplars $-\&$ then in the distant - a great patch of flowering potatoes - mauve, [f. 33v] blue \& white - There is no sign of people - not the sound of a dog - but we hear from among the manuka - the deathlike thudding - like a paddle wheel - We go down to the dragon's Mouth - it is a most difficult walk - down a scrambling path - holding on by bushes and trees - then there is one fierce jump \& we are there. It belches filthy steam and smoke - there is green slime - and yellow scale like appearance - infinitely impressive - and, always that curious thudding engine like sound. We walk on a broad flat terrace $\&$ there is so thin a crust that one would thought it almost dangerous to move - we see a very small geyser in the river $\&$ mud $\&$ sulphur holes - Across the [f. 34] road \& in the manuka is a pink mud pool. The other side of the river are many steam holes $-\&$ signs where geysers have been - And signs where terraces might be - it is too brazenly hot for words - we hear the whole time the noise -

\section{0}

565

570 $\mathbf{5 4 9}$ Man] S, Marie G; $\quad \mathbf{5 5 6} \mathrm{I}] \mathrm{G}, \mathrm{S}, \mathrm{H}-\mathrm{MM}$; $\quad \mathbf{5 6 7}$ curious] S, ominous MM, terrible G; $\quad \mathbf{5 6 9}$ in the
river \& mud \&] S, and view the MM, and the rock and mud and G;

\begin{abstract}
549 Dear Man Gordon read 'Man' as 'Marie' and suggested this was a letter written to Chaddie Beauchamp. O'Sullivan and Scott read 'Man' and suggested the letter was intended for Thomas Trowell, the young violoncellist then studying in Europe for whom KM had a teenage infatuation. However, all editors have assumed that the letter encompassed more of the text on f. 33 that it actually does: KM's description of the thunderous sounds of the Aratiatia Rapids belongs to a separate entry (see 11. 553-6) but prior editors have considered it a continuation of the draft letter to 'Man'. O'Sullivan and Scott saw KM's 'musical allusions' (CL, 35) in her depiction of the Aratiatia Rapids as evidence that the letter was intended for Trowell, but since these 'musical allusions' belong to another entry, the identity of 'Man' remains mysterious.
\end{abstract}

551 In Bed This letter heading is accompanied by a doodle of a three dimensional cube and a flower. 552 Baby Jeanne Worthington Beauchamp (1892-1989) was KM's youngest sister.

557 Orakei-korako This is an inaccurate heading for the following description. The distinctive geysers that KM describes in 1. 562 were at Wairakei. 560 ff. Across the top margin of f. 33v appear the words 'Leslie Heron Beauchamp'. This is the full name of KM's only brother.

562 paddle wheel One of the Wairakei geysers was known as 'Paddle-wheel Ben' due to the throbbing noises it emitted resembling 'a paddle wheel of an immense steamer' (AS, 2 January 1907, 9).

562 dragon's Mouth Another geyser, so called because the rock at its point of discharge was thought to resemble the gaping throat and jaws of a dragon. 
[f. 34v] Tuesday - We drove through Weiraki through the hot day to the Huka (huga Falls) here the river is the colour [illegible] ${ }^{\wedge}$ peacock ${ }^{\wedge}$

[?blue] - the falls utterly superb - frothing and foaming - the foam drops for a long way down the water - again the sound two great poplars at the side - in the distance the gleaming river - But I was not so impressed at first sight. We drove into the bush - then got on to a bridge - stood there - and went [?silent] - all the shuddering wonder was below us! In the afternoon we climbed down the bank first a ladder then rough steps - another ladder - catching swaying laughing bush to one side - and a fern grotto - pale green - like Tannhauser green ferns - hang from the top all round us - dampness \& beauty and we are below [f. 35] the falls - the mountain of water the sound the essence of it - a peculiar green So we drove -

[f. 36] We come over the hill to Taupo - Before us the lake - - in the foreground blue, then purple then silver - On this side the pines - the gum trees - the clustering houses - and a fringed yellow meadow - In the istan lake the little Motetaika - and beyond that silver water mountains - until at last Ruapehu snow covered majestic - God of it all - towers against the sweet sky - already behind us Tohara is under a cloud all the clouds are so vivid white - grey blue - On one side there is a little jutting promontory of free flat land - In the track the broom - We approach Taupo - across a white bridge - the peacock blue river along a white road - to the Lake Hotel - there are the [f. 36v] Maoris lounging in the sun one

574 drove] S, drive G; Weiraki] G, Wairakei S; $\mathbf{5 7 5}$ huga] high G, [...] S; [illegible]] turquoise G, S; $\mathbf{5 8 0}$ went] G, were S; [?silent]] quiet G, silent[?] S; $\mathbf{5 8 4}$ ferns - hang] G, S, fern leaf MM; $\mathbf{5 9 1}$ Motetaika] Motutaiko G, S; 592 silver] S, clear G; $\mathbf{5 9 3}$ God] S, Lord G; 592 sweet] steel G, S; already] S, clearly G; $\mathbf{5 9 5}$ track] $\dagger$ track G, bracken S;

\begin{abstract}
581-2 we climbed ... ladder Gordon described the ladder-climb beside the Huka Falls as a 'perilous expedition (long abandoned as a tourist attraction)' which 'KM simply took in her stride. Her stamina as a young woman runs counter to the popular notion of her' (79). Gordon corroborated this interpretation by quoting from the outdated Hand-book for Travellers in New Zealand (1893), which said of the ladders: 'The descent is difficult, and the return much more so. None should attempt it without a guide' (34). In fact Gordon overstated KM's boldness: by 1907 the descent by ladder was publicised as a 'must-do' experience and the means of getting 'the best idea of the magnitude of the Fall' (AS, 2 January 1907, 9).
\end{abstract}

584 Tannhauser The first act of Wagner's 1845 opera Tannhäuser und der Sängerkrieg auf Wartburg takes place in the Venusberg, a mythical German mountain with subterranean caverns where Venus held her court.

588 ff. In the middle of f. $35 \mathrm{v}$, which is otherwise blank, appear the translations:

-Wai-otapu

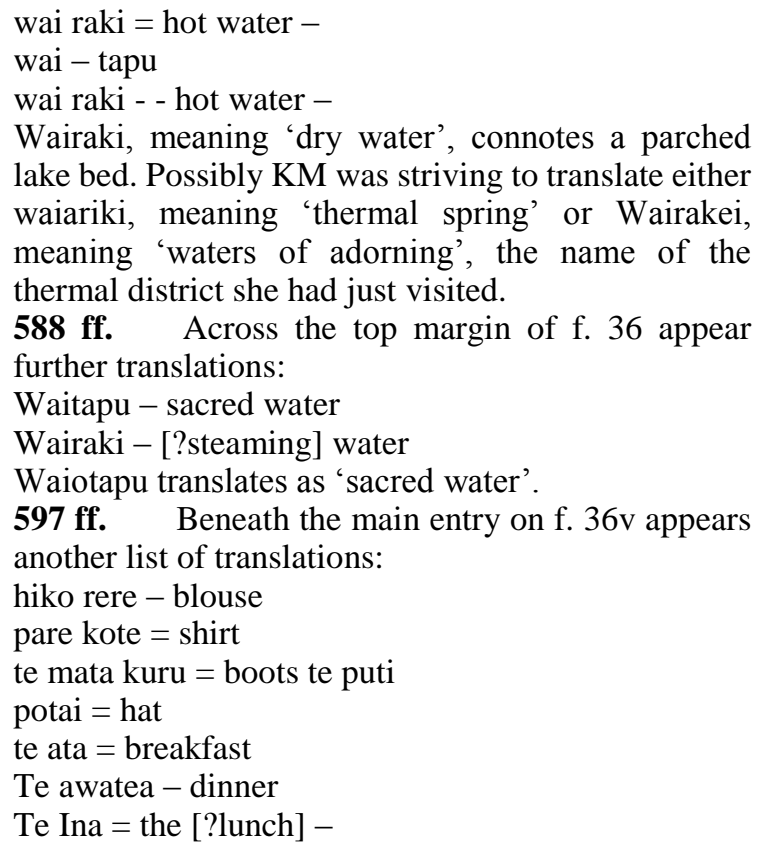


in a black \& white blazer - blue pants - In the shade an old Maori drunk - \& a little child is crouched - soon other Maoris come out help the old man into a ramshackle cart where a white boney horse is very lamed - The child cries \& cries - the old man sways to and fro - she holds on to him with a most pathetic gesture. They drive out of sight -

$\underline{\text { Vignette }}$

Sunset Tuesday

I stand in the manuka scrub - the fairy blossom - Away ahead the pines - black, the soughing of the wind - On my right the lake is cold, grey, steel like the quiet land sleeps beside it away ahead - in the silver sea lies the island - Then the wild sky - everywhere the golden broom tossed its golden fragrant plumes into the evening air - I am on a little rise - to my right a great tree of mimosa laden with blossoms - bends \& foams in the breeze - And, before me, the lake is drowned in the sunset - The distant mountains are silver blue - and the sky - first vivid rose - thin \& spreads into a pale brown colour amber - [f. 37v] Far away on my left the land is heavily heliotrope curving \& sharply outlined - and fold upon fold of grey sky And - far far ahead - in the blue sky - a silver ^little golden^ ${ }^{\wedge}$ moon - daintily - graciously dances in the blue floor of the sky -

A white moth flutters past me - I hear always the whispering of the water -

\section{0}

I am alone - I am hidden - Life seems to have passed away - drifted - drifted - miles \& worlds on beyond this fairy sight -

Very faint $\&$ clear - the bird calls - \& cries - and another in a little scarlet touched pine tree - close by me - answers - with an [f. 38] exstasy of song -

Then I hear steps eoming ^approaching ${ }^{\wedge}-$ A young Maori girl climbs slowly up the hill - she does not see me - I do not move She reaches a little knoll - and suddenly sits down - native fashion - her legs crossed her under her hands clasped in her lap - She is dressed in a blue skirt \& white soft blouse - Round her neck is a piece of twisted flax \& and a long piece of greenstone - is suspended from it - Her black hair is twisted softly at the neck - she wears long white $\&$ red bone earrings. She is very young - she has [five illegible words deleted] [f. 38v] She sits - silent - utterly motionless - her

600 man] G, S, woman MM; 603 out of sight] G, S, into the night MM; 614 vivid] S, faint MM, $\dagger$ turns G; thin \&] S, then MM, G; spreads] G, S, shaded MM; 615 heliotrope] shadowed MM; 616 sky] G, S, cloud MM; 619 whispering] G, S, whisper MM; 625 exstasy] ecstasy MM, G, S; 629 her under] [under her] G, under her S, MM; 631 and] around $\mathrm{G}$, and [sic] S; 633 she has [five illegible words deleted]] ... MM, she has $\mathrm{G}$, whole phrase om. S;

KM was probably striving for the following translations: hikurere - shawl; panekoti - skirt; putu - boots; potae - hat; te ata - morning; te awatea - broad daylight; tina, a transliteration of 'dinner' (the meal eaten at lunchtime).

The intended meaning of 'te mata kuru' is puzzling. 
head thrown back - All the lines of her face are passionate violent

- crudely savage - but in her lifted eyes slumbers a tragic illimitable Peace -

The sky changes - softens - the lake is all grey mist - the land is heavy shadow - silence broods among the trees - the birds are silent now - The girl does not move - But ahead far far away -very faint $\&$ [illegible word crossed out ${ }^{\wedge}$ sweet $^{\wedge}$ and beautiful - a star wakes in the sky -

She is the ${ }^{\wedge}$ very^ incarnation of evening - and lo - the [f. 39] first star - shines in her eyes.

Taupo 10 .

The road winds by the lake - then we mount through great avenues of pines \& acacias - to the Terraces Hotel - Here are lawns and cut trees - little corners long hidden walks - shady paths - all the red-brown pine needle carpet - the house is not pretty but poppies grow round it - All is harmonious \& peaceful \& delicious - We camp in - a pine forest - beautiful - there are chickens - cheeping - the people are so utterly benevolent - We are like children here with happiness - We dine - then the sunset - then supper at the Hotel - and the night is [f. 39v] utterly perfect - We go to the mineral baths - the walk there down the hill - is divine - the suggestion of running water - and cypresses - it is very steep - And a fine bath - though very hot \& a douche - so pleasant - Then home tired - hot - happy - blissfully happy - We sleep - in the tent - the wind is our lullaby -

We wake early - and wash and dress - \& go down to the bath again Honeysuckle - roses pink \& white - periwinkles syringas - red hot pokers - those yellow flowers - the ground is smothered - Fruit trees with promise of harvest - the hot lake \& pools - even - the homely clothes prop in the lush grass $-\&$ more [f. 40] mimosa - - The birds are magical - I feel I cannot leave but pluck the honeysuckle \& the splashes of light lie in the pine wood - Then good bye Taupo and here are more plains I feel quite at home again $-\&$ at last we come to Opipi - the scene of a most horrible massacre - only 2 men were saved- one rushed through the bush - one was cutting wood - We stop to look for water and there are 2 men - one [illegible] one most

635 thrown] MM, S, thrust G: 638 softens] MM, S, after G; lake] S, world MM, calm G; land is] island in $\mathrm{G}$, land in MM, S; 639 broods among the trees] G, S, in the woods MM, 641 wakes] MM, S, twinkles G; 653 dine - then] G, S, drive through MM; 656 And a fine] G, S, not a fire MM; 659 down to] MM, S, into G; bath] G, S, hotel MM; 661 smothered] S, sunflecked G; 666 here are more] G, S, we are on MM; 667 Opipi] G, S, Waihi MM; 669 one [illegible] one] one Oscar, one MM, the older the G, one seems the $\mathrm{S}$;

667-8 Opipi ... cutting wood The constabulary camp at Opepe was the site of an 1869 'controlled military operation' $(R S, 167)$ in which followers of Te Kooti sprang a surprise attack on the armed cavalry encamped there. Nine constabulary-men were shot and five escaped through nearby bush. Historical newspaper reports and modern histories make no reference to any survivor 'cutting wood'. 
perfect Maori - like bronze the new pink shirt printed images - his

horrible licensed walk his cigaret - Then we are in a valley of broom - such colour - it is strewn everywhere - [f. 40v] I have never dreamed of such vivid blossom - then lunch at Rangateiki, the store is so noisy - they do not seem glad or surprised to see us - give us fresh bread, all seems so familiar and they seem [?troubled] And afar the plain - We say goodbye to [illegible] - and at night fall rounding the road, reach our copse. It is a threatening evening - the farm child - the woman her great boots - she has been digging - How glad she is to see us - her garrulous ways and the child's thoughtful fascination Then at night among the tussocks Then the pumice hills - river - and rain pours -

[f. 41] Wound in [illegible] tarpaulin like a kitten - sheltering [?young thing] in wet clothes - bathing face $\&$ neck $\&$ hands in a bucket of water Then in the full glory of the morning - the dew on the grass \& manuka - a lark thrilling madly - drinking a great pannikin of tea and a whole round of bread and jam -

December 14th My last morning - Oh! what a storm last night - and a crimson dawn - with the willows lashing together -

the [?lilies]

[f. 41v] Youth

O Flower of youth!

See in my hand I hold

This blossom flaming yellow \& pale gold -

And all its petals seatt flutter at my feet

Can Death be sweet?

670 bronze] S, iron MM, image G; new] S, other G; printed images] pink eyes G, printed images[?] S; 671 licensed walk] S, beard rolls G; broom] G, S, colour MM; 673 such vivid] S, so much MM, G; Rangataiki] S, Rangitaiki G; 674 noisy] ugly G, S; 675 seems] surly G, S; $\quad$ [?troubled]] troubled G, troubled[?] S; afar] again G, S; $\quad 676$ illegible $]] \dagger$ Rangitaiki G, [... S; 676-7 rounding the road] coming the way $G$, rounding the bend $S ; \quad 677$ copse] S, camp G; $\quad 680$ pumice hills] Waipunga falls G, S; 681 pours] S, follows G; 682-3 Wound in [illegible] tarpaulin like a kitten - sheltering - [?young thing] in wet clothes - bathing] found a cover tarpaulin here a better shelter - you fling on your clothes - bathe G, Wound in a rolled[?] tarpaulin like a kitten, sheltering, young thing in wet clothes, bathing S; $\mathbf{6 8 3}$ hands] S, back G; 685 manuka] S, warrata G; $\quad 687$ My last morning] S, the last night G; 688 crimson] S, coming of G; 689 [?lilies]] hollies[?] S; om. G;

671 valley of broom This scene was inspiration for the poem 'In the Rangitaiki Valley' (1909).

677-8 farm child ... woman Helen Himing (unknown-1938) was the wife of Ernest Arthur Yates Himing (1869-1955), the roadman who tended a lengthy stretch of the Napier-Taupo Road. Their daughter, Francis Ella, was five years old in 1907. Elsie Webber recalled reaching Runanga, where 'at a very lonely isolated spot, we saw a cottage. We knocked at the door as we wished to get permission to pitch our tent on the property. The door was opened by a cheerful blowsy woman, who proved to be the roadman's wife. Delighted to find a crowd of humans to talk to she cried, "Come in and sit down. I'll make a cup of tea. I haven't got me drorin' room boots on!" This remark tickled K.B. immensely. I feel very sure that this meeting with the roadman's wife was something she never forgot and many years later gave her the inspiration for The Woman at the Store.' (Webber Papers). 
Look at it now!

Just the pale stem is heart -

Heart of the flower see is - white \& bare

The silken wrapping scattered on the ground

What have I found?

If one had come

On a sweet summer day

Breathless, half waking - full of youth I say

If one had come as mist [illegible] from the glen

What happens then?

[f. 42] Sighing it dies

In the dawn flush of life

Never to know the terror \& the strife

Which kills all summer blossoms when they blow

$\left\{\begin{array}{l}\text { Far better so! } \\ \text { Ah! better better so }\end{array}\right\}$ !

K. Mansfield

December 15th 1907.

Baby

Albert Mallinson

send for my camera -

715

Timetable -

6-8 technique

9-1 practise

2-5 write -

Freedom

[f. 42v] In the train - December 17th Has there ever been a hotter day - The land is parched - golden with the heat - The sheep are sheltering in the shadow of the rocks - in the distance the hills are shimmering in the heat $-M$. and I sitting opposite each other - I look perfectly charming.

And I read a little book called The Book of Tea - it is wholly adorable

697 stem] green G, gleam S; 698 see is] S, seems G; 704 as mist [illegible] from the glen] it G, If one had come $[. .$.$] from the glen S ; \quad 722$ is parched] $G, S$, parches MM, parched M; 723 rocks] M, G, S, (woods) $\mathrm{MM}$,

714 Baby Jeanne Beauchamp (see 1. 552). 714 Albert Mallinson English composer Albert Mallinson (1870-1946) was due to give a series of concerts in New Zealand in 1908, an 'anticipated tour' that was already being advertised in newspapers by 1907 (PBH, 13 June 1908, 2).
724 M. Millie Parker.

726 The Book of Tea Written in 1906 by Okakura Kazuko, curator of Eastern Art at Boston Museum, The Book of Tea was a popular etiquette guide and philosophical treatise on the Japanese art of tea-making. 
[f. 81v] en oho ha ${ }^{\wedge} \mathrm{ra}^{\wedge}=$ good bye to you who are staying -

tamaiti $=$ child -

tangata man

e ta haeremai te kai $=$ I say come to eat

en ohora $=$ good bye to you (staying)

Haere $\mathrm{ra}=$ goodbye to you (leaving)

tamaiti $=$ child ta mariki

tangata $=$ man -

raupo $=$ flax

In this part of the island "wh" is "f".

Te whaiti - Te f a i t i -

[?cuoa] $=\mathrm{k} \mathrm{u} \mathrm{i} \mathrm{f} \mathrm{a} \mathrm{=} \mathrm{where} \mathrm{but} \mathrm{why} \mathrm{does} \mathrm{that} \mathrm{hold} \mathrm{[several} \mathrm{illegible}$

words crossed out $]^{\wedge}$ that's right ${ }^{\wedge}$

Hau-Hau paimarere $=$ peace $\&$ goodwill

pipi whar $^{\wedge} \mathrm{ur}^{\wedge} \mathrm{Oa}=$

pipi wharuroa - a bird of good tidings - and good news. size of a

skylark - it has a green striped head -

[f. 82] te hoi ho $=$ horse

te hipi $=$ sheep

te rori $=$ the road -

[illegible $][$ ai ke ki $]=[$ illegible $]$

korero pakeha i akoi - do you speak English -

kapai te wera - hot day

te rangi pai $=$ fine day

taha $=[$ illegible $]$

rewi $=$ potato -

728 en oho ha ${ }^{\wedge}$ ra $\left.^{\wedge}\right]$ enohora $\mathrm{G} ; \quad 752$ taha $=[$ illegible $\left.]\right]$ kaha - strong G; 753 rewi] riwai;

728-53 en oho ... potato Scott reproduced Gordon's transcription of these translation lists deeming the originals 'no longer adequately legible' having been 'pored over too often' (166). KM was probably striving for the following translations (repeated words omitted):

e noho ra - goodbye (said to someone staying)

tamaiti - child

tangata - man or people

haere ra - goodbye (said to someone leaving)

tamariki - children

raupo - reeds

kei whea? - where?

te hoiho - horse

te hipi - sheep

te rori - road

Korero Pakeha koe? - Do you speak English?'

kapai te wera - lit. the heat is good

te rangi pai - lit. the good day taha - side, calabash or gourd

riwai - potato

731 e ta haeremai te kai 'e ta, haeremai ki te kai' is an invitation to partake in food. The words ' $\mathrm{E}$ ta', which KM translated as 'I say', and Gordon and Scott both translated as 'friend', is primarily an expression emphasising the call to eat. In spoken Maori, the particle 'ki' may have been dropped.

741 Hau-Hau paimarere Pai Marire, the syncretic religious movement developed by Te Ua Haumene from 1862, became synonymous amongst European New Zealanders with violent resistance but had been established on peaceful principles, as signified by its name, 'Te Hau' meaning 'the breath of God', and 'pai marire' meaning 'peaceful and good'.

743-4 pipi wharuroa ... head 'Pipiwharauroa' (chrysocossyx lucidas), the shining cuckoo, traditionally considered a herald of spring. 
[f. 82v]

Tea

Lunch

wire

milk

wire

wire $\begin{array}{lll}2 & 5 & 0\end{array}$

3

20

6

10

6

$71 / 2$
755

760

$\underline{1 / 2 \mathrm{lb}}$ flour

$\underline{1 / 4 \mathrm{lb}}$ sugar

$\underline{1 / 4 \mathrm{lb}}$ walnuts

$\underline{2}$ eggs

1 teaspoonful baking powder

$\underline{1 / 4 \mathrm{lb}}$ of butter -

Bake in a moderate oven for about 20 minutes. Mrs Webber -

\section{[f. 83]}

\begin{tabular}{rl} 
& 3 \\
2 & 0 \\
& 6 \\
1 & 0 \\
& 6 \\
& $71 / 2$ \\
& $61 / 2$ \\
12 & 0 \\
1 & 6 \\
1 & 3 \\
1 & 6 \\
1 & 0 \\
& 9 \\
1 & 0 \\
& $71 / 2$ \\
3 & 9 \\
3 & 4 \\
2 & 0 \\
3 & 0 \\
& 2 \\
\hline 137. & $71 / 2$
\end{tabular}

\section{[f. 83v] K. Mansfield}

[f. 84] Julian Mark

790 Julian Mark] S, om. G;

788 £1. 137. 71/2 The correct answer based on KM's figures is $£ 1-17-31 \frac{1}{2}$.

790 Julian Mark A pseudonym KM assumed for the stories 'In the Botanical Gardens' published in
The Native Companion in December 1907 and 'In Summer' (S, 176) an unpublished piece written at the same period. Also used as a playful conclusion to a 1908 letter to her sister Vera (O’SS1, 44). 


\section{Appendix}

This letter is neatly written on pages clearly torn from the 'Urewera Notebook'. It was probably detached from the fourth quire, and filled the leaves once between folios 30 and 31. It is completed and folded as if for insertion into an envelope, but was never sent: it fell into Murry's possession following Mansfield's death and was included in the Alexander Turnbull Library's 1954 acquisition of Mansfield papers.

[MS-Papers-4026]

[f. 1]

Waipunga Riverside

Wednesday -

Dear my Mother -

I wrote you my last letter on Monday - and posted it at Pohui in the afternoon - I continue my doings - We drove on through sheep country - to Pohui that night - past Maori 'pahs' and nothing else - and pitched our camp at the top of a bare hill above the Pohui Accomodation House - kept by a certain Mr Bodley - a great pa-man with 14 daughters who sit \& shell peas all day! Below the hill - there was a great valley - and the bush I cannot describe It is the [f. 1v] entrance to the Ahurakura Station - and though we were tired $\&$ hungry Millie, $\mathrm{M}^{\mathrm{rs}}$ Webber \& I dived down a bridle track - and followed the bush - The tuis really sounded like rivers running - everywhere the trees hung wreathed with clematis - and rata and miseltoe - It was very cool \& we washed in a creek - the sides all smothered in daisies - the ferns every where, and eventually came to the homestead - It is a queer spot - ramshackle \& hideous, but the garden is gorgeous - A Maori girl - with her hair in two long braids, sat at [f. 2] the doorstep - shelling peas $-\&$ while we were talking to her - the owner came \& offered to show us the shearing sheds - You know the sheep sound like a wave of the sea - you can hardly hear yourself speak. He took us through it all - they had only two white men working - and the Maoris have a most strange

12 bridle] S, terrible G; 21 know] S, think G;

3 Mother Annie Burnell Beauchamp née Dyer (1864-1918) had married KM's father, Harold Beauchamp, in 1884.

9 pa man A Beauchamp family expression of which KM was especially fond. According to the daughter of KM's cousin, Elizabeth Von Arnim, the term suggested a 'dominant individual, endowed with a highly independent nature, much common sense, a large benevolence and a tendency to express himself in apothegms' (de Charms, 9).

11 ff. On the first three lines of $\mathrm{f} .1 \mathrm{v}$, appear the words: $\quad[$ turanga kuma-

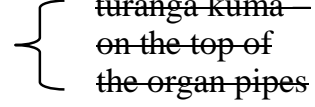

15 rata Metrosideros robusta, a tall forest tree bearing flowers formed of sprays of scarlet stamens. 
bird like call as they hustle the sheep - When we came home it was quite dark \& how I slept -

Next morning at five we were up \& working - and really looking back at yesterday I cannot believe that I have not been to a prodigious biograph show - We drove down the Titi - o 'Kura -and the road is [f. 2v] one series of turns - a great abyss each side of you - and ruts so deep - that you rise three feet in the air - scream \& descend as though learning to trot - It poured with rain early - but then the weather was very clear \& light - with a fierce wind in the mountains - We got great sprays of clematis - and Konini, and drove first through a bush path - But the greatest sight I have seen was the view from the top of Taranga - Kuma - You draw rein at the top of the mountains \& round you everywhere are other mountains - bush covered $-\&$ far below in the valley little Tarawera $\&$ a silver ribbon of river - [f. 3] I could do nothing but laugh - it must have been the air $-\&$ the danger -

We reached the Tarawera Hotel in the evening - \& camped in a little bush hollow -

Grubby, my dear, I felt dreadful - my clothes were white with dust - we had accomplished 8 miles of hill climbing - So after dinner (broad beans cooked over a camp fire and tongue \& cake and tea -) we prowled round and found an "agèd aged man" with had the key of the mineral baths - I wrapt clean clothes in my towel $-\&$ the old man rushed home to seize a [f. $\mathbf{3 v}$ ] candle in a tin - He guided us through the bush track - by the river - \& my dear I've never seen such a cure - I don't think he ever had possessed a tooth \& he never ceased talking - you know the effect?

The Bath House is a shed - three of us bathed in a great pool - waist high - and we of course - in our nakeds - The water was very hot \& like oil - most delicious - We swam - \& soaped \& swam \& soaked $\&$ floated $-\&$ when we came out each drank a great mug of [several illegible letters crossed out] mineral water - luke warm \& tasting like Miss Wood's eggs at their worst stage - But [f. 4] you feel inwardly \& outwardly like velvet - - This morning we walked most of the journey - and in one place met a most fascinating Maori -

32 light] S, bright G; 33 first] S, just G; $\mathbf{5 3}$ \& soaped] S, I soaped G;

28 biograph A trade name for an early projection apparatus, first demonstrated in New York City in 1896 and popular in Wellington by 1907.

33 Konini Fuchsia excorticate, a tree fuchsia which bears purple pendant flowers and succulent blackish berries called 'konini': the name for the fruit is often erroneously used for the tree itself.

45 agèd aged man The White Knight's verse in Lewis Carroll's Through the Looking Glass begins: 'I'll tell thee everything I can; / There's little to relate. / I saw an aged aged man, / A-sitting on a gate.'
49 cure Nineteenth century slang for 'an eccentric'. Four years previously, in a letter written in England, KM had described the London bus drivers as 'such cures' (O'SS1, 4).

56 Miss Wood's eggs A recollection of meals at Queen's College, London, where KM boarded between 1903 and 1906 under the charge of Miss Clara Wood. 58 one place ... Maori The encounter possibly occured at Te Ngakau o Hine Ruku, an historic pa site and early twentieth century Maori settlement, midway between the Waipunga River and Rangitaiki. 
an old splendid man - He took $M^{\text {Is }}$ Webber $\&$ me to see his 'wahine' $-\&$ child - It is a tropical day - the woman squatted in front of the whare - she, too, was very beautiful - strongly Maori - \& when we had shaken hands - she unwrapped her offspring from under two mats $-\&$ held it on her knee - The child wore a little red frock \& a tight bonnet - such a darling thing - I wanted it for a doll - but in a perfect bath of perspiration [f. 4v] Mother couldn't speak a word of English \& I had a great pantomime -

Kathleen - pointing to her own teeth \& then to the baby's - "Ah!" Mother - very appreciative "Ai”"!

Kathleen - pointing to the baby's long curling eyelashes " $\underline{\mathrm{Oh}}$ !"

Mother - most delighted "Aii" -

And so on -

I jumped the baby up \& down in the air - and it crowed with laughter - \& the Mother \& Father - beaming - shook hands with me again Then we drove off - waving until out of sight - all the Maoris do that - Just before pulling up for lunch we came to the Waipunga Falls - my first experience of great waterfalls - [f. 5] they are indescribably beautiful - three - one beside the other $-\&$ a ravine of bush either side - The noise is like thunder $\&$ the sun shone full on the water - I am sitting now on the bank of the river - just a few bends away - the water is flowing past - and the manuka flax \& fern line the banks -

Must go in - goodbye - dear - Tell Jeanne I saw families of wild pigs $\underline{\underline{\&}}$ horses here $-\&$ that we have five horses - such dear old things. They nearly ate my head through the tent last night. I am still bitten $\&$ burnt - but oil of camphor - Solomon solution - glycerine $\&$ cucumber $-[\mathbf{f} . \mathbf{5 v}]$ rose water - are curing me $-\&$ I keep wrapt in a motor veil. This is the way to travel - it is so slow \& so absolutely free - and I'm quite fond of all the people - they are ultra-Colonial but thoroughly kind \& good hearted \& generous - and always more than good to me - We sleep tonight at the Rangitaiki \& then the plains \& the back blocks -

Love to everybody - I am very happy -

Your daughter

Kathleen.

Later Posting at country shed - can't buy envelopes - Had wonderful dinner of tomatoes - Ah! he's given me an hotel envelope. K.

59 wahine Ma. woman, wife.

85 Solomon solution A panacea for all skin irritations, distributed from Melbourne. 


\section{Bibliography}

\section{Edited works of Katherine Mansfield}

Mansfield, Katherine, The Dove's Nest, and Other Stories, ed. by John Middleton Murry (London: Constable, 1923)

_ Journal of Katherine Mansfield 1904-1922: Definitive Edition, ed. by John Middleton Murry (London: Hutchinson, 1954)

Undiscovered Country: The New Zealand Stories of Katherine Mansfield, ed. by Ian

A. Gordon (London: Longman, 1974)

The Urewera Notebook, ed. by Ian A. Gordon (Oxford; New York: Oxford University Press, 1978)

- The Collected Letters of Katherine Mansfield, ed. by Vincent O'Sullivan and Margaret Scott, 5 vols (Oxford: Clarendon Press, 1984) 1

New Zealand Stories, ed. by Vincent O'Sullivan (Auckland: Oxford University Press, 1997)

The Katherine Mansfield Notebooks, ed. by Margaret Scott (Lincoln; Wellington: Lincoln University Press and Daphne Brasell Associates, 1997)

— Selected Stories, ed. by Angela Smith (Oxford; New York: Oxford University Press, 2002)

- The Collected Fiction of Katherine Mansfield, ed. by Gerri Kimber and Vincent O'Sullivan, 2 vols (Edinburgh: Edinburgh University Press, 2012) 1

- The Collected Fiction of Katherine Mansfield, ed. by Gerri Kimber and Vincent O'Sullivan, 2 vols (Edinburgh: Edinburgh University Press, 2012) 2

\section{Manuscripts and oral histories}

Wellington, Alexander Turnbull Library, qMS-1244, Notebook 2 
Wellington, Alexander Turnbull Library, MS-Papers-4026, Beauchamp, Lady Annie Burnell (Dyer) 1864-1918 Letter from Kathleen Beauchamp

Wellington, Alexander Turnbull Library, MSY-4600, New Zealand Journals/Dudley Alexander

Wellington, Alexander Turnbull Library, MS-Papers-4010, Elsie Webber to Henry Graydon Cook, 20 February 1956

Wellington, Alexander Turnbull Library, MS-Papers-7224-06, Will of Katherine Mansfield Murry

Wellington, Alexander Turnbull Library, MS-Papers-1339, Marion C. Ruddick 'Incidents in the Childhood of Katherine Mansfield'

Wellington, Alexander Turnbull Library, MS-Papers-6498, Eric Ramsden to Pat Lawlor, 1949

Wellington, Alexander Turnbull Library, MS-Papers-7293-12, George Ebbett to P A Lawlor, 3 March 1957

Wellington, Alexander Turnbull Library, MS-Papers, 6984-27, Andrew B.M. Bell to Ian A. Gordon, 18 November 1975

Wellington, Alexander Turnbull Library, MS-Papers-6425, Scott, Margaret. Papers re research on Katherine Mansfield

Wellington, Alexander Turnbull Library, MS-Papersp-3981-007, Harold Beauchamp to G.N. Morris, 6 December 1937

Hastings, Ebbett Collection, Hastings District Libraries, Ebbett, George, Notes on Early Hastings, N. d. TS

Wellington, New Zealand Parliamentary Library, Parliamentary Library Daybook Wellington, Alexander Turnbull Library, MS-Papers-6984-27, Jeanne Renshaw to Ian A. Gordon, 21 August 1997, and Jeanne Renshaw to Ian A. Gordon, 19 January 1978 Archives New Zealand, Department of Education, Northern Regional Office (BAAA), Maori Schools - Register of Daily Attendance - Te Whaiti, Series 1006 
Wellington, Oral History Centre at the Alexander Turnbull Library, OHC003422, Interview with Three Sisters of Katherine Mansfield, 1962

Hawke's Bay, Hawke's Bay Cultural Trust/Ruawharo Ta-u-Rangi, Ebbett Collection Display Panel

\section{Personal communications}

Bird, Pem, Personal communication (3-6 November, 2013)

Bland, Dr Kyle, Personal communication (29 July 2013)

Mason, Te Haumihiata, Personal communication (9 December 2013)

Warbrick, Dr Paerau, Personal communication (27 June-11 July 2013)

\section{Government documents}

Appendices to the Journals of the House of Representatives, 1906, I H-31

Appendices to the Journals of the House of Representatives, 1907, I H-31

Appendices to the Journals of the House of Representatives, 1908, I C-01a

Appendices to the Journals of the House of Representatives, 1908, I D-01

Results of a Census of the Colony of New Zealand Taken for the Night of the 29th April, 1906: <http://www3.stats.govt.nz/historic_publications/1906-census/1906-resultscensus/1906-results-census.html> [accessed 15 April 2014]

The New Zealand Official Year-Book 1907:

<http://www3.stats.govt.nz/New_Zealand_Official_Yearbooks/1907/NZOYB_1907.html> [accessed 15 April 2014]

Waitangi Tribunal, The Pouakani Report (Wai 33, 1993)

Waitangi Tribunal, The Mohaka ki Ahuriri Report (Wai 201, 2004) 1

Waitangi Tribunal, The Mohaka ki Ahuriri Report (Wai 201, 2004) 2 


\section{Other primary sources}

Blanche Baughan, Single-short and other verses (Christchurch: Witcombe and Tombs, 1908)

The Cyclopedia of New Zealand: Industrial, Descriptive, Historical, Biographical Facts, Figures, Illustrations, 6 vols (Wellington: Cyclopedia Co., 1902) 2

Fletcher, Henry James, 'A Few of the Maori Wise Sayings From Lake Taupo’, The Journal of the Polynesian Society, 31.1 (1922) 29-36

Sargar, Keith and James T. Boulton, eds, The Cambridge Edition of the Letters of D.H. Lawrence, 7 vols (Cambridge: Cambridge University Press, 1979), VII

\section{Secondary sources}

Alpers, Antony, Katherine Mansfield: A Biography (London: Cape, 1954)

Atkinson, Neill, Trainland: How Railways Made New Zealand. (Auckland: Random House, 2007)

Beauchamp, Harold, Reminiscences and Recollections (New Plymouth, NZ: T. Avery, 1937)

Bell, James Mackintosh, The Wilds of Maoriland (London: Macmillan, 1914)

Berkman, Sylvia, Katherine Mansfield: A Critical Study (New Haven, CN: Yale University Press, 1951)

Binney, Judith, Redemption Songs: A Life of Te Kooti Arikirangi Te Turuki (Auckland: Auckland University Press and Bridget Williams Books, 1995)

_ Encircled Lands: Te Urewera, 1820-1921. (Wellington: Bridget Williams Books, 2009)

Stories Without End: Essays 1975-2010. (Wellington: Bridget Williams Books, 2010)

Bird, Henry Tahawai, Kuranui-O Ngati Manawa (Rotorua: Rotorua Printers, 1980) 
Boast, Richard, Buying the Land, Selling the Land: Governments and Maori Land in the North Island 1865-1921 (Wellington: Victoria University Press and Victoria University of Wellington Law Review, 2008)

Boyd, Mary Beatrice, City of the Plains: A History of Hastings. (Wellington: Victoria University Press for Hastings City Council, 1984)

Boyd, Joan, Pumice and Pines: The Story of the Kaingaroa Forest (Wellington: GP Publications, 1992)

Brown, Deidre, Maori Architecture: From Fale to Wharenui and Beyond (Auckland: Raupo, 2009)

Buzard, James, 'The Grand Tour and After, 1660-1840', in Peter Hulme, ed., The Cambridge Companion to Travel Writing (Cambridge, UK; New York: Cambridge University Press, 2002)

Coutts, Brian and Don Grant, 'The New Zealand Surveyor - The Twenty-first Century', Strategic Integration of Surveying Services: Fédération Internationale des Géomètres Working Week (Hong Kong: 13-17 May 2007) Conference Proceedings

Cowan, James, New Zealand or Ao-tea-roa: Wealth and Resources, Scenery, Travel-Routes, Spas, and Sport (Wellington: John Mackay, Government Printer, 1908)

Crowe, Andrew, Which Native Tree? New Zealand Native Trees: A Simple Guide to their Identification, Ecology and Uses. (Auckland: Penguin, 2009)

De Charms, Leslie. Elizabeth of the German Garden (London, Heinemann, 1958)

Duranti, Alessandro, Linguistic Anthropology (New York: Cambridge University Press, 1997)

Elkington, E. Way, Adrift in New Zealand (London: John Murray, 1906)

Ell, Gordon, Rotorua: Text and Pictures (Auckland: Bush Press, 1995)

Frow, John, Time and Commodity Culture: Essays in Cultural Theory and Postmodernity (Oxford: Clarendon Press, 1997) 
Gordon, Ian A., 'Katherine Mansfield in the Late Twentieth Centry', in Paulette Michel and Michel Dupuis, eds, The Fine Instrument: Essays on Katherine Mansfield (Sydney: Dangaroo Press, 1989), pp. 15-27

Gordon, Ian A., 'The Editing of Katherine Mansfield's Journal and Scrapbook', in Jan Pilditch, ed., The Critical Response to Katherine Mansfield (Westport, CT: Greenwood Press, 1996), pp. 77-82

Historical Affairs Committee at the Hawke's Bay and East Coast Museum, Napier, 18551955: One Hundred Years on the Napier-Taupo Road (Napier: Venables, 1956)

Holroyd, Michael, Lytton Strachey: The New Biography (New York: Norton, 1994) Jackson, Anna, 'The Notebooks, Journal and Papers of Katherine Mansfield: Is Any of this her Diary?' Journal of New Zealand Literature, 18-19 (2001), 83-99

Jones, Kathleen, Katherine Mansfield: The Story-teller (Auckland: Viking, 2010)

Keam, Ron, 'Warbrick, Alfred Patchett', in Te Ara, The Encyclopedia of New Zealand, $<$ http://www.TeAra.govt.nz/en/biographies/2w7/warbrick- alfred- patchett> [accessed 30 October 2013]

King, Michael, The Penguin History of New Zealand (Auckland: Penguin, 2003)

King, Michael, 'Ramsden, George Eric Oakes', in Te Ara, The Encyclopedia of New Zealand, <http://www.TeAra.govt.nz/en/biographies/4r1/ramsden-george-eric-oakes> [accessed 14 January 2014]

Majumdar, Saikat, Prose of the World: Modernism and the Banality of Empire (New York: Columbia University Press, 2013)

Mantz, Ruth Elvish, and John Middleton Murry, The Life of Katherine Mansfield (London: Constable, 1933)

Maxwell, Anne, 'A Young Writer's Journey into the New Zealand Interior: Katherine Mansfield's The Urewera Notebook', in Tim Youngs, ed., Travel Writing in the Nineteenth Century: Filling the Blank Spaces (Singapore: Anthem Press, 2006)

McClure, Margaret, The Wonder Country: Making New Zealand Tourism (Auckland: Auckland University Press, 2004) 
McGarvey, Rangi, 'Ngai Tuhoe', in Te Ara, Encyclopedia of New Zealand, <http://www.TeAra.govt.nz/en.ngai-tuhoe> [accessed 16 April 2014]

Mead, Hirini Moko and Neil Grove, Nga Pepeha a nga Tipuna - The Sayings of the Ancestors (Wellington: Victoria University Press, 2001)

Meyers, Jeffrey, Katherine Mansfield: A Biography (London: Hamish Hamilton, 1978)

Moon, Paul, Encounters: The Creation of New Zealand: A History (Auckland: Penguin, 2013)

Murry, John Middleton, 'The Weariness of Ivan Bunin’, Dial, 76 (1924), 194-7

O'Malley, Vincent, and David Anderson Armstrong, The Beating Heart: A Political and Socio-economic History of Te Arawa (Wellington: Huia, 2008)

Orsman, Harry ed., The Dictionary of New Zealand English: A Dictionary of New Zealandisms on Historical Principles (Auckland, Oxford University Press, 1997)

Parsons, Patrick, In the Shadow of Te Waka: The History of the Te Pohue District (Napier: Te Pohue History Committee, 1997)

Phillipps, William John, The Book of the Huia (Christchurch: Whitcombe and Tombs, 1963) Pratt, Mary Louise, Imperial Eyes: Travel Writing and Transculturation (London and New York: Routledge, 2008)

Reed, Alfred Hamish, The Story of Hawke’s Bay (Dunedin: Reed, 1958)

Ricketts, Harry, 'John Middleton Murry: Keeper of the Flame' in Charles Ferrall and Jane Stafford, eds, Katherine Mansfield's Men (Wellington: Katherine Mansfield Birthplace Society and Steele Roberts, 2004)

Scott, Margaret, Recollecting Mansfield (Auckland: Godwit, 2001)

Smith, Angela, Katherine Mansfield and Virginia Woolf: A Public of Two (New York: Clarendon Press, 1999)

Stafford, Don, The New Century in Rotorua: A History of Events from 1900 (Auckland; Rotorua: Ray Richards Publisher and Rotorua District Council, 1988) 
Stafford, Jane and Mark Williams, Maoriland: New Zealand Literature, 1872-1914

(Wellington: Victoria University Press, 2006)

Star, Paul and Lynne Lochhead, 'Children of the Burnt Bush: New Zealand and the Indigenous Remnant, 1880-1930', in Making a New Land: Environmental Histories of New Zealand, ed. by Eric Pawson and Tom Brooking (Dunedin: University of Otago Press, 2003) pp. 119-135

Stead, C.K., 'Meetings with 'the Great Ghost', in Gerri Kimber and Janet Wilson, eds, Celebrating Katherine Mansfield: A Centenary Volume of Essays (Basingstoke: Palgrave Macmillan, 2011)

Tomalin, Claire, Katherine Mansfield: A Secret Life (London: Viking, 1987)

Urry, John and Jonas Larsen, The Tourist Gaze 3.0 (London: Sage, 2011)

Waldron, Philip, 'Katherine Mansfield's Journal, Twentieth Century Literature, 20 (1974), $11-18$

Werry, Margaret, The Tourist State: Performing Leisure, Liberalism and Race in New Zealand (Minneapolis: Quadrant, 2001)

Wevers, Lydia, Country of Writing: Travel Writing and New Zealand 1809-1900 (Auckland: Auckland University Press, 2002)

Wilson, Janet, and others, eds, Katherine Mansfield and Literary Modernism (London: Continuum, 2001) 